Cochrane Database of Systematic Reviews

\title{
Holding chambers (spacers) versus nebulisers for beta-agonist treatment of acute asthma (Review)
}

Cates CJ, Welsh EJ, Rowe BH

Cates CJ, Welsh EJ, Rowe BH.

Holding chambers (spacers) versus nebulisers for beta-agonist treatment of acute asthma.

Cochrane Database of Systematic Reviews 2013, Issue 9. Art. No.: CD000052.

DOI: 10.1002/14651858.CD000052.pub3.

www.cochranelibrary.com 
TABLE OF CONTENTS

HEADER 1

ABSTRACT

PLAIN LANGUAGE SUMMARY

SUMMARY OF FINDINGS

BACKGROUND

OBJECTIVES

METHODS

RESULTS

Figure 1.

Figure 2.

Figure 3.

Figure 4.

Figure 5.

Figure 6.

DISCUSSION

AUTHORS' CONCLUSIONS

ACKNOWLEDGEMENTS

REFERENCES

CHARACTERISTICS OF STUDIES

DATA AND ANALYSES

Analysis 1.1. Comparison 1 Spacer (chamber) versus nebuliser (multiple-treatment studies), Outcome 1 Hospital admission. ..

Analysis 1.2. Comparison 1 Spacer (chamber) versus nebuliser (multiple-treatment studies), Outcome 2 Hospital admission or poor response to treatment.

Analysis 1.3. Comparison 1 Spacer (chamber) versus nebuliser (multiple-treatment studies), Outcome 3 Duration in emergency department (minutes).

Analysis 1.4. Comparison 1 Spacer (chamber) versus nebuliser (multiple-treatment studies), Outcome 4 Final rise in FEV ${ }_{1} \%$ predicted).

Analysis 1.5. Comparison 1 Spacer (chamber) versus nebuliser (multiple-treatment studies), Outcome 530 minute rise in FEV (\% predicted).

Analysis 1.6. Comparison 1 Spacer (chamber) versus nebuliser (multiple-treatment studies), Outcome 6 Severe asthmatics final rise in $\mathrm{FEV}_{1}$ (\% predicted).

Analysis 1.7. Comparison 1 Spacer (chamber) versus nebuliser (multiple-treatment studies), Outcome 7 Final rise in peak flow (\% predicted).

Analysis 1.8. Comparison 1 Spacer (chamber) versus nebuliser (multiple-treatment studies), Outcome 830 minute rise in peak flow (\% predicted).

Analysis 1.9. Comparison 1 Spacer (chamber) versus nebuliser (multiple-treatment studies), Outcome 9 Rise in pulse rate (\% baseline).

Analysis 1.10. Comparison 1 Spacer (chamber) versus nebuliser (multiple-treatment studies), Outcome $10 \%$ Oxygen saturation (change from baseline).

Analysis 1.11. Comparison 1 Spacer (chamber) versus nebuliser (multiple-treatment studies), Outcome 11 Number of participants developing tremor.

Analysis 1.12. Comparison 1 Spacer (chamber) versus nebuliser (multiple-treatment studies), Outcome 12 Number of participants given steroids.

Analysis 1.13. Comparison 1 Spacer (chamber) versus nebuliser (multiple-treatment studies), Outcome 13 Rise in respiratory rate (breaths per minute).

Analysis 2.1. Comparison 2 Spacer (chamber) versus nebuliser (single-treatment studies), Outcome 1 Hospital admission. .... Analysis 2.2. Comparison 2 Spacer (chamber) versus nebuliser (single-treatment studies), Outcome 2 Final peak flow (\% predicted).

Analysis 2.3. Comparison 2 Spacer (chamber) versus nebuliser (single-treatment studies), Outcome 330 minute rise in FEV (\% predicted).

Analysis 2.4. Comparison 2 Spacer (chamber) versus nebuliser (single-treatment studies), Outcome 415 minute rise in FEV (\% predicted).

Analysis 2.5. Comparison 2 Spacer (chamber) versus nebuliser (single-treatment studies), Outcome 530 minute rise in peak flow (\% predicted). 
Analysis 2.6. Comparison 2 Spacer (chamber) versus nebuliser (single-treatment studies), Outcome 615 minute rise in peak flow (\% predicted).

Analysis 2.7. Comparison 2 Spacer (chamber) versus nebuliser (single-treatment studies), Outcome 7 Rise in pulse rate (\% baseline).

Analysis 2.8. Comparison 2 Spacer (chamber) versus nebuliser (single-treatment studies), Outcome 8 Number of participants developing tremor.

Analysis 2.9. Comparison 2 Spacer (chamber) versus nebuliser (single-treatment studies), Outcome 9 Number of participants with deterioration in blood gases.

Analysis 2.10. Comparison 2 Spacer (chamber) versus nebuliser (single-treatment studies), Outcome 10 Rise in respiratory rate.

Analysis 3.1. Comparison 3 Spacer (chamber) versus nebuliser (inpatient studies), Outcome 1 Duration of hospital admission (days).

Analysis 3.2. Comparison 3 Spacer (chamber) versus nebuliser (inpatient studies), Outcome 2 Number of hours until reached 4-hourly dosing regimen.

Analysis 3.3. Comparison 3 Spacer (chamber) versus nebuliser (inpatient studies), Outcome 3 Total number of inhaled doses received.

Analysis 3.4. Comparison 3 Spacer (chamber) versus nebuliser (inpatient studies), Outcome 4 Number of participants returning to normal PEFR and respiratory score levels (end of study).

Analysis 3.5. Comparison 3 Spacer (chamber) versus nebuliser (inpatient studies), Outcome 5 Number of symptom-free participants 14 days post-discharge.

Analysis 3.6. Comparison 3 Spacer (chamber) versus nebuliser (inpatient studies), Outcome 6 Readmissions in the subsequent 12 months.

Analysis 3.7. Comparison 3 Spacer (chamber) versus nebuliser (inpatient studies), Outcome 7 Clinical asthma score (end of trial).

Analysis 3.8. Comparison 3 Spacer (chamber) versus nebuliser (inpatient studies), Outcome 8 Maximum percentage decrease in respiratory score.

Analysis 3.9. Comparison 3 Spacer (chamber) versus nebuliser (inpatient studies), Outcome 9 Respiratory rate at discharge. .. Analysis 3.10. Comparison 3 Spacer (chamber) versus nebuliser (inpatient studies), Outcome 10 Heart rate at discharge. ....... Analysis 3.11. Comparison 3 Spacer (chamber) versus nebuliser (inpatient studies), Outcome 11 Oxygen saturations at discharge.

Analysis 3.12. Comparison 3 Spacer (chamber) versus nebuliser (inpatient studies), Outcome 1230 minute rise in FEV ${ }_{1}$. .........

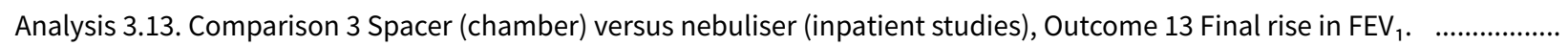
Analysis 3.14. Comparison 3 Spacer (chamber) versus nebuliser (inpatient studies), Outcome 14 Final rise in peak flow (\% change from baseline).

Analysis 4.1. Comparison 4 Spacer (chamber) versus nebuliser (multiple-treatment studies with Volumatic subgroups), Outcome 1 Hospital admission.

Analysis 4.2. Comparison 4 Spacer (chamber) versus nebuliser (multiple-treatment studies with Volumatic subgroups), Outcome 2 Hospital admission or poor response to treatment.

Analysis 4.3. Comparison 4 Spacer (chamber) versus nebuliser (multiple-treatment studies with Volumatic subgroups), Outcome 3 Duration in emergency department (minutes)..

Analysis 4.4. Comparison 4 Spacer (chamber) versus nebuliser (multiple-treatment studies with Volumatic subgroups), Outcome 4 Final rise in $\mathrm{FEV}_{1}$ (\% predicted).

Analysis 4.5. Comparison 4 Spacer (chamber) versus nebuliser (multiple-treatment studies with Volumatic subgroups), Outcome 530 minute rise in $\mathrm{FEV}_{1}$ (\% predicted).

Analysis 4.6. Comparison 4 Spacer (chamber) versus nebuliser (multiple-treatment studies with Volumatic subgroups), Outcome 6 Severe asthmatics final rise in $\mathrm{FEV}_{1}$ (\% predicted).

Analysis 4.7. Comparison 4 Spacer (chamber) versus nebuliser (multiple-treatment studies with Volumatic subgroups), Outcome 7 Final rise in peak flow (\% predicted).

Analysis 4.8. Comparison 4 Spacer (chamber) versus nebuliser (multiple-treatment studies with Volumatic subgroups), Outcome 830 minute rise in peak flow (\% predicted).

Analysis 4.9. Comparison 4 Spacer (chamber) versus nebuliser (multiple-treatment studies with Volumatic subgroups), Outcome 9 Rise in pulse rate (\% baseline). 
[Intervention Review]

\title{
Holding chambers (spacers) versus nebulisers for beta-agonist treatment of acute asthma
}

\author{
Christopher J Cates ${ }^{1}$, Emma J Welsh ${ }^{1}$, Brian H Rowe 2,3
}

1Population Health Research Institute, St George's, University of London, London, UK. 2Department of Emergency Medicine, University of Alberta, Edmonton, Canada. ${ }^{3}$ School of Public Heath, University of Alberta, Edmonton, Canada

Contact address: Christopher J Cates, Population Health Research Institute, St George's, University of London, Cranmer Terrace, London, SW170RE, UK. ccates@sgul.ac.uk.

Editorial group: Cochrane Airways Group

Publication status and date: Edited (no change to conclusions), published in Issue 6, 2014.

Citation: Cates CJ, Welsh EJ, Rowe BH. Holding chambers (spacers) versus nebulisers for beta-agonist treatment of acute asthma. Cochrane Database of Systematic Reviews 2013, Issue 9. Art. No.: CD000052. DOI: 10.1002/14651858.CD000052.pub3.

Copyright @ 2014 The Cochrane Collaboration. Published by John Wiley \& Sons, Ltd.

\section{A B S T R A C T}

\section{Background}

In acute asthma inhaled beta $_{2}$-agonists are often administered by nebuliser to relieve bronchospasm, but some have argued that metereddose inhalers with a holding chamber (spacer) can be equally effective. Nebulisers require a power source and need regular maintenance, and are more expensive in the community setting.

\section{Objectives}

To assess the effects of holding chambers (spacers) compared to nebulisers for the delivery of beta ${ }_{2}$-agonists for acute asthma.

\section{Search methods}

We searched the Cochrane Airways Group Trial Register and reference lists of articles. We contacted the authors of studies to identify additional trials. Date of last search: February 2013.

\section{Selection criteria}

Randomised trials in adults and children (from two years of age) with asthma, where spacer beta ${ }_{2}$-agonist delivery was compared with wet nebulisation.

\section{Data collection and analysis}

Two review authors independently applied study inclusion criteria (one review author for the first version of the review), extracted the data and assessed risks of bias. Missing data were obtained from the authors or estimated. Results are reported with $95 \%$ confidence intervals (Cls).

\section{Main results}

This review includes a total of 1897 children and 729 adults in 39 trials. Thirty-three trials were conducted in the emergency room and equivalent community settings, and six trials were on inpatients with acute asthma (207 children and 28 adults). The method of delivery of beta ${ }_{2}$-agonist did not show a significant difference in hospital admission rates. In adults, the risk ratio (RR) of admission for spacer versus nebuliser was 0.94 ( $95 \% \mathrm{Cl} 0.61$ to 1.43 ). The risk ratio for children was 0.71 ( $95 \% \mathrm{Cl} 0.47$ to 1.08 , moderate quality evidence). In children, length of stay in the emergency department was significantly shorter when the spacer was used. The mean duration in the emergency department for children given nebulised treatment was 103 minutes, and for children given treatment via spacers 33 minutes less ( $95 \% \mathrm{Cl}-43$ to -24 minutes, moderate quality evidence). Length of stay in the emergency department for adults was similar for the two delivery methods. Peak flow and forced expiratory volume were also similar for the two delivery methods. Pulse rate was lower for spacer 
in children, mean difference $-5 \%$ baseline $(95 \% \mathrm{Cl}-8 \%$ to $-2 \%$, moderate quality evidence), as was the risk of developing tremor (RR 0.64 ; $95 \% \mathrm{Cl} 0.44$ to 0.95 , moderate quality evidence).

\section{Authors' conclusions}

Nebuliser delivery produced outcomes that were not significantly better than metered-dose inhalers delivered by spacer in adults or children, in trials where treatments were repeated and titrated to the response of the participant. Spacers may have some advantages compared to nebulisers for children with acute asthma. The studies excluded people with life-threatening asthma; therefore, the results of this meta-analysis should not be extrapolated to this patient population.

\section{PLAIN LANGUAGE SUMMARY}

Holding chambers (spacers) versus nebulisers for delivery of beta-agonist relievers in the treatment of an asthma attack

\section{Review question}

When someone is having an asthma attack is it as safe and effective to use a spacer instead of a nebuliser?

\section{Background}

During an asthma attack, the airways (tubes in the lungs) narrow making breathing difficult. The initial response to an asthma attack is to treat with a drug that can open up the airways and make breathing easier. These drugs are called bronchodilators and in this review we are looking specifically at a class of bronchodilators called beta-agonists (for example salbutamol). These drugs can be taken straight from an inhaler, but during an asthma attack they are easier to take using either a spacer or a nebuliser. A spacer is a hollow chamber. A puff of drug from an inhaler is added to the chamber and then the person breathes in and out normally (also described as tidal breathing), from a mouthpiece on the chamber. A nebuliser is a machine with a mask that goes over the person's mouth and nose and through which a constant stream of drug and air (or oxygen) is breathed in and out normally.

\section{What evidence did we find?}

We found 39 clinical trials involving 1897 children and 729 adults. Thirty-three of the trials were conducted in an emergency room (or emergency department) and community settings (such as a GP's surgery), and six trials were on inpatients (people in hospital) with acute asthma (207 children and 28 adults). Overall we judged the quality of the evidence to be moderate.

\section{What do the studies tell us?}

Taking beta-agonists through either a spacer or a nebuliser in the emergency department did not make a difference to the number of adults being admitted to hospital, whilst in children we can be fairly confident that nebulisers are not better than spacers at preventing admissions.

In children, the length of stay in the emergency department was significantly shorter when the spacer was used instead of a nebuliser. The average stay in the emergency department for children given nebulised treatment was 103 minutes. Children given treatment via spacers spent an average of 33 minutes less.

In adults, the length of stay in the emergency department was similar for the two delivery methods. However the adult studies were conducted slightly differently which may have made it more difficult to show a difference in the length of stay in the emergency department. Because all the adult studies used a so-called "double-dummy" design, the adults received a spacer AND a nebuliser (either beta-agonist in a spacer and a dummy nebuliser or vice versa) which meant both groups of people were in the emergency department for as long as it took to take both treatments.

Lung function tests were also similar for the two delivery methods in both adults and children. Pulse rate was lower in children taking betaagonists through a spacer (mean difference $-5 \%$ baseline), and there was a lower risk of developing tremor.

\section{Conclusion}

Metered-dose inhalers with a spacer can perform at least as well as wet nebulisation in delivering beta ${ }_{2}$-agonists in children with acute asthma, but we are less certain about the results in adults.

The review is current as of February 2013. 


\section{SUMMARY OF FINDINGS}

Summary of findings for the main comparison. Multiple treatment of beta ${ }_{2}$-agonist via spacer (chamber) compared to nebuliser for children with acute asthma

Multiple treatment of beta ${ }_{2}$-agonist via spacer (chamber) compared to nebuliser for children with acute asthma

Patient or population: children with acute asthma

Settings: Community or Emergency Department

Intervention: Multiple treatments with beta ${ }_{2}$-agonist via spacer (chamber)

Comparison: Multiple treatments with beta ${ }_{2}$-agonist via nebuliser

\begin{tabular}{|c|c|c|c|c|c|c|}
\hline \multirow[t]{3}{*}{ Outcomes } & \multicolumn{2}{|c|}{ Illustrative comparative risks ${ }^{\star}(95 \% \mathrm{Cl})$} & \multirow{3}{*}{$\begin{array}{l}\text { Relative ef- } \\
\text { fect } \\
(95 \% \mathrm{CI})\end{array}$} & \multirow{3}{*}{$\begin{array}{l}\text { No of Partici- } \\
\text { pants } \\
\text { (studies) }\end{array}$} & \multirow{3}{*}{$\begin{array}{l}\text { Quality of the } \\
\text { evidence } \\
\text { (GRADE) }\end{array}$} & \multirow[t]{3}{*}{ Comments } \\
\hline & Assumed risk & Corresponding risk & & & & \\
\hline & Nebuliser & $\begin{array}{l}\text { Multiple treatment of be- } \\
\mathrm{ta}_{2} \text {-agonist via spacer } \\
\text { (chamber) }\end{array}$ & & & & \\
\hline $\begin{array}{l}\text { Hospital ad- } \\
\text { mission }\end{array}$ & 110 per 1000 & $\begin{array}{l}\mathbf{7 8} \text { per } 1000 \\
(52 \text { to } 119)\end{array}$ & $\begin{array}{l}\text { RR 0.71 } \\
\text { (0.47 to } 1.08)\end{array}$ & $\begin{array}{l}757 \\
\text { (9 studies) }\end{array}$ & $\begin{array}{l}\oplus \oplus \ominus \ominus \\
\text { low } 1,2\end{array}$ & $\begin{array}{l}\text { Large increases in the proportion } \\
\text { of children admitted to hospital on } \\
\text { spacer in comparison to nebuliser } \\
\text { are ruled out by this } 95 \% \text { confidence } \\
\text { interval. }\end{array}$ \\
\hline $\begin{array}{l}\text { Duration in } \\
\text { emergency } \\
\text { department } \\
\text { (minutes) }\end{array}$ & $\begin{array}{l}\text { The mean duration in emer- } \\
\text { gency department (minutes) in } \\
\text { the control groups was } \\
\mathbf{1 0 3} \text { minutes }\end{array}$ & $\begin{array}{l}\text { The mean duration in } \\
\text { emergency department } \\
\text { (minutes) in the interven- } \\
\text { tion groups was } \\
\mathbf{3 3} \text { minutes shorter } \\
\text { (43 minutes shorter to } 24 \\
\text { minutes shorter) }\end{array}$ & & $\begin{array}{l}396 \\
\text { (3 studies) }\end{array}$ & $\begin{array}{l}\oplus \oplus \oplus \ominus \\
\text { moderate } 1\end{array}$ & $\begin{array}{l}\text { There was a consistent direction } \\
\text { of shortening of time in ED in all } 3 \\
\text { studies, and although the size of this } \\
\text { effect varied between studies }\left(l^{2}=\right. \\
66 \%) \text {, we felt that the mean differ- } \\
\text { ence was important in all studies. }\end{array}$ \\
\hline $\begin{array}{l}\text { Final rise in } \\
\text { FEV }_{1}(\% \text { pre- } \\
\text { dicted })\end{array}$ & $\begin{array}{l}\text { The mean final rise in } \mathrm{FEV}_{1}(\% \\
\text { predicted) in the control groups } \\
\text { was } \\
\mathbf{2 7 \%} \text { predicted at baseline }\end{array}$ & $\begin{array}{l}\text { The mean final rise in } \mathrm{FEV}_{1} \\
\text { (\% predicted) in the inter- } \\
\text { vention groups was } \\
\mathbf{0 . 9 2} \% \text { higher } \\
\text { (4.96\% lower to } 6.79 \% \\
\text { higher) }\end{array}$ & & $\begin{array}{l}48 \\
\text { ( } 2 \text { studies) }\end{array}$ & $\begin{array}{l}\oplus \oplus \ominus \ominus \\
\text { low }^{1,2}\end{array}$ & \\
\hline $\begin{array}{l}\text { Rise in pulse } \\
\text { rate (\% base- } \\
\text { line) }\end{array}$ & $\begin{array}{l}\text { The mean rise in pulse rate (\% } \\
\text { baseline) in the control groups } \\
\text { was }\end{array}$ & $\begin{array}{l}\text { The mean rise in pulse } \\
\text { rate (\% baseline) in the in- } \\
\text { tervention groups was }\end{array}$ & & $\begin{array}{l}670 \\
\text { (9 studies) }\end{array}$ & $\begin{array}{l}\oplus \oplus \oplus \ominus \\
\text { moderate } 1\end{array}$ & \\
\hline
\end{tabular}

tervention groups was 


\begin{tabular}{|c|c|c|c|c|c|}
\hline \multirow{2}{*}{$\begin{array}{l} \\
\text { Number of } \\
\text { participants } \\
\text { developing } \\
\text { tremor }\end{array}$} & $\mathbf{7 \%}$ rise from baseline & $\begin{array}{l}\mathbf{5 . 6 2} \% \text { lower } \\
\text { (7.52\% to } 3.72 \% \text { lower) }\end{array}$ & & & \\
\hline & 142 per 1000 & $\begin{array}{l}91 \text { per } 1000 \\
(62 \text { to } 135)\end{array}$ & $\begin{array}{l}\text { RR } 0.64 \\
(0.44 \text { to } 0.95)\end{array}$ & $\begin{array}{l}254 \\
\text { (4 studies) }\end{array}$ & $\begin{array}{l}\oplus \oplus \oplus \ominus \\
\text { moderate }{ }^{1}\end{array}$ \\
\hline
\end{tabular}

*The basis for the assumed risk (e.g. the median control group risk across studies) is provided in footnotes. The corresponding risk (and its $95 \%$ confidence interval) is based on the assumed risk in the comparison group and the relative effect of the intervention (and its $95 \% \mathrm{Cl}$ ).

Cl: Confidence interval; RR: Risk ratio;

GRADE Working Group grades of evidence

High quality: Further research is very unlikely to change our confidence in the estimate of effect.

Moderate quality: Further research is likely to have an important impact on our confidence in the estimate of effect and may change the estimate.

Low quality: Further research is very likely to have an important impact on our confidence in the estimate of effect and is likely to change the estimate.

Very low quality: We are very uncertain about the estimate.

1 Mostly open label studies

2 Wide confidence intervals

\section{Summary of findings 2. Multiple treatment of beta ${ }_{2}$-agonist via spacer (chamber) compared to nebuliser for adults with acute asthma}

\section{Multiple treatment of beta $_{2}$-agonist via spacer (chamber) compared to nebuliser for adults with acute asthma}

Patient or population: Adults with acute asthma

Settings: Community or Emergency Department

Intervention: Multiple treatments with beta ${ }_{2}$-agonist via spacer (chamber)

Comparison: Multiple treatments with beta ${ }_{2}$-agonist via nebuliser

\begin{tabular}{|c|c|c|c|c|c|c|}
\hline \multirow[t]{3}{*}{ Outcomes } & \multicolumn{2}{|l|}{ Illustrative comparative risks ${ }^{\star}(95 \% \mathrm{CI})$} & \multirow{3}{*}{$\begin{array}{l}\text { Relative ef- } \\
\text { fect } \\
(95 \% \mathrm{CI})\end{array}$} & \multirow{3}{*}{$\begin{array}{l}\text { No of Partici- } \\
\text { pants } \\
\text { (studies) }\end{array}$} & \multirow{3}{*}{$\begin{array}{l}\text { Quality of the } \\
\text { evidence } \\
\text { (GRADE) }\end{array}$} & \multirow[t]{3}{*}{ Comments } \\
\hline & Assumed risk & Corresponding risk & & & & \\
\hline & Nebuliser & $\begin{array}{l}\text { Multiple treatment of beta }{ }_{2} \text {-ago- } \\
\text { nist via spacer (chamber) }\end{array}$ & & & & \\
\hline $\begin{array}{l}\text { Hospital admis- } \\
\text { sion }\end{array}$ & 109 per 1000 & $\begin{array}{l}\mathbf{1 0 3} \text { per } \mathbf{1 0 0 0} \\
(67 \text { to } 156)\end{array}$ & $\begin{array}{l}\text { RR } 0.94 \\
\text { (0.61 to } 1.43)\end{array}$ & $\begin{array}{l}582 \\
\text { (9 studies) }\end{array}$ & $\begin{array}{l}\oplus \oplus \oplus \ominus \\
\text { moderate } 1,2\end{array}$ & \\
\hline $\begin{array}{l}\text { Duration in emer- } \\
\text { gency department } \\
\text { (minutes). }\end{array}$ & $\begin{array}{l}\text { The mean duration in emergency de- } \\
\text { partment (minutes) in the control } \\
\text { groups was }\end{array}$ & $\begin{array}{l}\text { The mean duration in emergency } \\
\text { department (minutes) in the inter- } \\
\text { vention groups was }\end{array}$ & & $\begin{array}{l}132 \\
\text { (2 studies) }\end{array}$ & $\begin{array}{l}\oplus \oplus \oplus \ominus \\
\text { moderate }^{2}\end{array}$ & \\
\hline
\end{tabular}

(minutes).

groups was vention groups was 


\begin{tabular}{|c|c|c|c|c|c|}
\hline 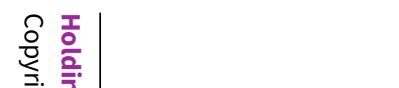 & 109 minutes & $\begin{array}{l}2 \text { minutes longer } \\
\text { ( } 23 \text { minutes shorter to } 27 \text { longer) }\end{array}$ & & & \\
\hline $\begin{array}{l}\text { Final rise in } \\
\operatorname{FEV}_{1}(\% \text { predicted })\end{array}$ & $\begin{array}{l}\text { The mean final rise in } \mathrm{FEV}_{1}(\% \text { predicted }) \\
\text { in the control groups was } \\
\mathbf{2 2} \% \text { predicted } \mathbf{F E V}_{\mathbf{1}}\end{array}$ & $\begin{array}{l}\text { The mean final rise in FEV1 (\% pre- } \\
\text { dicted) in the intervention groups } \\
\text { was } \\
\mathbf{0 . 9 6 \%} \text { higher } \\
\text { ( } 2.54 \text { lower to } 4.46 \text { higher) }\end{array}$ & & $\begin{array}{l}307 \\
\text { (6 studies) }\end{array}$ & $\begin{array}{l}\oplus \oplus \oplus \oplus \\
\text { high }^{3,4}\end{array}$ \\
\hline $\begin{array}{l}\text { Rise in pulse rate } \\
\text { (\% baseline) }\end{array}$ & $\begin{array}{l}\text { The mean rise in pulse rate (\% baseline) } \\
\text { in the control groups was } \\
-\mathbf{- 2} \% \text { of baseline }\end{array}$ & $\begin{array}{l}\text { The mean rise in pulse rate (\% } \\
\text { baseline) in the intervention } \\
\text { groups was } \\
\mathbf{1 . 2 3} \text { lower } \\
\text { ( } 4.06 \text { lower to } 1.6 \text { higher) }\end{array}$ & & $\begin{array}{l}376 \\
\text { (7 studies) }\end{array}$ & $\begin{array}{l}\oplus \oplus \oplus \oplus \\
\text { high }^{3,4}\end{array}$ \\
\hline $\begin{array}{l}\text { Number of partici- } \\
\text { pants developing } \\
\text { tremor }\end{array}$ & 185 per 1000 & $\begin{array}{l}207 \text { per } \mathbf{1 0 0 0} \\
(122 \text { to } 351)\end{array}$ & $\begin{array}{l}\text { RR } 1.12 \\
(0.66 \text { to } 1.9)\end{array}$ & $\begin{array}{l}234 \\
\text { (4 studies) }\end{array}$ & $\begin{array}{l}\oplus \oplus \oplus \ominus \\
\text { moderate } 2,3\end{array}$ \\
\hline
\end{tabular}

*The basis for the assumed risk (e.g. the median control group risk across studies) is provided in footnotes. The corresponding risk (and its $95 \%$ confidence interval) is based on the assumed risk in the comparison group and the relative effect of the intervention (and its $95 \% \mathrm{Cl}$ ).

Cl: Confidence interval; RR: Risk ratio;

GRADE Working Group grades of evidence

High quality: Further research is very unlikely to change our confidence in the estimate of effect.

Moderate quality: Further research is likely to have an important impact on our confidence in the estimate of effect and may change the estimate.

Low quality: Further research is very likely to have an important impact on our confidence in the estimate of effect and is likely to change the estimate.

Very low quality: We are very uncertain about the estimate.

1 Mostly double-blind studies.

2 Confidence intervals too wide to assess whether either treatment is better.

3 All double-blind studies.

4 Very small absolute differences. 


\section{B A C K G R O U N D}

\section{Description of the condition and intervention}

Exacerbations of asthma are common and account for a considerable number of physician encounters, both in hospital and in primary care. In exacerbations the airways become narrowed due to mucosal oedema, hypersecretion and bronchospasm. Depending on the severity of the attack, treatment with inhaled beta ${ }_{2}$-agonists is often required in addition to other agents such as corticosteroids. The use of beta ${ }_{2}$-agonists is intended to relieve the bronchospasm. This is accomplished most effectively when the drug is delivered to the peripheral airways. This is made more difficult in acute asthma since the narrowed airways and faster respiratory rate result in increased drug deposition in the throat and large airways. Consequently, it is less effective and may cause more side effects.

Two different delivery methods have been employed to overcome this problem: wet nebulisations and metered-dose inhalers (MDIs) with a holding chamber (spacer). Nebulisation creates a mist of beta ${ }_{2}$-agonist diluted in saline which is inhaled through a mask by tidal breathing. Nebulisation can be accomplished with room air or supplemental oxygen, and requires a supply of compressed gas or a power source. More recently, beta ${ }_{2}$-agonists delivered via MDIs through a spacer have been used in acute asthma. The drug is released into the spacer by pressing the MDI after it has been shaken and inserted into the spacer (also called 'actuation'). The drug in the spacer is then emptied by the person using either tidal breathing (normal breathing in and out) or a single deep breath.

\section{Why it is important to do this review}

Whilst nebulisers have historically been used in exacerbations of asthma, a meta-analysis of trials in adults with asthma or chronic obstructive pulmonary disease (COPD) suggested that metereddose inhalers with a spacer are as effective (Turner 1997).There has been considerable controversy regarding the merits of each delivery method, but current guidelines have now moved towards the use of spacers in acute asthma, particularly in children (BTS/ SIGN 2011). In addition, cost and infection control considerations may be important additional determinants of which system is employed. For example, in the community the cost of nebulisers exceeds a spacer and MDI. In hospital emergency departments, the cost calculations are more complex since disposable nebuliser masks are often driven by piped oxygen; costs may depend on whether or not all patients are sent home with a new spacer. Nebulisers also represent a potential source of cross-infection, and require regular maintenance. As a result of these controversies, this systematic review has been updated to assess all the available evidence from randomised controlled trials comparing the two delivery methods in adults and children with acute asthma.

\section{O B JE C T IVES}

To assess the effects of holding chambers (spacers) compared to nebulisers for the delivery of beta ${ }_{2}$-agonists for acute asthma.

\section{METHODS}

\section{Criteria for considering studies for this review}

Types of studies

Only randomised controlled trials were considered for this review.

\section{Types of participants}

Adults and children (but not infants) with acute asthma presenting for medical assistance in the community setting or hospital emergency department. Studies describing people who had already been admitted to hospital have been included in this update. Studies of children with a mean age of two years or more were included, as it is difficult to diagnose asthma under this age. Studies of people with asthma and chronic obstructive pulmonary diease (COPD) were included as long as separate results could be obtained for the asthma patients.

\section{Types of interventions}

Any beta ${ }_{2}$-agonist given by any nebuliser versus the same beta ${ }_{2}-$ agonist given by metered-dose inhaler with any spacer. The dose of drug and method of administration must have been recorded. Cointerventions and contamination (cross-over) may have occurred, but these must have been recorded.

\section{Types of outcome measures}

\section{Primary outcomes}

1. Admission to hospital.

2. Duration of hospital stay for inpatients.

\section{Secondary outcomes}

1. Duration in the emergency department.

2. Change in respiratory rate.

3. Blood gases.

4. Pulse rate.

5. Tremor.

6. Symptom score.

7. Lung function.

8. Use of steroids.

9. Relapse rates.

\section{Search methods for identification of studies}

\section{Electronic searches}

We identified trials using the Cochrane Airways Group Specialised Register, which is maintained by the Trials Search Coordinator for the Group. The Register contains trial reports identified through systematic searches of bibliographic databases including the Cochrane Central Register of Controlled Trials (CENTRAL), MEDLINE, EMBASE, CINAHL, AMED and PsycINFO, and handsearching of respiratory journals and meeting abstracts (see Appendix 1 for further details). All records in the Specialised Register coded as 'asthma' were searched using the following terms:

(spacer* OR "holding chamber" or holding-chamber* OR volumatic OR nebuhaler* OR aerochamber* OR fisonair OR 
extension* OR "spacing device*" OR inspirease OR babyhaler* or MDI or turbuhaler) AND (nebuli*)

The most recent search of the Register was carried out in February 2013.

\section{Searching other resources}

We searched the bibliographies of all included papers and reviews for further references. We contacted authors of included studies for identification of any unpublished or missed trials.

\section{Data collection and analysis}

\section{Selection of studies}

One review author (CJC) originally checked abstracts identified by the above search and obtained the full text of publications of possibly relevant studies, including translation when required. Trials identified for potential inclusion were independently assessed by one review author (CJC) and William Griffiths, a student at St George's University of Londonfor the present update.

\section{Data extraction and management}

CJC extracted data and JAC checked them. They contacted trial authors by letter asking for clarification of allocation concealment, devices used, location of the participants and outcomes where these were not clear in the original publication.

\section{Assessment of risk of bias in included studies}

Two people (CJC, and William Griffiths or EW) independently assessed risk of bias for each study using the criteria outlined in the Cochrane Handbook for Systematic Reviews of Interventions (Higgins 2011). We resolved any disagreements by discussion. We assessed the risk of bias according to the following domains.

1. Random sequence generation.

2. Allocation concealment.

3. Blinding of participants and personnel.

4. Blinding of outcome assessment.

5. Incomplete outcome data.

6. Selective outcome reporting.

7. Other bias.

We graded each potential source of bias as high, low or unclear, and provided a quote from the study report together with a justification for our judgement in the 'Risk of bias' tables. We summarised the risk of bias judgements across different studies for each of the domains listed. We considered blinding separately for different key outcomes where necessary (e.g. for unblinded outcome assessment, risk of bias for all-cause mortality may be very different than for a participant-reported pain scale).

\section{Assessment of heterogeneity}

Heterogeneity was originally measured using the $\mathrm{Chi}^{2}$ test and latterly the $\mathrm{I}^{2}$ statistics for more recent updates. Where heterogeneity was found, we explored sources of heterogeneity and pooled results using a random-effects model, or did not pool across subgroups.

\section{Data synthesis}

We calculated a weighted treatment effect across trials using the Cochrane statistical package, Review Manager (RevMan; initially version 4, now 5.2). Results are expressed as risk ratios (RR) and a $95 \%$ confidence interval $(\mathrm{Cl})$ for dichotomous outcomes and mean differences (MD) and a 95\% $\mathrm{Cl}$ for continuous outcomes. We used a fixed-effect model for continuous outcomes, but also checked results using a random-effects model.

We have now separated the results for adults and children in each outcome, in view of the significant heterogeneity identified in the pooled analyses. Furthermore it can be argued that adults and children may differ in their ability to use the devices, their degree of airways reversibility and in their sensitivity to side effects from inhaled beta ${ }_{2}$-agonists.

We have not pooled the single-treatment trials because of concerns over confounding due to uncertainty about the relative dose delivered and the wide range of dose-ratios used (from 1:1 to 1:13, with the larger doses administered via nebuliser).

\section{Sensitivity analysis}

We performed sensitivity analyses on the basis of methodological quality. The results were originally re-analysed using only studies of the lowest risk of bias. Sensitivity analyses were performed to check on the effect of estimating standard deviations and the data reanalysed without any estimated results. In addition, we generated a funnel plot of hospital admissions to check for publication bias. In view of the temporary discontinuation of Volumatic spacers in some countries, we also separated the trials that used Volumatic from other types of spacer in an additional post hoc subgroup analysis.

\section{RES U L T S}

\section{Description of studies}

\section{Results of the search}

There were 35 included studies previously identified by literature searches conducted up to 2008. For this review update, our literature search covered the period 2008 to 2013 (see Figure 1 for details). We have included four new trials (Dhuper 2008; Direkwatanachai 2008; Ferrés 1989; Yasmin 2012), and have excluded three (Fayaz 2009; Hart 2009; Kaashmiri 2010). 


\section{Figure 1. Study flow diagram}

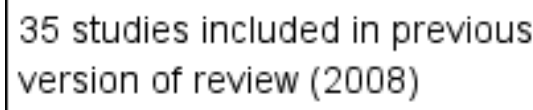

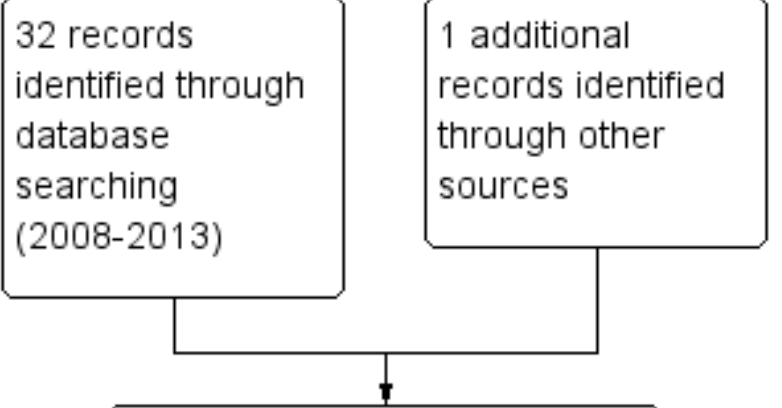

33 records after duplicates removed
19 records

excluded
3 studies

excluded, with reasons

1 additional reference to previously excluded study

2 additional references to previously included study 


\section{Included studies}

See Characteristics of included studies tables for full details.

There are now 1203 children (in 15 trials) and 613 adults (in 10 trials) who were randomised to spacer or nebuliser using multipletreatment protocols. There are also 487 children (in six trials) and 88 adults (in two trials) who were randomised to a single-treatment regimen. In addition there are six trials incorporating 207 children and 28 adults studied after hospital admission. Table 1 gives details of the location and design of each study, as well as the type of spacer used.

The studies come from all over the world. Only two were carried out in the community (Chong-Neto 2005; Morrone 1990); six trials have been conducted in an inpatient setting (Ba 1989; Burrows 2004; Coker 1995; Dewar 1999; Morley 1988; Parkin 1995), and all others were conducted in hospital emergency departments (although Direkwatanachai 2008 also recruited children from outpatients, and Yasmin 2012 only reports that the trial was carried out in the Department of Paediatrics). The single pre-hospital study comparing nebulisation to metered-dose inhaler (MDI) (Campbell 1995) was excluded, as there was no randomisation. Different beta ${ }_{2}$-agonists, spacers and nebulisers were represented in the studies.

The dosage ratio between delivery methods varied from 1:1 to 1:13, with the larger doses administered via nebuliser. The median dose administered via nebuliser was four times that administered via spacer, a dosage ratio of 1:4 (interquartile range (IQR) 1:2 to 1:8).

Many recent studies used multiple treatments at 10- to 30-minute intervals (Batra 1997; Chong-Neto 2005; Chou 1995; Colacone 1993; Direkwatanachai 2008; Duarte 2002; Idris 1993; Jamalvi 2006; Leversha 2000; Ploin 2000; Rao 2002; Rodrigo 1993; Rodrigo 1998;
Sannier 2007; Valencia 1999; Vivek 2003; Yasmin 2012). Most studies used commercially-available spacers (Aerochamber, Babyhaler, InspirEase, Lite Aire, Nebuhaler and Volumatic), but two studies from Brazil and one from Bangladesh (Chong-Neto 2005; Duarte 2002; Yasmin 2012) used home-made spacers in the form of a 500 $\mathrm{mL}$ mineral water plastic bottle. Duarte 2002 coated the bottle with detergent to avoid electrostatic charge, whilst Chong-Neto 2005 included 10 children treated with aerochamber and 10 children using a $500 \mathrm{~mL}$ water bottle glued onto the MDI with Araldite. The studies using salbutamol all used the racemic form of the drug.

\section{Excluded studies}

See Characteristics of excluded studies tables for full details.

\section{Risk of bias in included studies}

Overall, the methodological quality of the included studies was variable, with sequence generation and allocation concealment not described in many studies (see Characteristics of included studies). Many studies did not comment on withdrawals and dropouts, and also did not report whether intention-to-treat analysis was employed, but in short-term trials of acute treatment we would not expect large numbers of dropouts. The hospital admission rate reported in one study has been amended using an intention-totreat analysis (Colacone 1993).

In general the sample size of many individual studies was small, (range 18 to 196 participants in the emergency-room studies, and 28 to 61 for inpatients). Whilst eight of the 13 studies in adults used a double-blind, double-dummy design (Colacone 1993; Dhuper 2008; Idris 1993; Rodrigo 1993; Rodrigo 1998; Rao 2002; Salzman 1989; Turner 1988) only six of the 26 studies in children were double-blind (Ba 1989; Chong-Neto 2005; Kerem 1993; Leversha 2000; Ploin 2000; Robertson 1998); see Figure 2. 
Figure 2. Methodological quality summary: review authors' judgements about each methodological quality item for each included study.

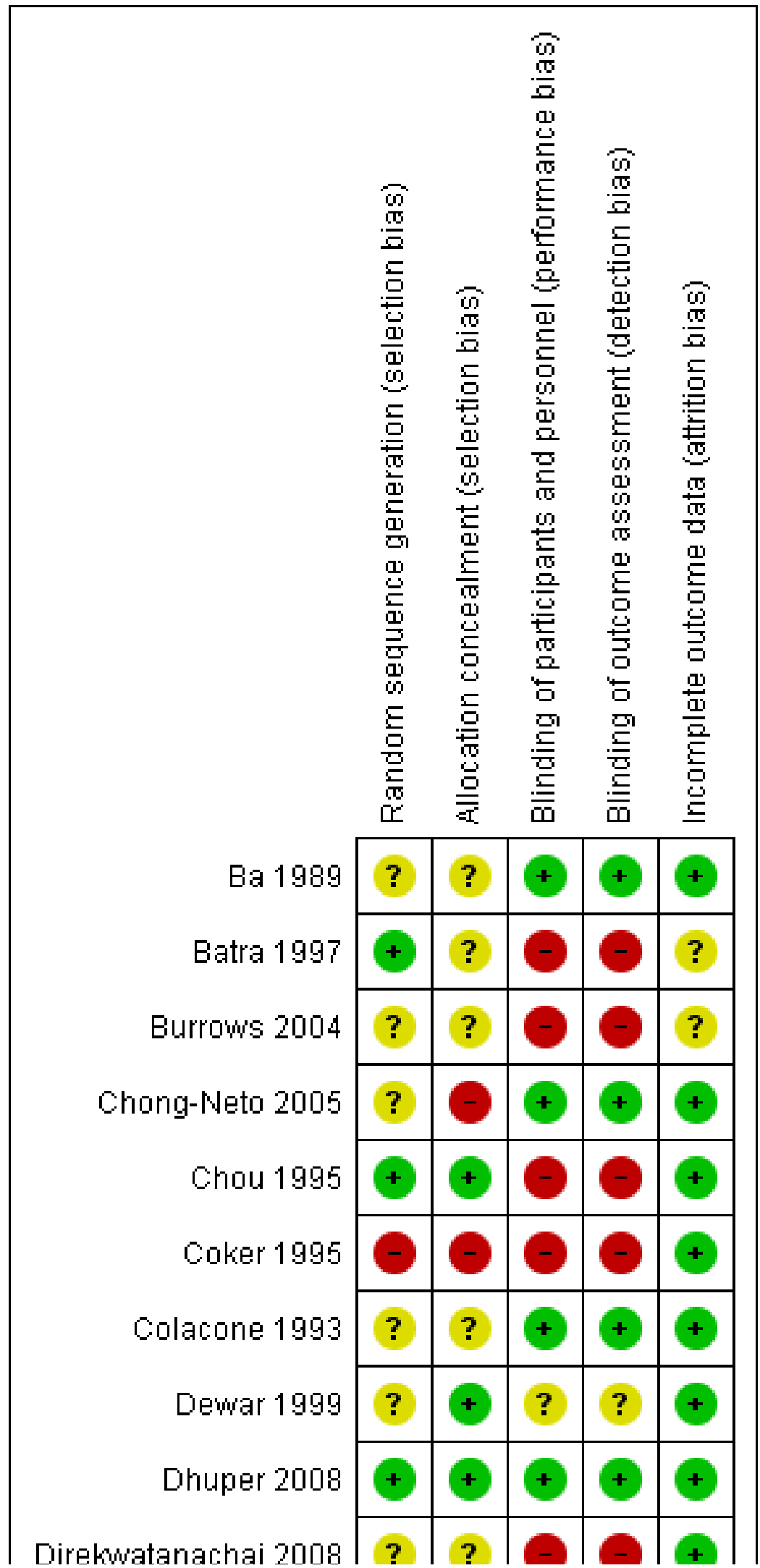


Figure 2. (Continued)

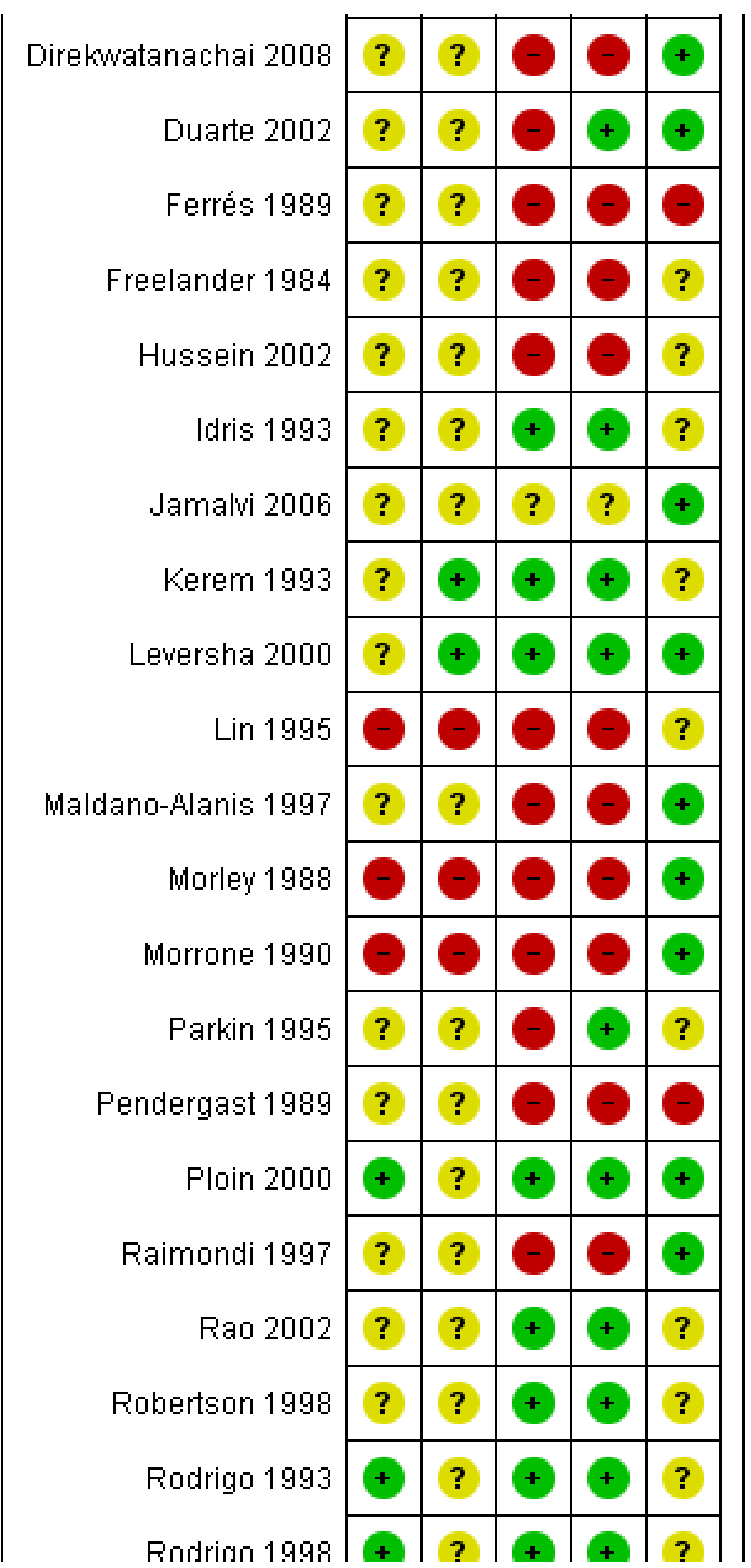


Figure 2. (Continued)

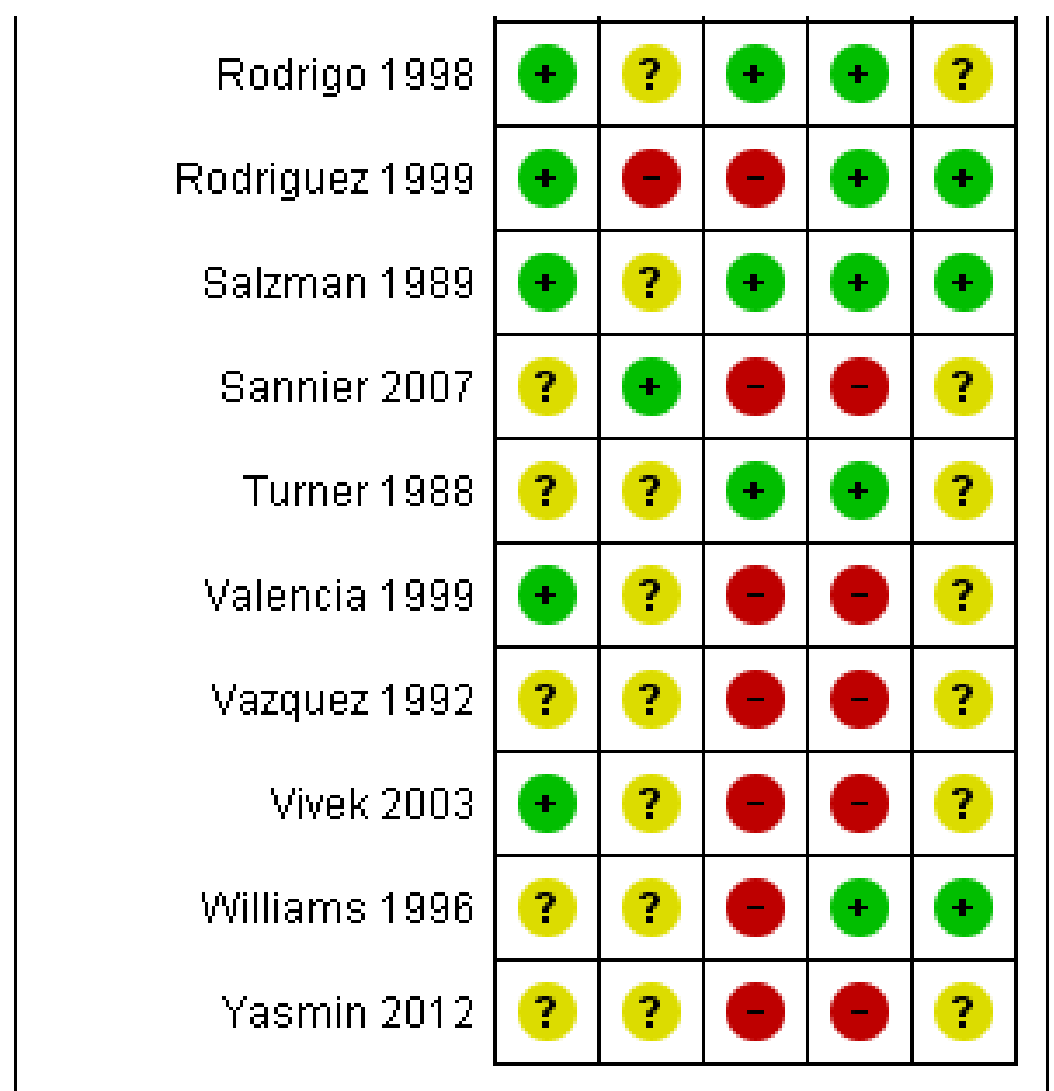

A funnel plot of hospital admissions did not suggest publication smaller studies showed equal spread of results on both sides of the bias in relation to the primary outcome of this review, since the overall risk ratio (Figure 3). 
Figure 3. Funnel plot of comparison: 1 Spacer (chamber) versus Nebuliser (Multiple treatment studies), outcome: 1.1 Hospital admission.

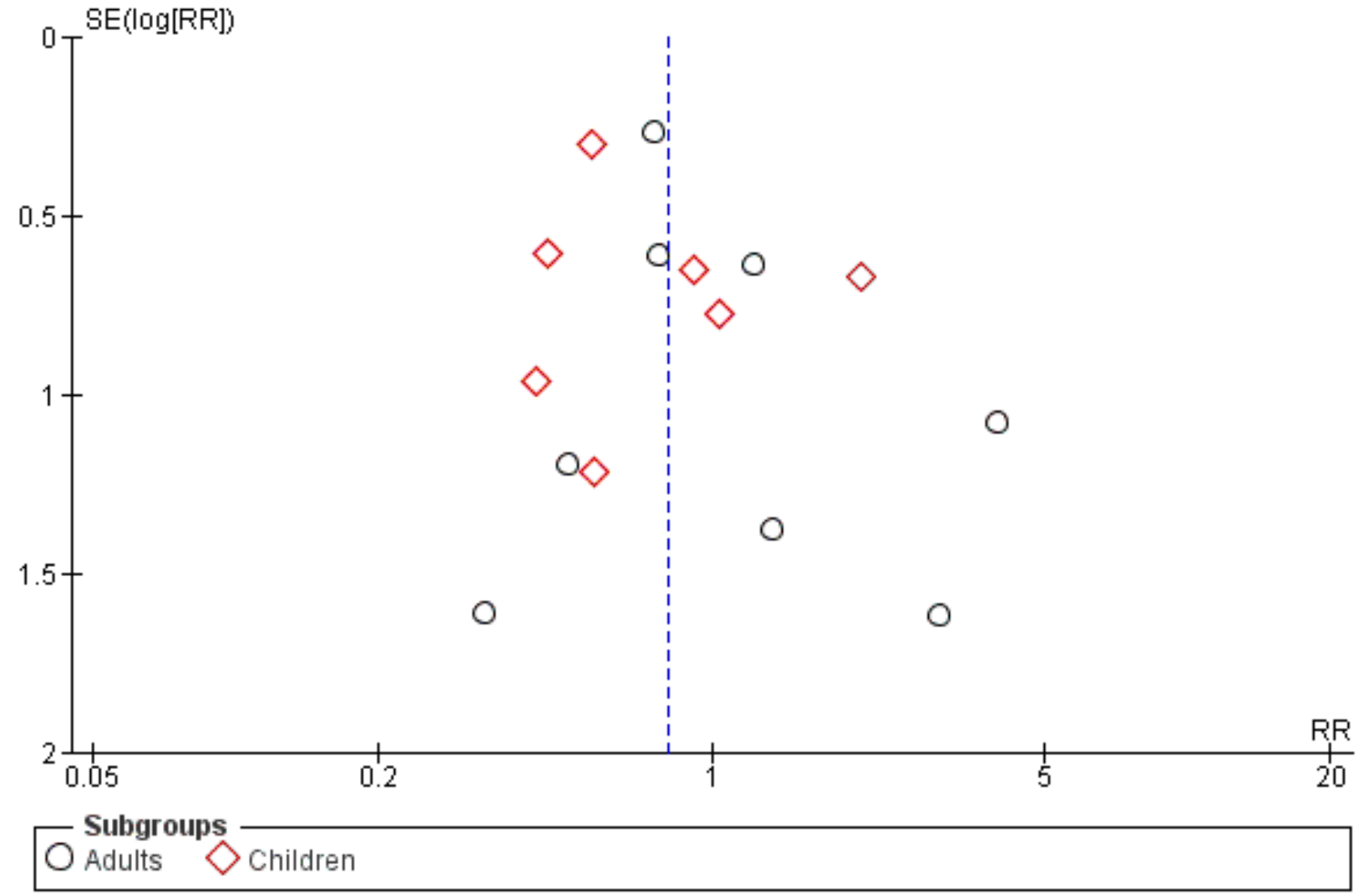

\section{'Summary of findings' Tables}

The assessments of risks of bias have been incorporated in two 'Summary of findings' tables, which are presented separately for children (Summary of findings for the main comparison) and adults (Summary of findings 2) for the 2013 update of this review.

\section{Effects of interventions}

See: Summary of findings for the main comparison Multiple treatment of beta $_{2}$-agonist via spacer (chamber) compared to nebuliser for children with acute asthma; Summary of findings 2
Multiple treatment of beta $_{2}$-agonist via spacer (chamber) compared to nebuliser for adults with acute asthma

\section{Spacer versus nebuliser multiple treatments}

Primary outcome: Hospital admission

Hospital admission rates did not differ significantly on the basis of delivery method in adults (risk ratio (RR) $0.94 ; 95 \%$ confidence interval (Cl) 0.61 to $1.43,9$ trials, $n=582$; Analysis 1.1) or in children (RR $0.71 ; 95 \% \mathrm{Cl} 0.47$ to $1.08,9$ trials, $\mathrm{n}=757$; Figure 4 ). No significant heterogeneity was observed. 
Figure 4. Forest plot of comparison: 1 Spacer (chamber) versus Nebuliser (Multiple treatment studies), outcome: 1.1 Hospital admission.

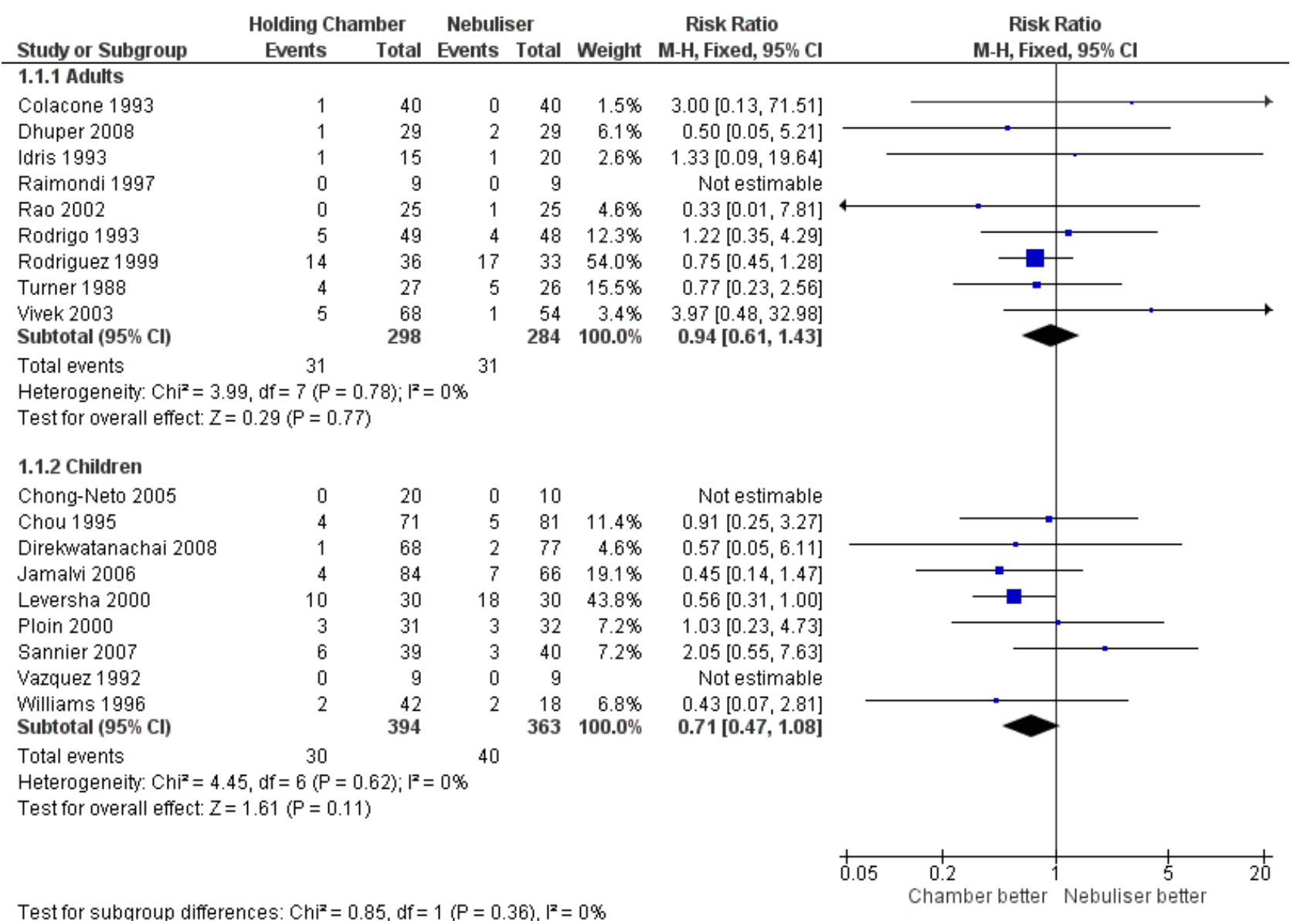

\section{Subgroup analysis by type of spacer}

In the light of the decision to temporarily withdraw Volumatic spacers from the UK market in 2005, we carried out a post hoc sensitivity analysis according to whether Volumatic spacers were used in each study. The type of spacer used is documented in Table 1 and this shows that the majority of adults and children studied used other types of spacer. No significant differences were found between the results from trials using Volumatic (166 adults and 163 children) and those using other types of spacer (366 adults and 515 children). There were no significant differences between the results for Volumatic and other spacer types in either adults or children (see Analysis 4.1). No studies included a direct comparison between Volumatic and other types of spacer.

\section{Secondary outcome: Treatment failure}

Three studies in children did not report admissions but did report data on poor outcomes (Batra 1997; Leversha 2000; Yasmin

2012). When these are pooled together with the data on hospital admissions, the risk ratio in children of admission or poor outcome is not significantly different between spacer and nebuliser (RR 1.00; $95 \% \mathrm{Cl} 0.75$ to $1.33,12$ trials, $\mathrm{n}=937$; Analysis 1.2 ). The definition of treatment failure varied across studies, and we included these data post hoc.

\section{Secondary outcome: Time spent in emergency department}

Time spent in the emergency department (ED) showed significant heterogeneity when the results from adults and children were pooled in the original version of this review, $\left(\mathrm{Chi}^{2}=8.2, \mathrm{df}=2, \mathrm{P}\right.$ $<0.02$ ). However, no significant heterogeneity was demonstrated when adults and children were analysed separately at that time. The results for adults and children have therefore been shown in separate subgroups in the analyses in Figure 5. 
Figure 5. Forest plot of comparison: 1 Spacer (chamber) versus Nebuliser (Multiple treatment studies), outcome: 1.3 Duration in emergency department (minutes). [mins].

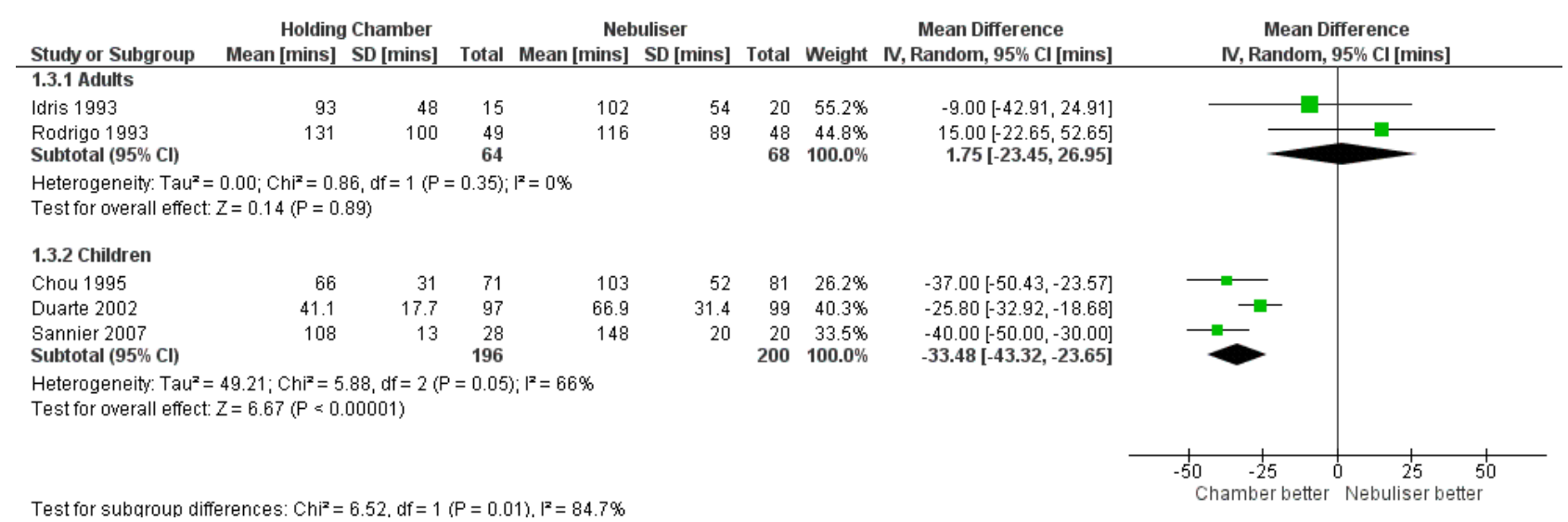

Duration in the ED in children was significantly shorter with the spacer (mean difference (MD) -33 minutes; $95 \% \mathrm{Cl}-43$ to -24 minutes, $I^{2}=66 \%, 3$ studies, $n=398$; Analysis 1.3$)$. This finding is based on three studies (Chou 1995; Duarte 2002; Sannier 2007), containing 396 participants, in which the median duration in ED on nebulised treatment was 103 minutes. The studies in children were open-label and did not use a double-dummy design, whereas the studies in adults were double-dummy so adults would have received both nebuliser and spacer. This is likely to have had a bearing on these results as nebulisation is much more timeconsuming than use of MDI and spacer (Duarte 2002). In adults the duration of the ED visit was similar in both groups (MD 2 minutes; $95 \% \mathrm{Cl}-23$ to 27 minutes; Analysis 1.2). Results in children and adults are shown using a random-effects model.

\section{Secondary outcome: Lung function}

No significant differences were demonstrated between the two delivery methods in terms of peak flow and forced expiratory volume $\left(\mathrm{FEV}_{1}\right)$ at 30 minutes and at the end of the study in either adults or children. More specifically, in the four studies in adults that included analysis of changes in lung function in the most severely affected participants (e.g. FEV $_{1}<30 \%$ predicted), there was no statistically significant difference between the two delivery methods (MD $-1.6 \%$ predicted; $95 \% \mathrm{Cl}-7.69$ to $4.49 \%$ ). The only study (Maldano-Alanis 1997) which found a significant difference in $\mathrm{FEV}_{1}$ between the nebuliser and spacer groups used a low dose of salbutamol via the spacer $(200 \mathrm{mcg}$ ), and showed a significant decline in $\mathrm{FEV}_{1}$ in this group three to six hours after the treatment was administered. This trial could not be included in the analysis as no standard deviations were reported and the authors did not respond to requests for further information. Maldano-Alanis 1997 did not contribute to the primary outcome of hospital admission.

\section{Secondary outcome: Pulse rate}

Pulse rate after treatment (expressed as \% change from baseline), was significantly lower when a spacer was used in children (MD $-5.41 \% ; 95 \% \mathrm{Cl}-8.34$ to $-2.48, \mathrm{I}^{2}=53 \%$, random-effects). In adults, no significant difference was found between methods (MD - $1.23 \%$; $95 \% \mathrm{Cl}-4.06$ to 1.60 , random-effects). These results were similar for fixed- and random-effects models. There was a significant difference between the pulse changes in adults and children (test for subgroup differences: $\mathrm{Chi}^{2}=4.03, \mathrm{df}=1(\mathrm{P}=0.04), \mathrm{I}^{2}=75.2 \%$, random-effects, see Figure 6). 
Figure 6. Forest plot of comparison: 1 Spacer (chamber) versus Nebuliser (Multiple treatment studies), outcome: 1.9 Rise in pulse rate (\% baseline) [\%].

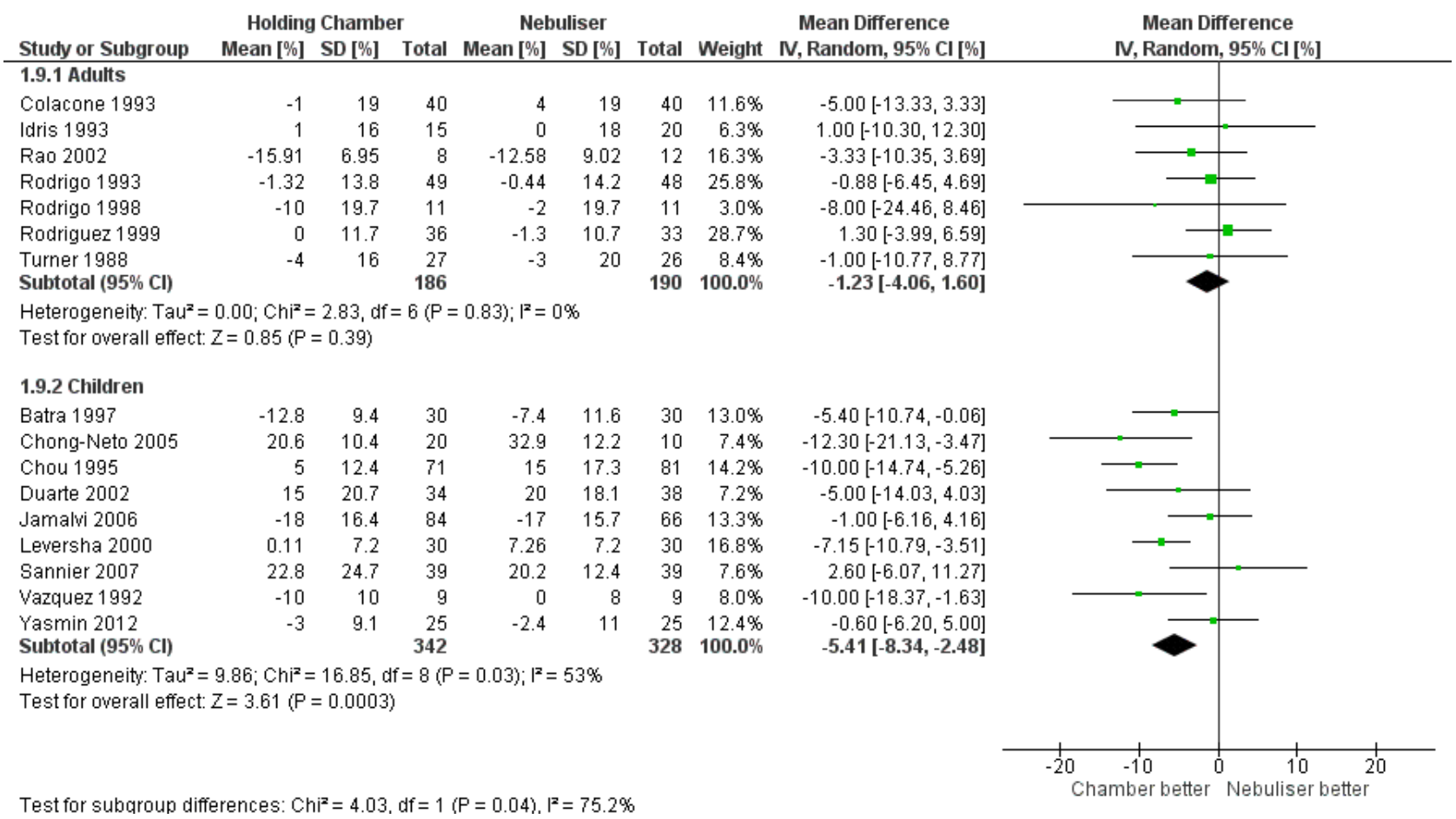

\section{Secondary outcome: Oxygen saturation}

There were no data available in adults for the outcome oxygen saturation. Oxygen saturation in children was not significantly different between groups at the end of the studies (MD - $0.19 \%$; $95 \% \mathrm{Cl}-0.61 \%$ to $0.24 \%, 6$ studies, 476 children; Analysis 1.10$)$. One study (Duarte 2002), however, reported that $25 \%$ of children treated with oxygen-driven nebuliser suffered desaturation at some point during treatment compared to $9 \%$ of those treated with MDI and spacer $(P=0.006)$.

\section{Secondary outcome: Adverse events (tremor)}

Development of tremor was more common with nebuliser treatment in the four studies that reported this in children (RR 0.64 $95 \% \mathrm{Cl} 0.44$ to 0.95 , random-effects), but the test for interaction between adults and children was not significant.

\section{Other secondary outcomes}

No significant differences were demonstrated between the two delivery methods for the other measured outcomes: change in respiratory rate and the number of participants given steroids.

We have made no attempt to combine the findings for symptom score as the scales used were highly variable and the standard deviation of results were rarely reported.

\section{Spacer versus nebuliser single treatments}

We did not pool results from single-treatment studies because of concern over confounding by the variable amounts of beta ${ }_{2}$ agonists delivered to the airways from the different delivery methods.
Blood gas results were reported in two studies (Kerem 1993; Lin 1995). The participant numbers were small but both show less deterioration in gases with a spacer. One study (Lin 1995) also measured lung function 15 minutes after the start of treatment and found a significantly greater rise in peak expiratory flow (PEF) at this time with the spacer (MD 10.1\% predicted; $95 \% \mathrm{Cl} 15.7$ to $4.4 \%$ ); this study is of low methodological quality, so this information should be interpreted with caution. More recently, Hussein 2002 reported similar changes in oxygen saturation in a single-treatment study in 60 children. The author has not responded to a request for further details.

\section{Spacer versus nebuliser Inpatient studies}

Individual patient data have been provided by the authors of Burrows 2004 on children who were aged two years or more and these have been incorporated into the 2013 update.

\section{Primary outcome: Duration of hospital admission}

The primary outcome of duration of admission was available from four studies (Burrows 2004; Dewar 1999; Morley 1988; Parkin 1995) but the results in Dewar 1999 were skewed and presented as medians so are not suitable for combination with the other two studies in children. The duration of admission did not show a significant difference between delivery methods in a single study in adults (MD -0.60 days; $95 \% \mathrm{Cl}-3.23$ to 2.03 ) or in the two studies in children (MD 0.33 days; $95 \% \mathrm{Cl}-0.10$ to 0.76 ), see Analysis 3.1.

Secondary outcomes: Respiratory rate, heart rate and oxygen saturation 
It was possible to combine the data provided by Burrows 2004 with the results from Dewar 1999 for three of the secondary outcomes (including 76 children).

There were no significant differences found in these children between spacers and nebulisers in respiratory rate (MD - $0.91 ; 95 \%$ $\mathrm{Cl}-3.20$ to 1.38 , Analysis 3.9), heart rate (MD 1.06; $95 \% \mathrm{Cl}-5.48$ to 7.61, Analysis 3.10) or oxygen saturation at discharge (MD 0.12; $95 \%$ $\mathrm{Cl}-0.42$ to 0.66 , Analysis 3.11 ).

The results from the individual studies have been outlined below.

Ba 1989 was a single-dose comparison in children, and did not measure the primary outcome (time to discharge). The design was double-blind with double dummy. Continuous intravenous aminophylline was given to all children in both groups. There was a significant difference between groups in baseline lung function, spacer baseline FEV 138.2 (SD 7.9)\% predicted and nebuliser 49.8 (SD 14)\% predicted. Results are only presented as change from baseline, and this will favour the spacer group. There was no significant difference in $\mathrm{FEV}_{1}$ between groups over three hours, and the significant advantage for the spacer in change in forced vital capacity (FVC) is probably due to baseline difference. The paper reported significantly more children treated with spacer increased their pulse rate at 10 minutes compared to the nebuliser group, but this data could not be used as the number of participants with increased pulse reported in the spacer group (17) was greater than the group total (14).

Coker 1995 was a single-dose comparison in children, and did not measure the primary outcome (time to discharge). There was no blinding and participants were allocated by alternation. No co-interventions were reported and no significant differences in respiratory score or PEF were found between groups over six hours.

Dewar 1999 compared multiple treatments in children, given up to one-hourly by each delivery method. Allocation was concealed with sequential pre-sealed envelopes and all children received oral steroids on admission and repeated on subsequent mornings for three to five days according to their recovery. No blinding was reported. Data for duration of stay were noted to be skewed by small numbers of lengthy inpatient stays so medians were used which did not show a significant difference between groups, (36.5 hours for the spacer group and 40 hours for the nebuliser group). Although readmission rates were lower in the spacer group, this group were also given a written asthma plan and this may have confounded the results for readmission and symptoms after discharge. Children requiring immediate intravenous treatment were excluded from the study, and five children were withdrawn due to deterioration requiring intravenous treatment (three in the spacer group and two in the nebuliser group). The authors calculated a significant cost benefit for the spacer group in terms of drug costs, GBP 5.43 per participant in the spacer group and GBP 20.25 in the nebuliser group $(P<0.001)$.

Morley 1988 was the only inpatient study in adults, and used multiple treatments. Allocation was by alternation and no blinding was described. Intravenous aminophylline and methylprednisolone were given at standard doses. Mean duration of hospitalisation was not significantly different between groups, 5.8 days in the spacer group and 6.4 days in the nebuliser group, mean difference of -0.6 days $(95 \% \mathrm{Cl}-3.2$ to 2.0$)$. No significant differences were found in lung function between groups.
Parkin 1995 compared multiple treatments in younger children (aged one to five years), but gave both salbutamol and ipratropium by spacer or nebuliser. The research nurse only was blinded and all children received intravenous or oral steroids. There was no significant difference in hours to discharge (spacer 53 hours and nebuliser 46 hours), hours to the change of treatments to four-hourly intervals or total number of inhaled doses received. Nine participants in the spacer group crossed over to nebuliser treatment, but their results were analysed by original group assignment (intention-to-treat analysis).

Burrows 2004 studied 29 children aged one to six years old with moderate to severe asthma according to British Thoracic Society (BTS) guidelines, who were hospitalised between September 2003 and February 2004. No significant differences were reported in any outcomes except for cost (which was GBP 7.68 per participant in the nebuliser group and GBP 5.96 per participant in the spacer group). The length of stay was 16.5 hours in the nebuliser group and 26.5 hours in the MDI and spacer group, with change in respiratory rate of -5.4 and -6.3 , change in pulse of 2.9 and 4.6, and change in oxygen saturation of 0.53 and 1.07 for nebuliser and spacer, respectively. The authors of Burrows 2004 have provided individual patient data for the children aged 2 years or more from this study and this has been added to duration of hospital admission from Parkin 1995. There was no significant difference in duration of admission (MD 0.33 days; $95 \% \mathrm{Cl}-0.10$ to 0.76 ) and shown in Analysis 3.1. Similarly the individual patient data from this study have been combined with results from Dewar 1999 as outlined in the secondary outcomes above.

\section{DISCUSSION}

\section{Summary of main results}

Overall, we found no significant advantage of wet nebuliser over metered-dose inhaler (MDI) with spacer administration of beta ${ }_{2}$ agonists in the treatment of acute asthma when treatments are repeated and titrated to the response of the participant for our primary outcome of hospital admissions. Thus the major take-home message from this review is that nebulisers have not been shown to be superior to spacers in preventing hospital admissions. Importantly we found that children had shorter emergency department (ED) visits when short-acting beta ${ }_{2}$ agonists were administered via spacer rather than nebuliser. The entire confidence interval indicated a patient-important benefit - we think parents would be happy to spend between 23 to 43 minutes less in the ED if their child was having an asthma attack, potentially saving health services time and money. It is not possible to say whether there is a time benefit in adults; this may be partly because all the adult trials contributing to this outcome were double-blind and double-dummy. Since both groups received both nebuliser and spacer this may have confounded any possible time saving from using the spacer. In addition hypoxia was reduced, and pulse rates and risk of tremor were lowered compared to participants receiving the same beta ${ }_{2}$-agonist via wet nebulisation.

In clinical practice the dose of beta ${ }_{2}$-agonist delivered to the airways varies depending on the type of nebuliser or spacer used and the characteristics of the individual's airways at that time (Lipworth 1997). Uncertainty over the dose of beta ${ }_{2}$-agonists required through any delivery method was overcome in many of the studies ( 613 adults and 1203 children) by repeating treatments at short intervals. For example, one respule (via nebuliser) or 
four to six puffs (via spacer) every 10 to 30 minutes until the person responded to treatment (see Table 1 for a list of trials using multiple treatments). This approach reduced confounding by different dosages of drug delivered.

\section{Overall completeness and applicability of evidence}

People with life-threatening asthma exacerbations were excluded from the studies (for example those who were considered for ventilation). We do not know how this patient group would respond to treatment using spacers, or indeed whether they would be able to use a spacer under these circumstances.

Only two small studies were carried out in a community setting (Chong-Neto 2005; Morrone 1990) and this review did not compare people being randomised to receive either nebuliser or spacer at home for delivery of beta $_{2}$-agonists when their symptoms get worse. While we do not have evidence in these populations, it is logical to conclude that provided people are proficient at using their spacer (or can clearly instruct their child to use their spacer correctly) there is no advantage in buying an expensive home nebuliser when a spacer is cheaper and more portable. However, our confidence in this statement is low as the evidence in this review comes form an ED setting where treatment can be supervised by health professionals.

Few authors reported specifically on numbers of people presenting who were excluded from each study, and intention-to-treat analysis was not usually reported. Thus it is not entirely clear how these results apply to all people who present with an exacerbation.

Analysis of the data regarding lung function tests in many papers was complicated by a lack of standardised reporting. In addition, data regarding standard deviation related to the changes that were measured were not always reported. Peak flow and forced expiratory volume $\left(\mathrm{FEV}_{1}\right)$ were the most commonly reported measurements and these were both included in the outcome tables. These concerns are not enough to overturn our confidence in the patient-important outcome of reduced time in the ED in children.

\section{Quality of the evidence}

Sequence generation and allocation concealment were unclear in many of the included studies, and only eight studies in adults and six studies in children used a double-bind (double-dummy) design (see Figure 2). Performance and assessment bias might therefore have reduced the size of true differences between the two delivery methods.

\section{Agreements and disagreements with other studies or reviews}

\section{Use of oral or parenteral steroids}

Successful response to beta ${ }_{2}$-agonists does not diminish the necessity to consider oral steroids in acute attacks of asthma. A previous meta-analysis demonstrated that steroids clearly reduce relapses when given to patients following discharge, and reduce hospitalisation when used early in the course of emergency treatment (Rowe 2007).

\section{Dosage of beta benist $_{2}$}

The studies included in this review used nominal dosage ratios between nebuliser and spacer that varied from 1:1 to 1:13 (lower dose in the spacer). One of the included studies plotted a log doseresponse curve (Colacone 1993); the equivalent dose ratio found in this study was 1:6 with the lower dose in the spacer. In adults, no additional benefit was found using six puffs of salbutamol (100 mcg each) given at 10-minute intervals through a Volumatic spacer, when compared with four puffs at 10-minute intervals (Rodrigo 1996). A comparison in children between doses of $0.5 \mathrm{mg} /$ $\mathrm{kg}$ and $1.5 \mathrm{mg} / \mathrm{kg}$ given at 20-minute intervals via nebuliser showed significantly greater improvement in lung function at the higher dose (Schuh 1989).

Experimental evidence suggests that the beta ${ }_{2}$-agonist should be released (actuated) into the spacer in individual puffs that can be inhaled by tidal breathing or single breaths (Gleeson 1988; Newman 1984). Some of the early studies mentioned difficulty with the valve movement with some spacers; however, this did not appear to be a problem in more recent studies. Some children may co-operate more with either spacer or nebuliser, so this may be an important factor in the choice of delivery method.

\section{Type of spacer}

Two studies compared different types of spacer; Chong-Neto 2005 studied 10 children with aerochamber and 10 with a home-made spacer constructed from a $500 \mathrm{~mL}$ mineral water bottle. The study failed to identify differences between the types of spacer other than lower pulse rates with the Aerochamber than with the homemade spacer. Williams 1996 included 20 children treated with an Aerochamber and 22 children treated with an ACE spacer (both around $150 \mathrm{~mL}$ ) and found no significant differences between the groups in respiratory rate and lung function.

Overall comparisons between types of spacer are confounded by all the other differences between the designs of each trial. In view of the discontinuation of Volumatic spacers in the UK in 2005, additional details to allow identification of type of spacer used have been added in Table 1. This indicates that the findings of this review for the primary outcome of hospital admission are unchanged in children when trials using Volumatic spacers are excluded, but the confidence intervals widen for adults as fewer data contribute to the outcome. We found no significant subgroup differences for any outcome between the trials using Volumatic or other spacers.

\section{Cost of treatment}

Cost considerations may dictate which delivery system is used in different settings. In many parts of the world nebulisation is not available in peripheral hospitals and clinics for economic reasons (Rao 2002). Several recent studies have now included a calculation of costs of drug treatment (Burrows 2004; Chong-Neto 2005; Dewar 1999; Dhuper 2008; Duarte 2002) and found a cost advantage for spacer delivery.

Total costs in a hospital setting are more complex to calculate; however, when patients return to the community the cost of a home nebuliser and respules is considerably more than an MDI and spacer (and the nebuliser requires regular maintenance). A before-after ED study (Newman 2002) assessed the consequences of changing the acute asthma treatment algorithm from nebulised to $\mathrm{MDI} /$ spacer albuterol (salbutamol). Admission rates did not rise following the 
change in delivery method and duration of stay in the ED fell significantly from 175 minutes to 164 minutes. There were also reductions in charges that did not reach significance. Lower relapse rates following the change to $\mathrm{MDI} / \mathrm{spacer}$ delivery were confounded by other changes, such as an asthma bag containing a spacer, peak-flow meter, instructional handout and canister of inhaled corticosteroid given to the patients at discharge. This makes data on relapse rates difficult to interpret, although significant reductions were seen following the combined interventions. As expected, the total dose of albuterol given to patients was lower with $\mathrm{MDI} /$ spacer delivery.

\section{Changing Practice}

Current guidelines recommend $\mathrm{MDI} /$ spacer delivery of beta ${ }_{2}$ agonists in acute asthma (BTS/SIGN 2011; GINA 2012). However, implementing research findings is not an easy process, and Powell 2001 found that successfully changing hospital practice from nebulisers to spacers required a structured strategy to overcome the 'nebuliser culture' both in hospital medical and nursing staff, as well as parents and families of children with asthma. Osmond 2007 carried out a survey of the use of nebulisers and spacers in Canadian paediatric EDs, and found that $21 \%$ of emergency physicians used MDI and spacer; the largest perceived barriers amongst non-users included safety and costs, and the lack of a physician champion for change.

\section{AUTHORS' CONCLUSIONS}

\section{Implications for practice}

1. For adults seen and assessed for acute asthma, this review found no significant differences between the two delivery methods. Consequently, the choice of delivery method should reflect patient preference, practice situations and formal economic evaluation

2. In children, no outcomes were significantly worse with the spacers, and the available evidence suggests that in most cases nebulisers could be replaced with spacers to deliver beta $_{2}-$ agonists in acute asthma. Moreover, other observed benefits (time spent in emergency department, oxygenation and side effects) may favour the groups treated with metered-dose inhaler (MDI) and spacer.

3. The experimental method adopted in many of the studies was to give repeated treatments at short intervals (e.g. one respule via a nebuliser or four puffs of a MDI via a spacer every 10 to 15 minutes). The number of treatments required was adjusted to the individual patient's response, overcoming the uncertainty of dosage delivery from different devices. Tidal breathing is easier for adults and children using a spacer for acute asthma, but each puff should be inhaled from the spacer before the next puff is delivered into the spacer. Current evidence is therefore based upon titrated treatment regimens and this should be considered when implementing any change in practice.

4. The studies excluded people with life-threatening asthma; therefore, the results of this meta-analysis should not be extrapolated to this patient population.

\section{Implications for research}

1. Further studies are required to confirm whether these findings, largely from hospital emergency departments, can be replicated in the community setting.

2. Further studies in children and adults with more severe asthma are required to confirm whether spacers are as efficacious as nebulisers in this group.

3. In order to avoid confounding due to differences in the dose of drug delivered to the airways, future studies should use multiple treatments at short intervals titrated against individual patient response.

4. Implementation of change to continue to overcome the 'nebuliser culture' needs further work.

\section{ACKNOWLEDGEMENTS}

Partial funding from the NHS Executive, North Thames and Eastern Regions supported this review. The reviewers would like to acknowledge Jacqueline Crilly (JAC), co-author of the 2003, 2006 and 2008 updates of this review. In addition, the reviewers would like to acknowledge the assistance provided by the Cochrane Airways Review Group staff (Steve Milan, Anna Bara, Jane Dennis, Toby Lasserson, Liz Stovold) in identifying the trials from the register, obtaining copies of the papers, and translating a paper from Spanish. We would like to acknowledge Robert Chapman for his assistance with the methodological assessment of the trials in the original version of this review, Janet Reynolds from the Watford Postgraduate Medical Centre Library for help with obtaining reprints and $\mathrm{Mr}$ and Mrs Clement for their assistance in translation of papers from Spanish and Portuguese. We also thank Kirsty Olsen for copy editing an update of this review and William Griffiths (St George's, University of London) for help with 'Risk of bias' assessments and data extraction for the 2013 update.

We would like to thank the following authors for responding to correspondence and supplying additional data for the review: Tom Burrows, Professor Gerard Canny, Dr Chong Neto, Dr Katherine Chou, Dr Mahmut Coker, Dr. Jeroni Ferrés, Dr Yung-Zen Lin, Dr Nelson Morrone, Dr Dominique Ploin, Dr C Robertson, Dr Ivan Solarte, Dr Gary Salzman, Joan Turner, Dr P Vivek. 


\section{R E F E R E N C E S}

\section{References to studies included in this review}

Ba 1989 \{published data only\}

Ba M, Spier S, Lapierre G, Lamarre A. Wet nebulizer versus spacer and metered dose inhaler via tidal breathing. Journal of Asthma 1989;26:355-8. [MEDLINE: 192630]

\section{Batra 1997 \{published data only\}}

Batra V, Sethi G, Sachdev H. Comparative efficacy of jet nebuliser and metered dose inhaler with spacer device in the treatment of acute asthma. Indian Pediatrics 1997;34:497-503.

\section{Burrows 2004 \{published and unpublished data\}}

Burrows T, Connett GJ. The relative benefits and acceptability of metered dose inhalers and nebulisers to treat acute asthma in preschool children [Abstract]. Thorax 2004;59(Suppl II):ii20. [CN-00517341]

\section{Chong-Neto 2005 \{published data only\}}

Alves Cardozo C. Cost of treatment of acute asthma in children using different inhaler devices [Dissertation]. Pontifícia Universidade Católica do Paraná (Brazil) 2005:88p.

* Chong-Neto HJ, Chong-Silva DC, Marani DM, Kuroda F, Olandowisky M, Noronha L, et al. Different inhaled devices in acute asthma attacks: a randomized, double-blinded, placebo controlled study. Jornal de Pediatria 2005;81:298-304.

\section{Chou 1995 \{published and unpublished data\}}

Chou KJ, Cunningham SJ, Crain EF. Metered-dose inhalers with spacers versus nebulizers for pediatric asthma. Archives of Pediatrics and Adolescent Medicine 1995;149:201-5.

\section{Coker 1995 \{published data only\}}

Coker M, Tanac R. Comparison of three methods of inhaling salbutamol in acute childhood asthma. Turkish Journal of Medical Sciences 1995;23:293-7.

\section{Colacone 1993 \{published data only\}}

Colacone A, Afilalo M, Wolkove N, Kreisman H. A comparison of albuterol administered by metered dose inhaler (and holding chamber) or wet nebulizer in acute asthma. Chest 1993;104:835-41.

\section{Dewar 1999 \{published data only\}}

Dewar AL, Stewar A, Cogswell JJ, Connett GL. A randomised controlled trial to assess the relative benefits of large volume spacers and nebulisers to treat acute asthma in hospital. Archives of Disease in Childhood 1999;80:421-3.

\section{Dhuper 2008 \{published data only\}}

Dhuper S, Chandra A, Ahmed A, Bista S, Moghekar A, Verma R, et al. Bronchodilator administration between MDI's with a disposable spacer and nebulizer used for acute asthma treatment: a comparison of efficacy and cost analysis [Abstract]. American Thoracic Society International Conference; 2008 May 16-21; Toronto. 2008.

* Dhuper S, Chandra A, Ahmed A, Bista S, Moghekar A, Verma R, et al. Efficacy and cost comparisons of bronchodilatator administration between metered dose inhalers with disposable spacers and nebulizers for acute asthma in an inner-city adult population. Journal of Emergency Medicine 2011; Vol. 40, issue 3:247-255

\section{Direkwatanachai 2008 \{published data only\}}

* Direkwatanachai C, Teeratakulpisarn J, Suntornlohanakul S, Trakultivakorn M, Ngamphaiboon J, Wongpitoon N, et al. Comparison of salbutamol efficacy in children--via the metereddose inhaler (MDI) with Volumatic spacer and via the dry powder inhaler, Easyhaler, with the nebulizer--in mild to moderate asthma exacerbation: a multicenter, randomized study. Asia-Pacific Journal of Allergy and Immunology 2011:29:25-33.

Sirikul C, Chumpakdee K, Vangveeravong M. A comparative study of efficacy of salbutamol via metered dose inhaler (MDI) with volumatic spacer and via dry powder inhaler (DPI) Easyhaler to nebulization in mild to moderate severity acute asthma exacerbation in children [Abstract]. Journal of Allergy and Clinical Immunology 2008;121(2 Suppl 1):S156.

Vangveeravong M. A comparative study of efficacy of salbutamol via metered dose inhaler with volumatic spacer and via dry powder inhaler, easyhaler, to nebulization in mild to moderate severity acute asthma exacerbation in childhood. Journal of the Medical Association of Thailand 2008;91(Suppl 3):S115-23.

Duarte 2002 \{published data only\}

Duarte M, Camargos P. Efficacy and safety of a home-made nonvalved spacer for bronchodilator therapy in acute asthma. Acta Paediatrica 2002;91:909-13.

\section{Ferrés 1989 \{published data only\}}

Ferrés J, Querol J, Guasch, E. Beta2-adrenergic stimulants: Nebulizer versus holding chambers for the treatment of pediatric acute asthma. Anales Españoles de Pediatría 1989;31(2):175.

\section{Freelander 1984 \{published data only\}}

Freelander M, Van Asperen PP. Nebuhaler versus nebuliser in children with acute asthma. BMJ 1984;288:1873-4.

\section{Hussein 2002 \{published data only\}}

Hussein ZM, Bader-Eldin OMK, Galal AA, Abd-Allah SA. Metered dose inhaler with spacer versus nebulizer in children with acute bronchial asthma. European Respiratory Society Annual Congress; 2002 Sep 14-18; Sweden. 2002.

\section{Idris 1993 \{published data only\}}

Idris AH, McDermott MF, Raucci JC, Morrabel A, McGorray S, Hendeles L. Emergency department treatment of severe asthma. Metered-dose inhaler plus holding chamber is equivalent in effectiveness to nebulizer. Chest 1993;103:665-72.

\section{Jamalvi 2006 \{published data only\}}

Jamalvi SW, Raza SJ, Naz F, Shamim S, Jamalvi SM. Management of acute asthma in children using metered dose inhaler and small volume nebulizer. Journal of the Pakistan Medical Association 2006; Vol. 56, issue 12:595-9. 
Kerem 1993 \{published and unpublished data\}

Kerem E, Levison H, Schuh S, OBrodovich H, Reisman J, Bentur L, et al. Efficacy of albuterol administered by nebulizer versus spacer device in children with acute asthma. Journal of Pediatrics 1993;123:313-7.

\section{Leversha 2000 \{published data only\}}

Leversha AM, Campanella SG, Aickin RP, Asher MI. Costs and effectiveness of spacer versus nebulizer in young children with moderate and severe asthma. Journal of Pediatrics 2000;136(4):497-502.

\section{Lin 1995 \{published and unpublished data\}}

Lin Y-Z, Hsieh K-H. Metered dose inhaler and nebuliser in acute asthma. Archives of Disease in Childhood 1995;72:214-8.

\section{Maldano-Alanis 1997 \{published data only\}}

Maldano-Alanis M, Linares-Zapien F, Rio-Navarro B, SiennaMonge J. Comparison between salbutamol administered through metered dose inhalers with spacers vs nebulisers in children with acute asthma. Boletin Medico del Hospital Infantil de Mexico 1997;54:374-8.

\section{Morley 1988 \{published data only\}}

Morley TF, Marozsan E, Zappasodi SJ, Gordon R, Griesback R, Giudice JC. Comparison of beta-adrenergic agents delivered by nebulizer vs metered dose inhaler with InspirEase in hospitalised asthmatic patients. Chest 1988;94(6):1205-10.

\section{Morrone 1990 \{published and unpublished data\}}

Morrone N, Freire JA, Pereira CA, Ferreira AK. Bronchodilation induced by fenoterol in asthmatic patients: comparison of jet nebulization and spacer device. Revista Paulista de Medicina 1990;108:83-7.

\section{Parkin 1995 \{published data only\}}

Parkin PC, Saunders NR, Diamond SA, Winders PM, Macarthur C Randomised trial spacer $v$ nebuliser for acute asthma. Archives of Disease in Childhood 1995;72:239-40.

\section{Pendergast 1989 \{published data only\}}

Pendergast J, Hopkins J, Timms B, Van Asperen PP. Comparative efficacy of terbutaline administered by Nebuhaler and by nebulizer in young children with acute asthma. Medical Journal of Australia 1989;151:406-8.

\section{Ploin 2000 \{published and unpublished data\}}

Ploin D, Chapuis FR, Stamm D, Robert J, David L, Chatelain PG, et al. High dose aerosolised salbutamol via chamber and nebuliser in wheezy infants and young children [Fortes doses de salbutamol par aérosol doseur et chambre d'inhalation chez les nourrissons et les jeunes enfants siffleurs]. Revue Francaise $D^{\prime}$ Allergologie Immunologie Clinique 2001;41:155-64.

* Ploin D, Chapuis FR, Stamm D, Robert J, David L, Chatelain PG, et al. High-dose Albuterol by metered-dose inhaler plus a spacer device versus nebulisation in pre-school children with recurrent wheezing: a double-blind, randomised equivalence trial. Pediatrics 2000;106(2):311-7.

\section{Raimondi 1997 \{published data only\}}

Raimondi AC, Schottlender J, Lombardi D, Molfino N. Treatment of acute severe asthma with inhaled albuterol delivered by jet nebulizer, metered dose inhaler with spacer or dry powder. Chest 1997;112(1):24-8

\section{Rao 2002 \{published data only\}}

Rao NA, Rizvi N. The efficacy of salbutamol delivered by inhaler plus spacer device and nebulizer in acute asthma: a comparative study. Journal-College of Physicians and Surgeons of Pakistan 2002;12(10):579-82.

\section{Robertson 1998 \{published data only\}}

Robertson C, Norden M, Fitzgerald D, Connor F, Van Asperen PP, Cooper PJ, et al. Treatment of acute asthma: salbutamol via jet nebuliser vs spacer and metered dose inhaler. Journal of Paediatrics and Child Health 1998;34:142-6.

\section{Rodrigo 1993 \{published data only\}}

Rodrigo G, Rodrigo C. Comparison of salbutamol delivered by nebulizer or metered-dose inhaler with a pear-shaped spacer in acute asthma. Current Therapeutic Research, Clinical and Experimental 1993;54:797-808.

\section{Rodrigo 1998 \{published data only\}}

Rodrigo C, Rodrigo G. Salbutamol treatment of acute severe asthma in the ED: MDI versus hand held nebulizer. American Journal of Emergency Medicine 1998;16:637-42.

Rodriguez 1999 \{unpublished data only\}

Rodriguez IS, Buitrago JR, Garcia RL. Nebulizer versus inhale plus holding chamber for acute asthma in adults. Data on file 1999.

Salzman 1989 \{published data only\}

Salzman GA, Steele MT, Pribble JP, Elenbaas RM, Pyszczynski DR. Aerosolized metaproterenol in the treatment of asthmatics with severe airflow obstruction. Comparison of two delivery methods. Chest 1989;95:1017-20.

\section{Sannier 2007 \{published data only\}}

Sannier N, Timsit S, Cojocaru B, Leis A, Wille C, Garel D, et al. Metered-dose inhaler with spacer versus nebulization for severe and potentially severe acute asthma treatment in the pediatric emergency department. [French]. Revue Francaise d Allergologie et d Immunologie Clinique 2007; Vol. 47, issue 2:64-71.

Turner 1988 \{published and unpublished data\}

Turner JR, Corkery KJ, Eckman D, Gelb AM, Lipavsky A, Sheppard D. Equivalence of continuous flow nebulizer and metered-dose inhaler with reservoir bag for treatment of acute airflow obstruction. Chest 1988;93:476-81.

\section{Valencia 1999 \{published data only\}}

Valencia ML, Manotas R. Inhaled versus nebulised salbutamol in the management of acute asthma exacerbation in pre-school children. A randomised comparative trial [Salbutamol inhalado o nebulizado en el tratamiento de la exacerbacion aguda del asma en el preescolar. Estudio comparativo aleatorizado]. latreia 1999;12(3):130-4. 


\section{Vazquez 1992 \{published data only\}}

Vazquez Cordero C, Corera Sanchez M, Molinuevo Alvaro J. Comparison of treatment of acute asthma attacks in children with salbutamol dispensed by the Volumatic dispenser or by a nebulizer. Anales Espanoles de Pediatria 1992;36:359-62.

Vivek 2003 \{published and unpublished data\}

Vivek $\mathrm{P}$, Joshi M. A randomised controlled trial comparing the efficacy of inhalation therapy by spacer device $v$ nebulizer in acute exacerbation of asthma. Thorax 2003;58(Suppl 3):iii44.

\section{Williams 1996 \{published data only\}}

Williams JR, Bothner JP, Swanton RD. Delivery of albuterol in a pediatric emergency department. Pediatric Emergency Care 1996;12(4):263-7.

\section{Yasmin 2012 \{published data only\}}

Yasmin S, Mollah AH, Basak R, Islam KT, Chowdhury YS. Efficacy of salbutamol by nebulizer versus metered dose. Mymensingh Medical Journal 2012; Vol. 21, issue 1:66-71.

\section{References to studies excluded from this review}

\section{Beasley 1985 \{published data only\}}

Beasley CRW, O'Donnell TV. Pear shaped spacer Nebuhaler compared with nebulised solution for terbutaline administration in acute severe asthma. New Zealand Medical Journal 1985;98:854-5. [MEDLINE: 191150]

\section{Benton 1989 \{published data only\}}

Benton G, Thomas RC, Nickerson BG, McQuitty JC, Okikawa J. Experience with a metered dose inhaler with spacer in pediatric emergency department. Annals of Disease in Childhood 1989;43:678-81.

\section{Berenberg 1985 \{published data only\}}

Berenberg MJ, Baigelmann W, Cupples LA, Pearce L. Comparison of metered-dose inhaler attached to an aerochamber with an updraft nebuliser for the administration of metaproterenol in hospitalised patients. Journal of Asthma 1985;22:87-92.

\section{Campbell 1995 \{published data only\}}

Campbell IA, Colman SB, Mao JH, Prescott RJ, Weston CFM. An open, prospective comparison of beta 2 agonists given via nebuliser, Nebuhaler, or pressurised inhaler by ambulance crew as emergency treatment. Thorax 1995;50:79-80. [MEDLINE: 19920]

\section{Deerojanawong 2005 \{published data only\}}

* Deerojanawong J, Manuyakorn W, Prapphal N, Harnruthakorn C, Sritippayawan S, Samransamruajkit R. Randomized controlled trial of salbutamol aerosol therapy via metered dose inhaler-spacer vs. jet nebulizer in young children with wheezing. Pediatric Pulmonology 2005;39(5):466-72.

Wiparat, M. A prospective randomized controlled trial of salbutamol aerosol therapy via metered dose inhaler-spacer versus jet nebulizer for young children with acute wheezing [Dissertation]. Chulalongkorn Univerisity. Bangkok. (Thailand). Graduate School. 2002.

\section{Fayaz 2009 \{published data only\}}

Fayaz M, Sultan A, Rai M E. Comparison between efficacy of mdi+spacer and nebuliser in the management of acute asthma in children. Journal of Ayub Medical College Abbottabad 2009;21(1):32-4.

\section{Fuglsang 1986 \{published data only\}}

Fuglsang G, Pedersen S. Comparison of Nebuhaler(R) and nebulizer treatment of acute severe asthma in children. European Respiratory Journal 1986;69:109-13. [MEDLINE: 191270]

\section{Hart 2009 \{published data only\}}

Hart M, Abmas E, Boehm R, Hernandez G, Millard M. Comparison of valved-holding chamber (VHC)-facemask/ mouthpiece with small volume nebulizer-facemask (SVN-F for bronchodilator delivery [Abstract]. European Respiratory Society Annual Congress; 2009 Sep 12-16; Vienna. 2009.

\section{Hodder 1988 \{published data only\}}

Hodder RV, Calcutt LE, Leech JA. Metered dose inhaler with spacer is superior to wet nebulisation for emergency room treatment of acute severe asthma. Chest 1988;94 Suppl:53.

\section{Jasper 1987 \{published data only\}}

Jasper AC, Mohsenifar Z, Kafan S, Goldberg H, Koerner SK. Costbenefit comparison of aerosol bronchodilator delivery methods in hospitalised patients. Chest 1987;91:614-8.

\section{Kaashmiri 2010 \{published data only\}}

Kaashmiri M, Shepard J, Goodman B, Lincourt WR, Trivedi R, Ellsworth A, et al. Repeat dosing of albuterol via metereddose inhaler in infants with acute obstructive airway disease: A randomized controlled safety trial. Paediatric Emergency Care 2010;26(3):197-202.

\section{Levitt 1995 \{published data only\}}

Levitt MA, Gambrioli EF, Fink JB. Comparative trial of continuous nebulization versus metered-dose inhaler in the treatment of acute bronchospasm. Annals of Emergency Medicine 1995;26:273-7.

\section{Madsen 1982 \{published data only\}}

Madsen EB, Bundgaard A, Hidinger K. Cummulative doseresponse study comparing terbutaline pressurised aerosol administered via a pear-shaped spacer and terbutaline in a nebulized solution. European Journal of Clinical Pharmacology 1982;23:27-30.

\section{Maguire 1991 \{published data only\}}

Maguire GP, Newman T, DeLorenzo LJ, Brown RB, Stone D. Comparison of a hand-held nebulizer with a metered dose inhaler-spacer combination in acute obstructive pulmonary disease. Chest 1991;100:1300-5. [MEDLINE: 191330]

\section{Mandelberg 1997 \{published data only\}}

Mandelberg A, Chen E, Noviski N, Priel I. Nebulized wet aerosol treatment in emergency department - is it essential. Chest 1997;112:1501-5. 
Mandelberg 2000 \{published data only\}

Mandelberg A, Tsehori S, Houri S, Gilad E, Morag B, Priel IE. Is nebulized aerosol treatment necessary in a pediatric emergency department? Comparison with a metal spacer device for metered-dose inhaler. Chest 2000;117(5):1309-13.

\section{Morgan 1982 \{published data only\}}

Morgan MDL, Singh BV, Frame MH, Williams SJ. Terbutaline aerosol given through pear spacer in acute severe asthma. $B M J$ 1982;285:849-50.

\section{Newman 2002 \{published data only\}}

Newman KB, Milne S, Hamilton C, Hall K. A comparison of albuterol administered by metered-dose inhaler and spacer with albuterol by nebulizer in adults presenting to an urban emergency department with acute asthma. Chest 2002;121:1036-41.

\section{Rubilar 2000 \{published data only\}}

Rubilar L, Castro-Rodriguez JA, Girardi G. Randomized trial of salbutamol via metered-dose inhaler with spacer versus nebulizer for acute wheezing in children less than 2 years of age. Pediatric Pulmonology 2000;29:264-9.

\section{Shaikh 2001 \{published data only\}}

Shaikh GP, Pednekar S, Paidhungat AJ, Nabar ST, lyenger V, Khatri DP. A study of pulmonary functions, metabolic parameters and electro-cardiogram after salbutamol for bronchial asthma using two delivery systems. Indian Practitioner 2001;54(9):619-23.

\section{Shim 1984 \{published data only\}}

Shim CS, Williams MH. Effect of bronchodilator therapy administered by canister versus jet nebulizer. Journal of Allergy and Clinical Immunology 1984;73:387-90.

\section{Summer 1989 \{published data only\}}

Summer W, Elston R, Tharpe L, Nelson S, Haponik EF. Aerosol bronchodilator delivery methods. Relative impact on pulmonary function and cost of respiratory care. Archives of Internal Medicine 1989;149:618-23. [MEDLINE: 19920]

\section{Tarala 1980 \{published data only\}}

Tarala RA, Madsen BW, Paterson JW. Comparative efficacy of salbutamol by pressurized aerosol and wet nebulizer in acute asthma. British Journal of Clinical Pharmacology 1980;10:393-7.

\section{Vilarinho 2003 \{published data only\}}

Vilarinho LC, Cardeal Mendes CM, De Freitas Souza LS. Metereddose inhalers with home-made spacers versus nebulizers to treat moderate wheezing attacks in children. Jornal de Pediatria 2003;79(5):403-12. [PUBMED: 14557840]

\section{Wildhaber 1999 \{published data only\}}

Wildhaber JH, Dore ND, Wilson JM, Devadson SG, LeSouef PN. Inhalation therapy in asthma: nebulizer or pressurised metereddose inhaler with holding chamber? In vivo comparison of lung deposition in children. Journal of Pediatrics 1999;135(1):28-33.

\section{Additional references}

\section{BTS/SIGN 2011}

British Guideline on the Management of Asthma. A national clinical guideline. May 2008. Revised May 2011. British Thoracic Society www.brit-thoracic.org.uk and Scottish Intercollegiate Guidelines Network www.sign.ac.uk.

\section{GINA 2012}

Global Initiative for Asthma (GINA). The Global Strategy for Asthma Management and Prevention. www.ginasthma.org/ (accessed 1st June 2013) 2012.

\section{Gleeson 1988}

Gleeson JGA, Price JF. Nebuhaler technique. British Journal of Diseases of the Chest 1988;82:172-4.

\section{Higgins 2011}

Higgins JPT, Green S (editors). Cochrane Handbook for Systematic Reviews of Interventions Version 5.1.0 [updated March 2011]. The Cochrane Collaboration, 2011. Available from www.cochrane-handbook.org.

\section{Lipworth 1997}

Lipworth BJ, Clark DJ. Effects of airway calibre on lung delivery of nebulised salbutamol. Thorax 1997;52(12):1036-9.

\section{Newman 1984}

Newman SP, Millar AB, Lennard-Jones TR, Moran F, Clarke SW. Improvement of pressurised aerosol deposition with Nebuhaler spacer device. Thorax 1984;39:935-41.

\section{Osmond 2007}

Osmond MH, Gazarian M, Henry RL, Clifford TJ, Tetzlaff J. Barriers to metered-dose inhaler/spacer use in Canadian pediatric emergency departments: a national survey. Academic Emergency Medicine 2007;14(11):1106-13.

\section{Powell 2001}

Powell CV, Maskell GR, Marks MK, South M, Robertson CF. Successful implementation of spacer treatment guideline for acute asthma. Archives of Disease in Childhood 2001;84:142-6.

\section{Rodrigo 1996}

Rodrigo G, Rodrigo C. Metered dose inhaler Salbutamol treatment of asthma in the ED: a comparison of two doses with plasma levels. American Journal of Emergency Medicine 1996;14:144-50.

\section{Rowe 2007}

Rowe BH, Spooner CH, Ducharme FM, Bretzlaff JA, Bota GW. Corticosteroids for preventing relapse following acute exacerbations of asthma. Cochrane Database of Systematic Reviews 2007, Issue 3. [DOI: 10.1002/14651858.CD000195.pub2]

\section{Schuh 1989}

Schuh S, Parkin P, Rajan A, Canny G, Healy R, Reider M, et al. High- versus low-dose, frequently administered, nebulised albuterol in children with acute severe asthma. Pediatrics 1989;83:513-8. 


\section{Turner 1997}

Turner MO, Patel A, Ginsburg S, Fitzgerald JM. Bronchodilator delivery in acute airflow obstruction. Archives of Internal Medicine 1997;157:1736-44.

\section{References to other published versions of this review \\ Cates 2004}

Cates CJ, Bara A, Crilly JA, Rowe BH. Holding chambers versus nebulisers for beta-agonist treatment of acute asthma.
Cochrane Database of Systematic Reviews 2004, Issue 3. [DOI: 10.1002/14651858.CD000052]

\section{Cates 2006}

Cates CJ, Crilly JA, Rowe BH. Holding chambers (spacers) versus nebulisers for beta-agonist treatment of acute asthma. Cochrane Database of Systematic Reviews 2006, Issue 2. [DOI: 10.1002/14651858.CD000052.pub2]

* Indicates the major publication for the study

\section{CHARACTERISTICS OF STUDIES}

Characteristics of included studies [ordered by study ID]

\section{Ba 1989}

Methods
Baseline characteristics: Comparable but the Chamber group had significantly lower $\mathrm{FEV}_{1}$ at baseline $(P<0.02)$.

Intention-to-treat analysis: not used.
Setting: Hospital inpatients, Canada.

27 children aged 7 - 18 years old (average age 11.9).

Inclusion/exclusion criteria: Salbutamol nebulisers and IV aminophylline given on admission. 3 hours post- if $\mathrm{FVC}$ and $\mathrm{FEV}$, were still $<65 \%$ predicted value then included, if above excluded.

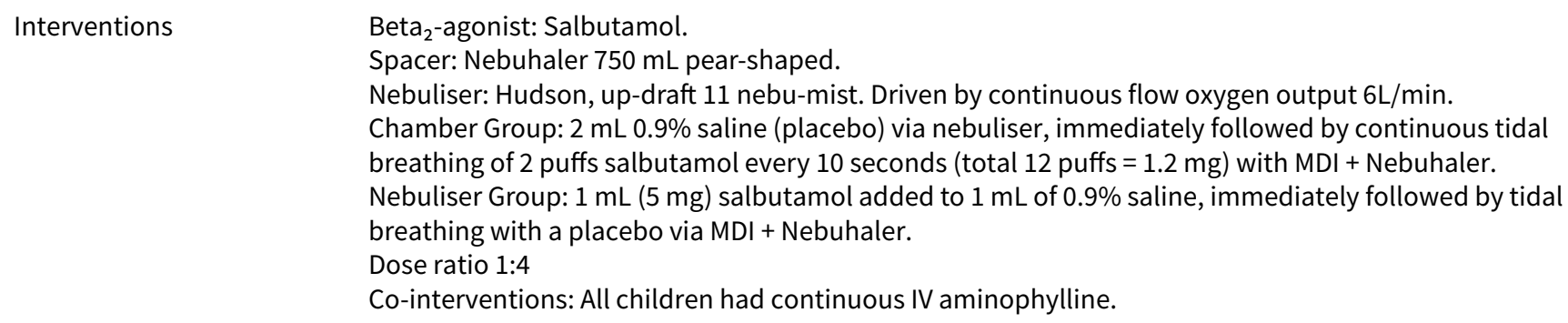

Outcomes

$\mathrm{FEV}_{1}$ and FVC, pulse, blood pressure, respiratory rate, side effects. Assessed at -11 mins (before) and 10, $30,60,90,120,180$ (after) inhalation from the MDI and spacer. Maximum change in FEV 1 and FVC from baseline.

Notes Lower baseline $\mathrm{FEV}_{1}$ in the spacer group may have contributed to the larger improvement from base-
line in this group.

\section{Risk of bias}

\begin{tabular}{lll}
\hline Bias & Authors' judgement & Support for judgement \\
\hline $\begin{array}{l}\text { Random sequence genera- } \\
\text { tion (selection bias) }\end{array}$ & Unclear risk & No details. \\
\hline $\begin{array}{l}\text { Allocation concealment } \\
\text { (selection bias) }\end{array}$ & Unclear risk & "subjects were entered in a double-blind randomised manner". \\
\hline $\begin{array}{l}\text { Blinding of participants } \\
\text { and personnel (perfor- } \\
\text { mance bias) }\end{array}$ & Low risk & Double-blind, double-dummy. \\
\begin{tabular}{l} 
All outcomes \\
\hline
\end{tabular}
\end{tabular}


Ba 1989 (Continued)

Blinding of outcome as- Low risk Double-blind, double-dummy. sessment (detection bias)

All outcomes

Incomplete outcome data Low risk $\quad$ "All patients completed the study". No withdrawals
(attrition bias)

Hospital Admission

\section{Batra 1997}

\begin{tabular}{ll}
\hline Methods & Baseline characteristics: comparable. \\
& Power analysis: 30 in each group designed to detect a $30 \%$ difference in response rate. \\
\hline Participants & Setting: India. Emergency Department. \\
& 60 children aged $1-12$ years (average age 4 years). PEF at presentation was under $40 \%$ predicted in the \\
& 16 children able to undergo this evaluation. \\
& Inclusion criteria: over 2 previous attacks of wheezing in response to allergens and exercise as well as \\
& infection. \\
& Exclusion criteria: TB, heart, liver, kidney or lung disease. Skeletal disorders. \\
\hline
\end{tabular}

Interventions $\quad$ Beta $_{2}$-agonist: Salbutamol.

Spacer: Volumatic (M/s Cipla) $750 \mathrm{~mL}$.

Dosage: 2 puffs $(200 \mathrm{mcg})$ given every 5 to 10 minutes for 60 minutes.

Nebuliser: no details.

Dosage: $0.15 \mathrm{mg} / \mathrm{kg}$ in $2.5 \mathrm{~mL}$ saline given 3 times at 20-minute intervals.

Co-interventions: all given humidified oxygen and none were given steroids.

\begin{tabular}{ll}
\hline Outcomes & Further treatment (?admission), PEF in 16 children, blood gases, symptoms score. \\
\hline Notes & $\begin{array}{l}\text { This trial was included as the mean age of the children was over } 2 \text { years old. No response from authors } \\
\text { to requests for further details. }\end{array}$
\end{tabular}

\section{Risk of bias}

\begin{tabular}{|c|c|c|}
\hline Bias & Authors' judgement & Support for judgement \\
\hline $\begin{array}{l}\text { Random sequence genera- } \\
\text { tion (selection bias) }\end{array}$ & Low risk & Computer-generated random numbers. \\
\hline $\begin{array}{l}\text { Allocation concealment } \\
\text { (selection bias) }\end{array}$ & Unclear risk & Information not available. \\
\hline $\begin{array}{l}\text { Blinding of participants } \\
\text { and personnel (perfor- } \\
\text { mance bias) } \\
\text { All outcomes }\end{array}$ & High risk & Open study. \\
\hline $\begin{array}{l}\text { Blinding of outcome as- } \\
\text { sessment (detection bias) } \\
\text { All outcomes }\end{array}$ & High risk & Open study. \\
\hline $\begin{array}{l}\text { Incomplete outcome data } \\
\text { (attrition bias) } \\
\text { Hospital Admission }\end{array}$ & Unclear risk & No mention of withdrawals. \\
\hline
\end{tabular}


Burrows 2004

\begin{tabular}{ll} 
Methods & $\begin{array}{l}\text { Baseline characteristics: not available } \\
\text { Intention-to-treat analysis: not available. }\end{array}$ \\
\hline Participants & $\begin{array}{l}\text { Southampton General Hospital, UK. } \\
29 \text { children aged } 1-6 \text { years admitted to hospital with moderate or severe asthma. } \\
\text { Inclusion criteria: moderate or severe asthma according to BTS criteria. } \\
\text { Exclusion criteria: details not available. }\end{array}$ \\
\hline
\end{tabular}

\begin{tabular}{ll}
\hline Interventions & $\begin{array}{l}\text { Beta }{ }_{2} \text {-agonist: Salbutamol. } \\
\text { Spacer: Volumatic (up to } 10 \text { puffs given). } \\
\text { Nebuliser: details not available, but dose of } 2.5 \text { to } 5 \mathrm{mg} \text { given at the discretion of the admitting physi- } \\
\text { cian. } \\
\text { Co-interventions: details not available. }\end{array}$ \\
\hline Outcomes & $\begin{array}{l}\text { Duration of admission to hospital, oxygen saturation, increase in heart rate, increase in respiratory rate, } \\
\text { drug costs. }\end{array}$
\end{tabular}

Notes

No SD data provided in abstract. Details for children over 2 years of age provided by the author.

\section{Risk of bias}

\begin{tabular}{lll}
\hline Bias & Authors' judgement & Support for judgement \\
\hline $\begin{array}{l}\text { Random sequence genera- } \\
\text { tion (selection bias) }\end{array}$ & Unclear risk & Described as randomised; other information not available. \\
\hline $\begin{array}{l}\text { Allocation concealment } \\
\text { (selection bias) }\end{array}$ & Unclear risk & Infomation not available. \\
\hline $\begin{array}{l}\text { Blinding of participants } \\
\text { and personnel (perfor- } \\
\text { mance bias) } \\
\text { All outcomes }\end{array}$ & High risk & Open study. \\
\hline $\begin{array}{l}\text { Blinding of outcome as- } \\
\text { sessment (detection bias) } \\
\text { All outcomes }\end{array}$ & High risk & Open study. \\
\hline $\begin{array}{l}\text { Incomplete outcome data } \\
\text { (attrition bias) } \\
\text { Hospital Admission }\end{array}$ & Unclear risk & Data provided on 25 out of 29 children \\
\hline
\end{tabular}

\section{Chong-Neto 2005}

\begin{tabular}{|c|c|}
\hline Methods & $\begin{array}{l}\text { Baseline characteristics: comparable. } \\
\text { Power calculation:carried out on the basis of a } 15 \% \text { difference in } \mathrm{FEV}_{1} \text { between groups. }\end{array}$ \\
\hline Participants & $\begin{array}{l}\text { Critiba, Brazil. } 24 \text {-hour emergency health unit. } \\
40 \text { children aged } 6 \text { - } 18 \text { years old. } 30 \text { of these were included in this review ( } 10 \text { in each arm as detailed be- } \\
\text { low). } \\
\text { Inclusion criteria: Acute asthma attacks. Children were able to use the devices and carry out lung func- } \\
\text { tion testing. } \\
\text { Exclusion criteria: History of cardiac and pulmonary diseases other than asthma, clinical score }<3 \text {, } \\
\text { forced expiratory flow in the first second }\left(\mathrm{FEV}_{1}\right) \text { less than } 20 \% \text { and greater than } 80 \% \text { of the predicted }\end{array}$ \\
\hline
\end{tabular}


Chong-Neto 2005 (Continued)

value. Smokers (> 10 packs of cigarettes/year), and children treated with short-acting and long-acting beta ${ }_{2}$-agonists in the last 24 hours, corticosteroids on the last 7 days, and also those receiving xanthines, were also excluded.

Beta 2 -agonist: Salbutamol (Albuterol).
Interventions
haled A: Aerochamber, $4 \times 100 \mathrm{mcg}$ separate actuations of salbutamol given at 30-second intervals, in-
Home-made Spacer: $500 \mathrm{~mL}$ plastic water bottle, 4 x $100 \mathrm{mcg}$ separate actuations of salbutamol giv-
en at 30 second intervals, inhaled using single deep breath per actuation. This was given 3 times at 20 -
minute intervals.
Nebuliser: Pari Jet, $0.15 \mathrm{mg} / \mathrm{kg}$ salbutamol given every 20 minutes in $3 \mathrm{~mL}$ saline driven by Proned ultra
compressor (air driven).
Dosage ratio: spacer:nebuliser = 1:12.5.
Co-interventions: not specified.
(The further 10 children treated with dry powder inhaler were not included in this review).

Outcomes

$\mathrm{FEV}_{1}$, admission to hospital, change in symptom score, increase in heart rate, tremor, nausea, vomiting, hypokalaemia. Full data provided by authors

\section{Notes}

\section{Risk of bias}

\begin{tabular}{lll}
\hline Bias & Authors' judgement & Support for judgement \\
\hline $\begin{array}{l}\text { Random sequence genera- } \\
\text { tion (selection bias) }\end{array}$ & Unclear risk & $\begin{array}{l}\text { Described as randomised; drawing of lots used but unclear how numbered lots } \\
\text { were drawn up. }\end{array}$ \\
\hline $\begin{array}{l}\text { Allocation concealment } \\
\text { (selection bias) }\end{array}$ & High risk & Children randomised themselves by drawing lots. \\
\hline $\begin{array}{l}\text { Blinding of participants } \\
\text { and personnel (perfor- } \\
\text { mance bias) }\end{array}$ & Low risk & Double-blind, double-dummy. \\
$\begin{array}{l}\text { All outcomes } \\
\begin{array}{l}\text { Blinding of outcome as- } \\
\text { sessment (detection bias) } \\
\text { All outcomes }\end{array}\end{array}$ & Low risk & Double-blind, double-dummy. \\
\hline $\begin{array}{l}\text { Incomplete outcome data } \\
\text { (attrition bias) } \\
\text { Hospital Admission }\end{array}$ & Low risk & All participants completed the study \\
\hline
\end{tabular}

\section{Chou 1995}

$\begin{array}{ll}\text { Methods } & \text { Baseline characteristics: comparable. } \\ \text { Intention to treat analysis: not required. }\end{array}$

Participants

New York. Urban paediatric Emergency Department.

152 children aged 2 years or older.

Mean PEF at presentation $56 \%$ and $53 \%$ in the treatment and control group.

Inclusion criteria: current wheeze and history of at least 2 episodes of wheezing.

Exclusion criteria: no participants were excluded from the study, but exclusion criteria included chronic illness, presenting oxygen saturation less than $90 \%$ or symptom score $>12$.

Interventions $\quad$ Beta ${ }_{2}$-agonist: Salbutamol (Albuterol).


Spacer: Aerochamber, $3 \times 90 \mathrm{mcg}$ actuations of salbutamol given every 20 minutes, inhaled using 5 normal breaths per actuation. (Mean 2.3 treatments given).

Nebuliser: Acorn II, $0.15 \mathrm{mg} / \mathrm{kg}$ salbutamol given every 20 minutes in $3 \mathrm{~mL}$ saline driven by oxygen at 6 $\mathrm{L}$ per minute (Mean 2.5 treatments given).

Co-interventions: oxygen was given to all participants with an oxygen saturation of less than $94 \%$ while breathing room air. Administration of steroids and other medication was at the discretion of the treating physician.

Admission to hospital, duration in emergency department, change in symptom score, final Peak Flow
(in children old enough to perform test), oxygen saturation, increase in heart rate, administration of
steroids.
steroids.

\section{Notes}

Standard deviation of results and details of randomisation obtained from author; SD of change in lung function estimated.

\section{Risk of bias}

\begin{tabular}{lll}
\hline Bias & Authors' judgement & Support for judgement \\
\hline $\begin{array}{l}\text { Random sequence genera- } \\
\text { tion (selection bias) }\end{array}$ & Low risk & Random numbers table. \\
\hline $\begin{array}{l}\text { Allocation concealment } \\
\text { (selection bias) }\end{array}$ & Low risk & Sealed opaque envelopes. \\
\hline $\begin{array}{l}\text { Blinding of participants } \\
\text { and personnel (perfor- } \\
\text { mance bias) } \\
\text { All outcomes }\end{array}$ & High risk & Open study. \\
\hline
\end{tabular}

Blinding of outcome as- High risk Open study.
sessment (detection bias) All outcomes

Incomplete outcome data $\quad$ Low risk $\quad$ All participants completed the study.
(attrition bias)

Hospital Admission

\begin{tabular}{ll}
\hline Coker 1995 & \\
\hline Methods & $\begin{array}{l}\text { Baseline characteristics: Comparable. } \\
\text { Intention-to-treat analysis: Not used. }\end{array}$ \\
\hline Participants & Setting: Hospital inpatients, Turkey. \\
& 36 children, 12 in each group; 2 groups considered. \\
& Mean age 10.33 (SD 1.15) (chamber), 11.75 (SD 1.60) (nebuliser). \\
& Inclusion Criteria: Children over 9 years, admitted with acute asthma crisis. \\
& Exclusion criteria: if received any medicine in the last 8 hours. \\
\hline Interventions & Beta -agonist: Salbutamol Spacer: 750 mL Volumatic spacer using tidal breathing. $200 \mathrm{mcg}$ (given twice \\
& with interval of 2 minutes in between). \\
& Nebuliser: Pari-inhaler boy (ultrasonic) nebuliser driven by compressed air. $0.05-0.1 \mathrm{mg} / \mathrm{kg}$ (max dose \\
of 2.5 mg) nebules. \\
Co-interventions: none.
\end{tabular}


Coker 1995 (Continued)

Outcomes Respiratory score (nasal flaring, cyanosis, retractions, wheezing), PEFR, respiratory rate, heart rate, blood pressure. All measured at 5, 15, 30, 240, and 360 ( 6 hours) minutes after treatment.

Notes

Confirmation of doses, gained from author as well as method of randomisation (alternation), withdrawals and dropouts and co-interventions.

3rd arm of this trial using MDI only was disregarded.

\section{Risk of bias}

\begin{tabular}{lll}
\hline Bias & Authors' judgement & Support for judgement \\
\hline $\begin{array}{l}\text { Random sequence genera- } \\
\text { tion (selection bias) }\end{array}$ & High risk & Alternate allocation. \\
\hline $\begin{array}{l}\text { Allocation concealment } \\
\text { (selection bias) }\end{array}$ & High risk & $\begin{array}{l}\text { Allocation by alternation at high risk of bias in terms of concealment of alloca- } \\
\text { tion. }\end{array}$ \\
\hline $\begin{array}{l}\text { Blinding of participants } \\
\text { and personnel (perfor- } \\
\text { mance bias) } \\
\text { All outcomes }\end{array}$ & High risk & Open study. \\
\hline
\end{tabular}

Blinding of outcome as- High risk Open study.

sessment (detection bias)

All outcomes

Incomplete outcome data Low risk

(attrition bias)

Hospital Admission

No withdrawals or dropouts reported in correspondence with the authors.

\section{Colacone 1993}

$\begin{array}{ll}\text { Methods } & \text { Baseline characteristics: comparable. } \\ \text { Intention-to-treat: not used in paper but carried out from data presented for hospital admissions } \\ \text { Power calculation: performed, estimated } 80 \% .\end{array}$
Power calculation: performed, estimated $80 \%$.

Participants Setting: Canada. Hospital Emergency Department.

80 adults mean age 41 (SD 18) and 43 (SD 19) years.

Mean FEV 1 (\% predicted) at presentation: Spacer 55\% (SD 15), nebuliser 54\% (SD 18).

Inclusion criteria: acute asthma, $\mathrm{FEV}_{1}<70 \%$ predicted, over 18 years old, able to perform spirometry.

Exclusion criteria: pregnancy, complicating medical illness, already given nebulised or parenteral be-

$\mathrm{ta}_{2}$-agonist in emergency department.

Beta ${ }_{2}$-agonist: Salbutamol (Albuterol).
Spacer: Aerochamber.
Dosage: $4 \times 100 \mathrm{mcg}$ puffs individually and inhaled by 1 slow inhalation at 1 minute intervals. Treat-
ment given every 30 minutes until maximum bronchodilation achieved.
Nebuliser: Disposable Updraft nebuliser.
Dosage: $2.5 \mathrm{mg}$ in $2 \mathrm{~mL}$ saline driven by oxygen at 5 to $8 \mathrm{~L} / \mathrm{min}$. Repeated every 30 minutes as above.
Dosage ratio: spacer:nebuliser $=1: 6$.
Co-interventions: steroids and aminophylline (stratified treatment arms).

Outcomes Symptom score, $\mathrm{FEV}_{1}$, heart rate, respiratory rate, presence of tremor. 
Colacone 1993 (Continued)

Notes

Cumulative dose-response curve showed a relative potency of 1:6 in favour of spacer. One participant was withdrawn from the spacer group due to clinical deterioration; included in review result as a hospital admission on intention-to-treat basis. Estimated SD for respiratory rate and pulse rate.

\section{Risk of bias}

\begin{tabular}{|c|c|c|}
\hline Bias & Authors' judgement & Support for judgement \\
\hline $\begin{array}{l}\text { Random sequence genera- } \\
\text { tion (selection bias) }\end{array}$ & Unclear risk & Not reported. \\
\hline $\begin{array}{l}\text { Allocation concealment } \\
\text { (selection bias) }\end{array}$ & Unclear risk & Not reported. \\
\hline $\begin{array}{l}\text { Blinding of participants } \\
\text { and personnel (perfor- } \\
\text { mance bias) } \\
\text { All outcomes }\end{array}$ & Low risk & Double-blind, double-dummy. \\
\hline $\begin{array}{l}\text { Blinding of outcome as- } \\
\text { sessment (detection bias) } \\
\text { All outcomes }\end{array}$ & Low risk & Double-blind, double-dummy. \\
\hline $\begin{array}{l}\text { Incomplete outcome data } \\
\text { (attrition bias) } \\
\text { Hospital Admission }\end{array}$ & Low risk & $\begin{array}{l}\text { Full description of dropouts allowing ITT analysis of hospital admission data. } \\
\text { One withdrawal from nebuliser group due to self-discharge and one from spac- } \\
\text { er group due to deterioration. }\end{array}$ \\
\hline
\end{tabular}

\section{Dewar 1999}

Methods $\quad 8 \%$ did not complete follow-up post-discharge, but did complete trial in hospital.

Baseline characteristics: comparable.

Intention-to-treat: not used.

Sample size: estimated from asthma admissions data from previous 2 years.

Participants Setting: Hospital inpatients, UK. 62 children aged 3 or above: mean age 6.9 years (chamber) 8 years (nebuliser).

Inclusion criteria: over 3 years, admitted with acute asthma.

Exclusion criteria: Children unable to use chamber mouthpiece effectively. Those requiring IV treatment. Those re-admitted during 5-month study period.

\section{Interventions $\quad$ Beta ${ }_{2}$-agonist: Salbutamol.}

Spacer: Large volume spacer (Volumatic).

Dosage: $100 \mathrm{mcg}$, up to 10 puffs one-hourly. Children and parents in the spacer group were instructed and supervised on the optimal use of the delivery device. They were also provided with a written treatment plan for managing acute asthma.

Nebuliser: jet nebuliser driven by oxygen $6-8 \mathrm{l} / \mathrm{min}$.

Dosage: $5 \mathrm{mg}$ salbutamol up to 1-hourly.

Co-interventions: All children received oral prednisolone at $2 \mathrm{mg} / \mathrm{kg}$ (max. dose $60 \mathrm{mg}$ ) on admission and repeated on subsequent mornings for 3 - 5 doses according to recovery.

Oxygen was administered by face mask or nasal prongs in children who after bronchodilator treatment had Ox. saturations of $<93 \%$.

Outcomes

Hospital length of stay, cost, asthma morbidity 2 weeks after discharge, frequency of re-admissions during the study period and following 12 months. 
Dewar 1999 (Continued)

Notes

All families given same discharge advice re: management of acute attacks, but seems only chamber group received a written treatment plan. No response from author to confirm this.

Participants lost to follow-up ignored: this can lead to bias.

\section{Risk of bias}

\begin{tabular}{lll}
\hline Bias & Authors' judgement & Support for judgement \\
\hline $\begin{array}{l}\text { Random sequence genera- } \\
\text { tion (selection bias) }\end{array}$ & Unclear risk & Described as randomised; no other details available. \\
\hline $\begin{array}{l}\text { Allocation concealment } \\
\text { (selection bias) }\end{array}$ & Low risk & Sequential presealed envelopes. \\
\hline $\begin{array}{l}\text { Blinding of participants } \\
\text { and personnel (perfor- } \\
\text { mance bias) }\end{array}$ & Unclear risk & Open study. \\
$\begin{array}{l}\text { All outcomes } \\
\begin{array}{l}\text { Blinding of outcome as- } \\
\text { sessment (detection bias) } \\
\text { All outcomes }\end{array}\end{array}$ & Unclear risk & \begin{tabular}{l} 
Open study. \\
\hline $\begin{array}{l}\text { Incomplete outcome data } \\
\text { (attrition bias) } \\
\text { Hospital Admission }\end{array}$
\end{tabular} \\
\hline
\end{tabular}

Dhuper 2008

\begin{tabular}{ll} 
Methods & $\begin{array}{l}\text { Baseline characteristics: more women in the Lite Aire group. } \\
\text { Intention-to-treat analysis: } 2 \text { withdrawn participants not included in the analysis. } \\
\text { Power calculation: none. }\end{array}$ \\
\hline Participants & Setting: New York. Emergency Department in 2 inner city hospitals in the Bronx. \\
& Median PEF at presentation: Spacer $220 \mathrm{~L} / \mathrm{min}$, Nebuliser $260 \mathrm{~L} / \mathrm{min}$. \\
& Inclusion criteria: acute asthma defined in NAEPP expert panel report II, as long as they could carry out \\
& PEF. \\
& Exclusion criteria: requiring intubation, more than 20 pack years of smoking, other co-existent systemic \\
& disease.
\end{tabular}

\begin{tabular}{l}
\hline Beta -agonist: Salbutamol. \\
Spacer: Lite Aire $160 \mathrm{~mL}$ collapsible card dual chamber spacer (disposable). \\
Dosage: 6 separate $90 \mathrm{mcg}$ actuations inhaled by tidal breathing . \\
Nebuliser: Cardinal Health Edison, NJ. Driving gas unclear. \\
Dosage: $2.5 \mathrm{mg}$ salbutamol. \\
Each group had repeated treatment once an hour for up to 6 hours. \\
Dosage Ratio: $1: 8$ (Spacer to Nebuliser). \\
Co-interventions: Not specified. Placebo given to each group using the other delivery device.
\end{tabular}

Change in PEF, symptoms and hospital admission. Secondary outcomes included length of stay, cost
and number of rescue treatments. Only hospital admission was used in this review as the other out-
comes were not normally distributed and were not suitable for meta-analysis.


Dhuper 2008 (Continued)

Risk of bias

\begin{tabular}{|c|c|c|}
\hline Bias & Authors' judgement & Support for judgement \\
\hline $\begin{array}{l}\text { Random sequence genera- } \\
\text { tion (selection bias) }\end{array}$ & Low risk & Randomisation table with block size of 4 used by pharmacist. \\
\hline $\begin{array}{l}\text { Allocation concealment } \\
\text { (selection bias) }\end{array}$ & Low risk & $\begin{array}{l}\text { All personnel involved in recruitment and medication delivery were blinded to } \\
\text { randomisation. }\end{array}$ \\
\hline $\begin{array}{l}\text { Blinding of participants } \\
\text { and personnel (perfor- } \\
\text { mance bias) } \\
\text { All outcomes }\end{array}$ & Low risk & Double-blind, double-dummy. \\
\hline $\begin{array}{l}\text { Blinding of outcome as- } \\
\text { sessment (detection bias) } \\
\text { All outcomes }\end{array}$ & Low risk & Double-blind, double-dummy. \\
\hline $\begin{array}{l}\text { Incomplete outcome data } \\
\text { (attrition bias) } \\
\text { Hospital Admission }\end{array}$ & Low risk & $\begin{array}{l}\text { One withdrawal in each group (withdrawn consent and self discharge against } \\
\text { medical advice). Fifteen participants excluded ( } 5 \text { did not fit inclusion criteria } \\
\text { and } 10 \text { did not consent) }\end{array}$ \\
\hline
\end{tabular}

Direkwatanachai 2008

Methods Baseline characteristics: Wood's asthma score below 4 in all group, no obvious baseline imbalance.
Intention-to-treat analysis: all participants seem to be included in the analysis.

Setting: 7 centres in Thailand. Emergency Departments and Outpatient clinics used.
68 children treated with MDI and spacer, 77 treated with nebuliser and 71 treated with Easyhaler (this
arm was not used in the review).
arm was not used in the review).

Mean ages $9.36(+/-2.68)$ years, $9.02(+/-2.57)$ in spacer and nebuliser groups.

Median PEF at presentation: No details.

Modified Wood's score: spacer 3.91 (1.22), nebuliser 3.57 (1.14). Maximum possible score is 7.

Inclusion criteria: children attending ED or Outpatients with an asthma exacerbation (mild or moderate severity).

Exclusion criteria: presence of other conditions, brittle asthma, severe exacerbation requiring intensive care or mechanical ventilation, allergy to salbutamol, repeated exacerbation within 7 days of entry into the study, or not able to use the DPI.

Interventions

Beta ${ }_{2}$-agonist: Salbutamol.

Spacer: Volumatic.

Dosage: 6 × $100 \mathrm{mcg}$ actuations (no details of separate actuations), repeated 3 times at 20-minute intervals.

Nebuliser: No details. Driving gas oxygen or compressed air at $6-8 \mathrm{~L} / \mathrm{min}$.

Dosage: $0.15 \mathrm{mg} / \mathrm{kg}$ salbutamol given up to maximum of $5 \mathrm{mg}$.

Each group had repeated treatment up to 3 doses.

Dosage Ratio: 1:8 for those given $5 \mathrm{mg}$ via nebuliser (Spacer to Nebuliser).

Co-interventions: None specified.

Third arm of study using Easyhaler was not considered for this review. 
Direkwatanachai 2008 (Continued)

Secondary outcomes: Admission to hospital, asthma revisit within 3 days, use of systemic steroids, adverse events, oxygen saturation, increase in heart rate.

Missing data only reported for adverse event data, where 22 missing from spacer group and 29 from nebuliser group.

Notes

No report of whether or not there were conflicts of interest, but Harn Thai Pharma provided all study medications and co-ordination of investigators meetings.

\section{Risk of bias}

\begin{tabular}{|c|c|c|}
\hline Bias & Authors' judgement & Support for judgement \\
\hline $\begin{array}{l}\text { Random sequence genera- } \\
\text { tion (selection bias) }\end{array}$ & Unclear risk & No details. \\
\hline $\begin{array}{l}\text { Allocation concealment } \\
\text { (selection bias) }\end{array}$ & Unclear risk & No details. \\
\hline $\begin{array}{l}\text { Blinding of participants } \\
\text { and personnel (perfor- } \\
\text { mance bias) } \\
\text { All outcomes }\end{array}$ & High risk & Open study. \\
\hline $\begin{array}{l}\text { Blinding of outcome as- } \\
\text { sessment (detection bias) } \\
\text { All outcomes }\end{array}$ & High risk & Open study. \\
\hline $\begin{array}{l}\text { Incomplete outcome data } \\
\text { (attrition bias) } \\
\text { Hospital Admission }\end{array}$ & Low risk & $\begin{array}{l}\text { No withdrawals. } \\
\text {. }\end{array}$ \\
\hline
\end{tabular}

Duarte 2002

Methods Baseline characteristics: no significant differences.

Intention-to-treat analysis: not described.

Power calculation based on $15 \mathrm{~L} /$ min difference in PEF.

Setting: Brazil. Emergency Room.
Participants 196 children aged $4-15$ years.
Mean PEF at presentation: Spacer $174 \mathrm{~L} / \mathrm{min}$, Nebuliser $173 \mathrm{~L} / \mathrm{min}$.
Inclusion criteria: 2 or more previous acute exacerbations, mild to moderate current attack (PEF $50 \%$ to
$79 \%$ of predicted).
Exclusion criteria: severe acute asthma (PEF under $50 \%$ predicted), patients unable to perform PEF, or
use delivery devices, patients who had used controller or rescue medication in the past 2 weeks, and
patients with complications (pneumothorax, pneumonia).

Interventions

Beta ${ }_{2}$-agonist: Salbutamol.

Spacer: $500 \mathrm{~mL}$ plastic mineral water bottle coated with detergent.

Dosage: 5 separate $100 \mathrm{mcg}$ actuations inhaled by tidal breathing for 20 seconds.

Nebuliser: Nevoni (Sao Paulo, Brazil). Driving gas oxygen at $6 \mathrm{~L} / \mathrm{min}$.

Dosage: $0.15 \mathrm{mg} / \mathrm{kg}$ salbutamol given up to maximum of $5 \mathrm{mg}$

Each group had repeated treatment up to 3 doses.

Dosage Ratio: 1:4 - 10 (Spacer to Nebuliser).

Co-interventions: Not specified. 
Duarte 2002 (Continued)

Outcomes PEF, Pulse oximetry, heart rate, respiratory rate, clinical score, duration in Emergency Room.

\begin{tabular}{ll}
\hline Notes & Participants were discharged from the study when the PEF rose to $80 \%$ predicted or higher. \\
& SD given for absolute values imputed for changes in heart rate and respiratory rate. PEF data not shown \\
& as \% predicted so not included.
\end{tabular}

\section{Risk of bias}

\begin{tabular}{|c|c|c|}
\hline Bias & Authors' judgement & Support for judgement \\
\hline $\begin{array}{l}\text { Random sequence genera- } \\
\text { tion (selection bias) }\end{array}$ & Unclear risk & Described as randomised; other information not available. \\
\hline $\begin{array}{l}\text { Allocation concealment } \\
\text { (selection bias) }\end{array}$ & Unclear risk & Information not available. \\
\hline $\begin{array}{l}\text { Blinding of participants } \\
\text { and personnel (perfor- } \\
\text { mance bias) } \\
\text { All outcomes }\end{array}$ & High risk & Participants not blinded. \\
\hline $\begin{array}{l}\text { Blinding of outcome as- } \\
\text { sessment (detection bias) } \\
\text { All outcomes }\end{array}$ & Low risk & Assessors blinded. \\
\hline $\begin{array}{l}\text { Incomplete outcome data } \\
\text { (attrition bias) } \\
\text { Hospital Admission }\end{array}$ & Low risk & No withdrawals. \\
\hline
\end{tabular}

Ferrés 1989

\begin{tabular}{ll} 
Methods & Baseline characteristics: no details. \\
& Intention-to-treat analysis: withdrawn participants not included in the analysis. \\
\hline Participants & Setting: Barcelona, Spain. Emergency Department in a hospital. \\
& 100 children. Mean age $8.6(+/-2.8)$ years. \\
& Median PEF at presentation: No details. \\
Inclusion criteria: children attending ED with an asthma exacerbation (no details of severity).
\end{tabular}

\begin{tabular}{ll}
\hline Interventions & Beta ${ }_{2}$-agonist: Salbutamol. \\
Spacer: $750 \mathrm{~mL}$ spacer. \\
Dosage: 25 puffs over 60 minutes. \\
Nebuliser: No details. \\
Dosage: $5 \mathrm{mg}$ salbutamol (possibly as a single dose). \\
Dosage Ratio: $1: 2$ (Spacer to Nebuliser). \\
Co-interventions: Not specified.
\end{tabular}

Outcomes PEF, pulse, respiratory rate, blood pressure and clinical score. Hospital admission data were obtained from correspondence with the author.

Notes Published in abstract only.

\section{Risk of bias}

\section{Bias \\ Authors' judgement Support for judgement}


Ferrés 1989 (Continued)

\begin{tabular}{lll}
$\begin{array}{l}\text { Random sequence genera- } \\
\text { tion (selection bias) }\end{array}$ & Unclear risk & No details. \\
\hline $\begin{array}{l}\text { Allocation concealment } \\
\text { (selection bias) }\end{array}$ & Unclear risk & No details. \\
\hline $\begin{array}{l}\text { Blinding of participants } \\
\text { and personnel (perfor- } \\
\text { mance bias) }\end{array}$ & High risk & Open study. \\
$\begin{array}{l}\text { All outcomes } \\
\begin{array}{l}\text { Blinding of outcome as- } \\
\text { sessment (detection bias) } \\
\text { All outcomes }\end{array}\end{array}$ & High risk & \\
\hline $\begin{array}{l}\text { Incomplete outcome data } \\
\text { (attrition bias) } \\
\text { Hospital Admission }\end{array}$ & High risk & Open study. \\
\hline
\end{tabular}

Freelander 1984

Methods $\quad$ Baseline characteristics: comparable, but mean age 9.1 and 6.1 in treatment and control groups.
Intention-to-treat analysis: none.

\begin{tabular}{ll}
\hline Participants & Setting: Australia. Accident and Emergency Department. \\
& 28 children aged $3-13$ years. \\
& Mean PEF(\% predicted) at presentation: spacer $55 \%$, nebuliser $65 \%$. \\
Inclusion criteria: no details. \\
Exclusion criteria: beta ${ }_{2}$-agonist in previous 2 hours. \\
Beta -agonist: Terbutaline. \\
Spacer: Nebuhaler. Dosage: 5 puffs $(1.25 \mathrm{mg})$ under $20 \mathrm{~kg}, 10 \mathrm{puffs}(2.5 \mathrm{mg})$ over $20 \mathrm{~kg}$. Details of inhala- \\
tion technique not given. (single treatment). \\
Nebuliser: Hudson driven by air at $6 \mathrm{~L} / \mathrm{minute}$. Dosage: $2.5 \mathrm{mg}$ in $2 \mathrm{~mL}$ saline under $20 \mathrm{~kg}, 5 \mathrm{mg}$ in $2 \mathrm{~mL}$ \\
saline over $20 \mathrm{~kg}$. (single treatment). \\
Dosage Ratio: spacer:nebuliser $=1: 2$. \\
Co-interventions: no details.
\end{tabular}

\begin{tabular}{ll}
\hline Outcomes & $\begin{array}{l}\text { Admission to hospital, change in symptom score, change in Peak Flow (in children old enough to per- } \\
\text { form test). }\end{array}$
\end{tabular}

Notes Some children had difficulty triggering the Nebuhaler valve. Estimated SD for Peak Flow.

\section{Risk of bias}

\begin{tabular}{lll}
\hline Bias & Authors' judgement & Support for judgement \\
\hline $\begin{array}{l}\text { Random sequence genera- } \\
\text { tion (selection bias) }\end{array}$ & Unclear risk & Described as randomised; other information not available. \\
\hline $\begin{array}{l}\text { Allocation concealment } \\
\text { (selection bias) }\end{array}$ & Unclear risk & Information not available. \\
\hline $\begin{array}{l}\text { Blinding of participants } \\
\text { and personnel (perfor- } \\
\text { mance bias) }\end{array}$ & High risk & Open study. \\
\hline
\end{tabular}


Freelander 1984 (Continued)

All outcomes

\begin{tabular}{lll}
$\begin{array}{l}\text { Blinding of outcome as- } \\
\text { sessment (detection bias) } \\
\text { All outcomes }\end{array}$ & High risk & Open study. \\
\hline $\begin{array}{l}\text { Incomplete outcome data } \\
\text { (attrition bias) } \\
\text { Hospital Admission }\end{array}$ & Unclear risk & No details of dropouts. \\
\hline
\end{tabular}

Hospital Admission

Hussein 2002

Methods Baseline characteristics: not stated
Participants Setting: Alexandria, Egypt. Outpatient department study of children presenting with acute asthma of moderate severity.
60 children aged 2 - 12 years.
Inclusion criteria: no details.
Exclusion criteria: no details.

\begin{tabular}{ll}
\hline Interventions & $\begin{array}{l}\text { Beta } 2 \text {-agonist: Salbutamol. } \\
\text { Spacer: 'Large volume', up to } 10 \text { puffs of salbutamol given as single dose. } \\
\text { Nebuliser: No details of nebuliser type, } 0.15 \mathrm{mg} / \mathrm{kg} \text { salbutamol given up to maximum of } 5 \mathrm{mg} \text {. Driving } \\
\text { gas not specified. } \\
\text { Co-interventions: Not specified. }\end{array}$ \\
\hline Outcomes & $\begin{array}{l}\text { Admission to hospital, change in symptom score, pulmonary function, oxygen saturation, increase in } \\
\text { heart rate. } 4 \text { admissions in nebuliser group and } 3 \text { in holding chamber group. Symptoms, oxygen satura- } \\
\text { tion and lung function reported as similar in both groups, and mean heart rate higher in the nebuliser } \\
\text { group. }\end{array}$
\end{tabular}

Notes

\section{Risk of bias}

\begin{tabular}{lll}
\hline Bias & Authors' judgement & Support for judgement \\
\hline $\begin{array}{l}\text { Random sequence genera- } \\
\text { tion (selection bias) }\end{array}$ & Unclear risk & Described as randomised; other information not available. \\
\hline $\begin{array}{l}\text { Allocation concealment } \\
\text { (selection bias) }\end{array}$ & Unclear risk & Information not available. \\
\hline $\begin{array}{l}\text { Blinding of participants } \\
\text { and personnel (perfor- } \\
\text { mance bias) }\end{array}$ & High risk & Open study. \\
$\begin{array}{l}\text { All outcomes } \\
\text { Blinding of outcome as- } \\
\text { sessment (detection bias) } \\
\begin{array}{l}\text { All outcomes } \\
\text { Incomplete outcome data }\end{array}\end{array}$ & High risk & Onclear risk study. \\
$\begin{array}{l}\text { (attrition bias) } \\
\text { Hospital Admission }\end{array}$ & & No details of dropouts reported. \\
\hline
\end{tabular}


Idris 1993

$\begin{array}{ll}\text { Methods } & \text { Baseline characteristics: comparable. } \\ \text { Intention-to-treat: not applicable. } \\ \text { Power calculation: performed, predicted } 90 \% \text { power to detect } 12 \% \text { difference in lung function. }\end{array}$

\begin{tabular}{ll}
\hline Participants & Setting: USA. Hospital Emergency Rooms. \\
& 35 participants aged $10-45$ years, mean age 23 (spacer) and 25 (nebuliser). \\
& Mean PEF (\% predicted) at presentation: spacer 34 (SD 14), nebuliser 37 (SD 17). \\
Inclusion criteria: acute asthma. \\
Exclusion criteria: angina, respiratory failure, COPD, smoking for 10 pack years or more, unable to per- \\
form spirometry. \\
Beta ${ }_{2}$-agonist: Salbutamol (Albuterol). \\
Spacer: InspirEase. \\
Dosage: $4 \times 90$ mcg puffs 1 puff every minute, inhaled by 1 slow inhalation. Treatment repeated every \\
30 minutes until FEV ${ }_{1}$ was $80 \%$ predicted or participant asymptomatic or 6 treatments given. \\
Nebuliser: T Up-Draft II Nebu-U-Mist. \\
Dosage: $2.5 \mathrm{mg}$ in 2 mL saline, driven by oxygen at $5 \mathrm{~L} /$ min. Treatment repeated every 30 minutes until \\
FEV ${ }_{1}$ was $80 \%$ predicted or participant asymptomatic or 6 treatments given. \\
Dosage ratio: spacer/nebuliser = 1:7. Mean dose to max response with spacer 1.11 (SD 0.64) mg, nebu- \\
liser 7.63 (SD 3.9) mg. \\
Co-interventions: parenteral steroids usually given within 1 hour of discharge.
\end{tabular}

Outcomes Further treatment (?admission), duration in emergency department, Peak Flow, FEV ${ }_{1}, \mathrm{FVC}$, heart rate, respiratory rate, administration of steroids.

\begin{tabular}{|c|c|c|}
\hline Notes & $\begin{array}{l}\text { Results include } \% \text { max } \\
30 \% \text { predicted. }\end{array}$ & num response (see footnotes). Separate analysis for participants with $\mathrm{FEV}_{1}<$ \\
\hline \multicolumn{3}{|l|}{ Risk of bias } \\
\hline Bias & Authors' judgement & Support for judgement \\
\hline $\begin{array}{l}\text { Random sequence genera- } \\
\text { tion (selection bias) }\end{array}$ & Unclear risk & Described as randomised; other information not available. \\
\hline $\begin{array}{l}\text { Allocation concealment } \\
\text { (selection bias) }\end{array}$ & Unclear risk & Information not available. \\
\hline $\begin{array}{l}\text { Blinding of participants } \\
\text { and personnel (perfor- } \\
\text { mance bias) } \\
\text { All outcomes }\end{array}$ & Low risk & Double-blind, double-dummy. \\
\hline $\begin{array}{l}\text { Blinding of outcome as- } \\
\text { sessment (detection bias) } \\
\text { All outcomes }\end{array}$ & Low risk & Double-blind, double-dummy. \\
\hline $\begin{array}{l}\text { Incomplete outcome data } \\
\text { (attrition bias) } \\
\text { Hospital Admission }\end{array}$ & Unclear risk & No details reported of withdrawals \\
\hline
\end{tabular}


Jamalvi 2006 (Continued)

Participants
Setting: Emergency Room of the National Institute of Child Health in Karachi, Pakistan, from October 2000 to March 2001.

150 children (aged 6 months to 15 years). $76 \%$ were classified as having severe asthma attack (24\% mild or moderate).

Inclusion criteria: acute asthma.

Exclusion criteria: children requiring intensive care management, PEFR values under $20 \%$ or over $70 \%$ predicted, oxygen saturation under $90 \%$ in room air, or receiving daily systemic corticosteroids for more than 2 weeks before being seen in the emergency room.

Beta ${ }_{2}$-agonist: Salbutamol (Albuterol).

Spacer: Babyhaler for younger children and spacer with mouthpiece for older children.

Dosage: 2 x $100 \mathrm{mcg}$ repeated 3 times at 20-minute intervals.

Nebuliser: Type 2 Fleam Nuova S.P.A., Bresia, Italy.

Dosage: $0.3 \mathrm{mg} / \mathrm{kg}$ with $2 \mathrm{~mL}$ Normal Saline repeated 3 times at 20-minute intervals.

Dosage ratio: unknown.

Co-interventions: none reported.

Outcomes

Admission to hospital, pulse, respiratory rate, BP, dyspnoea, cyanosis, wheeze, PEFR, clinical score, measured at 10 minutes, 20 minutes and 2 hours after completion of treatment.

Notes

No details are given for mean age in each group or how many children were able to perform PEFR. Trial included as mean age is almost certainly over 2 years old.

\section{Risk of bias}

\begin{tabular}{|c|c|c|}
\hline Bias & Authors' judgement & Support for judgement \\
\hline $\begin{array}{l}\text { Random sequence genera- } \\
\text { tion (selection bias) }\end{array}$ & Unclear risk & No details. \\
\hline $\begin{array}{l}\text { Allocation concealment } \\
\text { (selection bias) }\end{array}$ & Unclear risk & No details. \\
\hline $\begin{array}{l}\text { Blinding of participants } \\
\text { and personnel (perfor- } \\
\text { mance bias) } \\
\text { All outcomes }\end{array}$ & Unclear risk & Open study. \\
\hline $\begin{array}{l}\text { Blinding of outcome as- } \\
\text { sessment (detection bias) } \\
\text { All outcomes }\end{array}$ & Unclear risk & Open study. \\
\hline $\begin{array}{l}\text { Incomplete outcome data } \\
\text { (attrition bias) } \\
\text { Hospital Admission }\end{array}$ & Low risk & $\begin{array}{l}\text { All participants accounted for in admission data. Three participants were ex- } \\
\text { cluded form the study. }\end{array}$ \\
\hline
\end{tabular}

Kerem 1993

\begin{tabular}{ll}
\hline Methods & $\begin{array}{l}\text { Baseline characteristics: comparable. } \\
\text { Intention-to-treat analysis: not stated. }\end{array}$ \\
\hline Participants & Setting: Canada. Emergency Department. \\
& 33 children aged 6 - 14 years old. \\
& Mean FEV 1 (\% predicted) at presentation: spacer $40 \%$, nebuliser $40 \%$.
\end{tabular}


Kerem 1993 (Continued)

Inclusion criteria: not stated.

Exclusion criteria: critically ill, $\mathrm{FEV}_{1}<20 \%$ or $>70 \%$, oxygen saturation in air $<92 \%$, systemic steroids given for more than 2 weeks.

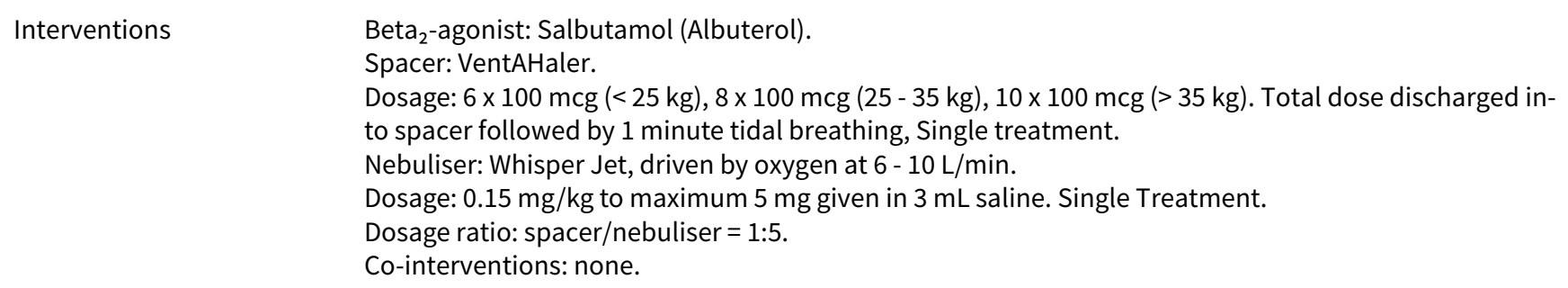

\begin{tabular}{lll}
\hline Bias & Authors' judgement & Support for judgement \\
\hline $\begin{array}{l}\text { Random sequence genera- } \\
\text { tion (selection bias) }\end{array}$ & Unclear risk & Described as randomised; no other information available. \\
\hline $\begin{array}{l}\text { Allocation concealment } \\
\text { (selection bias) }\end{array}$ & Low risk & Assigned by research pharmacist.. \\
\hline $\begin{array}{l}\text { Blinding of participants } \\
\text { and personnel (perfor- } \\
\text { mance bias) }\end{array}$ & Low risk & Double-blind, double-dummy. \\
$\begin{array}{l}\text { All outcomes } \\
\text { Blinding of outcome as- } \\
\text { sessment (detection bias) } \\
\begin{array}{l}\text { All outcomes } \\
\text { Incomplete outcome data }\end{array}\end{array}$ & Low risk & Double-blind, double-dummy. \\
$\begin{array}{l}\text { (attrition bias) } \\
\text { Hospital Admission }\end{array}$ & & \\
\hline
\end{tabular}

Leversha 2000

Methods Baseline characteristics: comparable for asthma severity.
Intention-to-treat: performed.

Power calculation: powered to detect a difference of 1.25 in clinical score between groups.

Participants Setting: New Zealand. Emergency Department in children's hospital. 60 children aged 1 - 4 years; mean age 36 months (spacer) and 32 months. (nebuliser). 66\% had received oral steroids in the previous 24 hours in each group. Inclusion criteria: Known history of asthma with a clinical score of greater than 3, presenting to ED with acute asthma.

Exclusion criteria: bronchodilator given in the hour before presentation or requiring immediate admission to intensive care unit. Also co-existing medical condition (such as pneumonia).

\begin{tabular}{ll}
\hline Interventions & Beta ${ }_{2}$-agonist: Salbutamol (Albuterol). \\
& Spacer: Aerochamber.
\end{tabular}


Dosage: $6 \times 100$ mcg puffs inhaled separately by tidal breathing. Repeated every 20 minutes for a maximum of 6 treatments.

Nebuliser: Marquest bowl with Hudson face mask.

Dosage: $2.5 \mathrm{mg}$ every 20 minutes for a maximum of 6 treatments, driven by wall oxygen.

Double-dummy methodology so placebo given by the other route to all children.

Co-interventions: supplemental oxygen if $\mathrm{SaO}_{2}$ less than $92 \%$ and oral prednisone unless child had received oral steroids in past 24 hours.

Dosage ratio: spacer/nebuliser $=1: 4$.

Outcomes

Admission to hospital. pulse, respiratory rate, $\mathrm{SaO}_{2}$, clinical score, tremor and hyperactivity measured 20 minutes after each treatment and 60 minutes after final treatment.

Notes

Data in the paper is only provided for the results 20 minutes after the first treatment.

One of the tables of data in the paper was inconsistent and has since been corrected. The data used in

the review for heart rate and respiratory rate has been provided by Dr Leversha.

\section{Risk of bias}

\begin{tabular}{|c|c|c|}
\hline Bias & Authors' judgement & Support for judgement \\
\hline $\begin{array}{l}\text { Random sequence genera- } \\
\text { tion (selection bias) }\end{array}$ & Unclear risk & Described as randomised; no other information available. \\
\hline $\begin{array}{l}\text { Allocation concealment } \\
\text { (selection bias) }\end{array}$ & Low risk & Pharmacy generated. \\
\hline $\begin{array}{l}\text { Blinding of participants } \\
\text { and personnel (perfor- } \\
\text { mance bias) } \\
\text { All outcomes }\end{array}$ & Low risk & Double-blind, double-dummy. \\
\hline $\begin{array}{l}\text { Blinding of outcome as- } \\
\text { sessment (detection bias) } \\
\text { All outcomes }\end{array}$ & Low risk & Double-blind, double-dummy. \\
\hline $\begin{array}{l}\text { Incomplete outcome data } \\
\text { (attrition bias) } \\
\text { Hospital Admission }\end{array}$ & Low risk & $\begin{array}{l}\text { Three children were withdrawn, but were included in the analysis, (one from } \\
\text { nebulizer group refused the nebulizer but was treated with spacer and dis- } \\
\text { charged, and one from each group refused treatment and was admitted). }\end{array}$ \\
\hline
\end{tabular}

\section{Lin 1995}

$\begin{array}{ll}\text { Methods } & \text { Baseline characteristics: comparable. } \\ \text { Intention-to-treat: not performed. } \\ \text { Power calculation: not stated. }\end{array}$

\begin{tabular}{|c|c|}
\hline Participants & $\begin{array}{l}\text { Setting: Taiwan. Hospital Emergency Department and paediatric allergy clinic. } \\
111 \text { children aged } 5 \text { - } 16 \text { years. } \\
\text { Mean PEF (\% predicted) at presentation: spacer } 57 \text { (SD 20)\%, nebuliser } 60 \text { (SD 21)\%. } \\
\text { Inclusion criteria: acute asthma or acute exacerbation of chronic asthma. } \\
\text { Exclusion criteria: inhaled beta }{ }_{2} \text {-agonist in previous } 6 \text { hours, unable to perform spirometry, pneumo- } \\
\text { nia, congestive heart failure, foreign body aspiration, bronchopulmonary dysplasia. }\end{array}$ \\
\hline
\end{tabular}

Interventions Beta 2 -agonist: Terbutaline.

Spacer: Aerochamber.

Dosage: $3 \times 0.25 \mathrm{mg}$ puffs, each inhaled by 3 deep breaths. Single treatment.

Nebuliser: Pulmo-Aide.

Dosage: $2.5 \mathrm{mg}$ in $2 \mathrm{~mL}$ saline, driven by air at $8 \mathrm{~L} / \mathrm{min}$. Single treatment. 
Lin 1995 (Continued)

Dosage ratio: spacer/nebuliser $=$ 1:3.5.

Co-interventions: not stated.

\begin{tabular}{ll}
\hline Outcomes & $\begin{array}{l}\text { Measured at } 15 \text { minutes after the start of treatment: symptom score, Peak, FEV }{ }_{1} \text {, FVC, oxygen satura- } \\
\text { tion, heart rate. }\end{array}$ \\
\hline Notes & Mean fall in $\mathrm{SaO}_{2}$ at 15 minutes was 0.47 (SD 1.93)\% in the nebuliser group, compared to a mean rise of \\
& $0.58(\mathrm{SD} 1.72) \%$ in spacer group. Estimated SD for Peak Flow and pulse rate.
\end{tabular}

\section{Risk of bias}

\begin{tabular}{lll}
\hline Bias & Authors' judgement & Support for judgement \\
\hline $\begin{array}{l}\text { Random sequence genera- } \\
\text { tion (selection bias) }\end{array}$ & High risk & Alternate weeks. \\
\hline $\begin{array}{l}\text { Allocation concealment } \\
\text { (selection bias) }\end{array}$ & High risk & Investigators had foreknowledge of treatment group assignment. \\
\hline $\begin{array}{l}\text { Blinding of participants } \\
\text { and personnel (perfor- } \\
\text { mance bias) } \\
\text { All outcomes }\end{array}$ & High risk & Open study. \\
\hline $\begin{array}{l}\text { Blinding of outcome as- } \\
\text { sessment (detection bias) } \\
\text { All outcomes }\end{array}$ & High risk & \\
\hline $\begin{array}{l}\text { Incomplete outcome data } \\
\text { (attrition bias) } \\
\text { Hospital Admission }\end{array}$ & Unclear risk & Open study. \\
\hline
\end{tabular}

\section{Maldano-Alanis 1997}

\begin{tabular}{|c|c|}
\hline Methods & $\begin{array}{l}\text { Baseline characteristics: similar. } \\
\text { Power calculation: "approximately } 90 \% " .\end{array}$ \\
\hline Participants & $\begin{array}{l}\text { Setting: ER Hospital Infantil de Mexico Fredrico Gomez. } \\
42 \text { children aged } 6 \text { - } 15 \text {; baseline } \mathrm{FEV}_{1} 69 \% \text { (spacer) and } 77 \% \text { (nebuliser). } \\
\text { Inclusion criteria: } \mathrm{FEV}_{1} \text { of } 60 \% \text { to } 80 \% \text { of predicted value. } \\
\text { Exclusion criteria: use of xanthines, steroids, beta } \text {-agonists or antihistamines. Unable to use spirome- }_{\text {ter. }}\end{array}$ \\
\hline Interventions & $\begin{array}{l}\text { Beta }{ }_{2} \text {-agonist: Salbutamol. } \\
\text { Spacer: unknown. } \\
\text { Dosage: } 2 \text { x } 100 \mathrm{mcg} \text { twice } 20 \text { minutes apart. } \\
\text { Nebuliser: Hudson driven by oxygen, dose } 0.15 \mathrm{mg} / \mathrm{kg} \text { up to maximum of } 5 \mathrm{mg} \text { made up to } 5 \mathrm{~mL} \text { with } \\
\text { saline. Given twice } 20 \text { minutes apart. } \\
\text { Dose ratio up to } 1: 25 .\end{array}$ \\
\hline Outcomes & $\begin{array}{l}\mathrm{FEV}_{1} \text { at } 1,2,3,4,5,6 \text { hours. } \\
\text { Pulse rate rise. } \\
\text { Symptoms using Silverman-Anderson scale. }\end{array}$ \\
\hline Notes & $\begin{array}{l}\text { No SDs reported. After } 3 \text { hours following treatment the spacer group } \mathrm{FEV}_{1} \text { had fallen significantly more } \\
\text { than the nebuliser group. }\end{array}$ \\
\hline
\end{tabular}


Maldano-Alanis 1997 (Continued)

Risk of bias

\begin{tabular}{lll}
\hline Bias & Authors' judgement & Support for judgement \\
\hline $\begin{array}{l}\text { Random sequence genera- } \\
\text { tion (selection bias) }\end{array}$ & Unclear risk & Information not available. \\
\hline $\begin{array}{l}\text { Allocation concealment } \\
\text { (selection bias) }\end{array}$ & Unclear risk & Information not available. \\
\hline $\begin{array}{l}\text { Blinding of participants } \\
\text { and personnel (perfor- } \\
\text { mance bias) }\end{array}$ & High risk & Open study. \\
All outcomes & \\
\hline $\begin{array}{l}\text { Blinding of outcome as- } \\
\text { sessment (detection bias) } \\
\text { All outcomes }\end{array}$ & High risk & Open study. \\
\hline $\begin{array}{l}\text { Incomplete outcome data } \\
\text { (attrition bias) } \\
\text { Hospital Admission }\end{array}$ & Low risk & No withdrawals. \\
\hline
\end{tabular}

Morley 1988

Methods Baseline Characteristics: Comparable.

Intention-to-treat: not used.

Participants Setting: Hospital inpatients, New Jersey, USA.

28 adults, admitted with acute status asthmaticus. Mean age of 34.8 (15.9) chamber group, 31.3 (19.0)

nebuliser group.

Inclusion criteria: acute status asthmaticus, admitted after failing multiple trials of either subcutaneous or nebulised beta $_{2}$-agonists.

Exclusion criteria: A smoking history of $>5$ packs a year of cigarettes, emphysema, respiratory acidosis on admission, or pregnant. Unstable coronary insufficiency, recent myocardial infarction, or cardiac arrhythmia were also excluded.

Interventions $\quad$ Beta ${ }_{2}$-agonist: Salbutamol (Albuterol).

Spacer: InspirEase, Key Pharmaceutical.

Dosage: 3 inhalations (90 micrograms /inhalation) each separated by 5-minute intervals. Received every 4 hours.

Nebuliser: Acorn 2 nebulizer (Marquest Medical Products Inc, Englewood, CO).

Dosage: $0.5 \mathrm{~mL}(2.5 \mathrm{mg})$ albuterol and $2.0 \mathrm{~mL}$ normal saline solution nebulised over $15 \mathrm{~min}$ period. Received every 6 hours while awake.

Additional therapies: All participants received standard IV dosages of aminophylline. IV methylprednisolone was administered as recommended by Haskell et al.

No oral beta ${ }_{2}$-agonists were used.

(Group 3 received $15 \mathrm{mg}$ nebulised metaproterenol).

Outcomes

Spirometric improvement ( $\mathrm{FEV}_{1}$ and $\left.\mathrm{FVC}\right)$ 15, 30, 60, 120, 180, 240 minutes following the 1st beta ${ }_{2}$-agonist treatment (best of 2 recorded), duration of hospital stay (discharge criteria: free of wheezing on auscultation and no exertional dyspnoea when walking on ground level), daily rates of spirometric improvement during course of hospitalisation (performed once in morning and once in afternoon at similar times every day,- just prior to treatment). Following 3rd day spirometry was not performed again until discharge (calculations were based on assumption of discharge day at day 6). 
Morley 1988 (Continued)

Notes
Trial begins from initial beta ${ }_{2}$-agonist dose given once admitted (at least 4 hours after last dose given in

$A+E$.) No data of how much given before trial commenced.

3 rd arm of this trial ignored as different beta ${ }_{2}$-agonist used.

\section{Risk of bias}

\begin{tabular}{|c|c|c|}
\hline Bias & Authors' judgement & Support for judgement \\
\hline $\begin{array}{l}\text { Random sequence genera- } \\
\text { tion (selection bias) }\end{array}$ & High risk & Alternate allocation. \\
\hline $\begin{array}{l}\text { Allocation concealment } \\
\text { (selection bias) }\end{array}$ & High risk & Investigators had foreknowledge of treatment group assignment. \\
\hline $\begin{array}{l}\text { Blinding of participants } \\
\text { and personnel (perfor- } \\
\text { mance bias) } \\
\text { All outcomes }\end{array}$ & High risk & Open study. \\
\hline $\begin{array}{l}\text { Blinding of outcome as- } \\
\text { sessment (detection bias) } \\
\text { All outcomes }\end{array}$ & High risk & Open study. \\
\hline $\begin{array}{l}\text { Incomplete outcome data } \\
\text { (attrition bias) } \\
\text { Hospital Admission }\end{array}$ & Low risk & $\begin{array}{l}\text { No withdrawals (however } 2 \text { participants' data were excluded from daily rates } \\
\text { of spirometric improvement as spirometric analysis required was not complet- } \\
\text { ed). }\end{array}$ \\
\hline
\end{tabular}

\section{Morrone 1990}

$\begin{array}{ll}\text { Methods } & \begin{array}{l}\text { Baseline characteristics: comparable. } \\ \text { Intention to treat: not applicable. }\end{array}\end{array}$

\begin{tabular}{ll}
\hline Participants & Setting: Brazil. Mobile clinic. \\
& 44 adults, 36 women, 8 men. \\
& Mean PEF (\% predicted) at presentation: $180 \mathrm{~L} / \mathrm{min}$ (\% predicted not stated). \\
& Inclusion criteria: PEF $120-200 \mathrm{~L} / \mathrm{min}$ at presentation. \\
& Exclusion criteria: not stated.
\end{tabular}

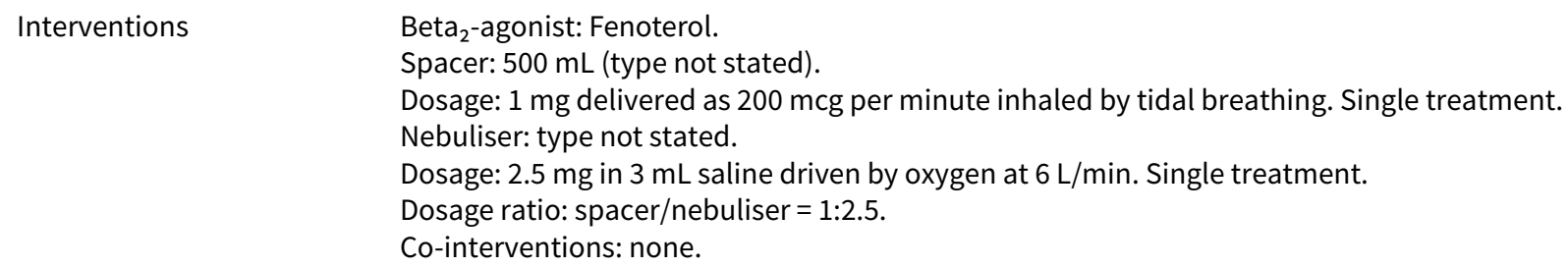

Outcomes Peak Flow. Actual readings changed to \% predicted by assuming expected peak flow of $500 \mathrm{l} / \mathrm{min}$ as original data have been lost.

Notes Only the first part of this study compared spacer against nebuliser, the second part of the cross-over was not analysed due the high likelihood of contamination. Estimated SD for Peak Flow. Data were measured from graph published in errata. (Revista Paulista de Medicina 1990;108:98)

\section{Risk of bias}


Morrone 1990 (Continued)

Bias Authors' judgement Support for judgement

Random sequence genera- High risk Alternate allocation.

tion (selection bias)

Allocation concealment High risk Investigators had foreknowledge of treatment group assignment.

(selection bias)

Blinding of participants High risk Open study.
and personnel (perfor-
mance bias)
All outcomes

$\begin{array}{lll}\text { Blinding of outcome as- } & \text { High risk } & \text { Open study. } \\ \text { sessment (detection bias) } & \end{array}$

All outcomes

Incomplete outcome data Low risk $\quad$ All participants completed the study.
(attrition bias)

Hospital Admission

\section{Parkin 1995}

$\begin{array}{ll}\text { Methods } & \text { Baseline characteristics: Clinical asthma score was 5.7 chamber, } 4.8 \text { nebuliser }(P=0.02) \text { therefore an } \\ \text { adjusted mean used. } \\ \text { Intention-to-treat analysis: performed. } \\ \text { Power analysis: } 30 \text { in each group designed to detect approximately } 90 \% \text { difference in asthma score. }\end{array}$

\begin{tabular}{ll}
\hline Participants & Setting: Hospital inpatients (after stabilisation in Emergency Department), Canada. \\
& 60 children aged 1 - 5 years old ( 2.9 years mean) Inclusion criteria: moderate acute asthma. \\
& Exclusion criteria: not stated.
\end{tabular}

Interventions $\quad$ Beta ${ }_{2}$-agonist: Salbutamol and ipratropium bromide.

Spacer: Aerochamber $140 \mathrm{~mL}$ cylindrical with one-way valve and mask.

Dosage: Salbutamol 400 mcg for those < 12 kg, 500 mcg for 12 - 16 kg, 600 mcg 16 kg or over. All had 40

mcg ipratropium bromide also.

Nebulizer: Driven by compressed air, using a face mask

Dosage: Salbutamol $0.15 \mathrm{mg} / \mathrm{kg} /$ dose (maximum $5 \mathrm{mg}$ ) + ipratropium bromide 125 micrograms, sus-

pended in $3 \mathrm{~mL}$ of $0.9 \%$ saline over 15 minutes.

Drug ratio: Assumed drug ratio of nebuliser: MDI and chamber as 1:4.

Co-interventions: All participants received systemic corticosteroids.(IV vs or oral).

Outcomes
Primary outcome: 10 -point clinical asthma score measuring:
respiratory rate, wheezing, indrawing, observed dyspnoea, and inspiratory to expiratory ratio (Mea-
sured up to $60 \mathrm{hrs).}$
Secondary measures:
Time to discharge, time to 4-hourly dosing interval, total number of inhaled doses required, nurses as-
sessed ease of administration and participants tolerance on a Likert scale, parents reported symptoms
at 7 and 14 days post-discharge.

Notes

Single blinding may have been appropriate due to age of participants i.e. little placebo effect in 1 - 5 year olds.

Trial sponsored by Aerochamber and MDI companies.

Study included as mean age over 2 years.

\section{Risk of bias}

Holding chambers (spacers) versus nebulisers for beta-agonist treatment of acute asthma (Review) 
Parkin 1995 (Continued)

\begin{tabular}{|c|c|c|}
\hline Bias & Authors' judgement & Support for judgement \\
\hline $\begin{array}{l}\text { Random sequence genera- } \\
\text { tion (selection bias) }\end{array}$ & Unclear risk & Information not available. \\
\hline $\begin{array}{l}\text { Allocation concealment } \\
\text { (selection bias) }\end{array}$ & Unclear risk & Information not available. \\
\hline $\begin{array}{l}\text { Blinding of participants } \\
\text { and personnel (perfor- } \\
\text { mance bias) } \\
\text { All outcomes }\end{array}$ & High risk & Participants not blinded. \\
\hline $\begin{array}{l}\text { Blinding of outcome as- } \\
\text { sessment (detection bias) } \\
\text { All outcomes }\end{array}$ & Low risk & Assessor blinded. \\
\hline $\begin{array}{l}\text { Incomplete outcome data } \\
\text { (attrition bias) } \\
\text { Hospital Admission }\end{array}$ & Unclear risk & $\begin{array}{l}\text { No details of withdrawals ( } 9 \text { children from spacer group crossed over to nebu- } \\
\text { liser). Four failures (stopping criteria not given). }\end{array}$ \\
\hline
\end{tabular}

\section{Pendergast 1989}

\begin{tabular}{ll} 
Methods & Baseline characteristics: compared. \\
Intention-to-treat: not done. \\
& Power calculation: estimated 80\%. \\
\hline Participants & Setting: Australia. Acute presentation at Children's Hospital. \\
& 27 children aged 3 to 6.8 years. \\
& Mean symptom score at presentation: $2.13(0.49)$ and $2.30(0.46)$ in spacer groups, $2.42(0.55)$ in nebulis- \\
& er group. \\
& Inclusion criteria: not stated. \\
& Exclusion criteria: not stated.
\end{tabular}

$\begin{array}{ll}\text { Interventions } & \text { Beta }{ }_{2} \text {-agonist: Terbutaline. } \\ & \text { Spacer: Nebuhaler. } \\ & \text { Dosage: Low-dose group }=1 \text { puff }(0.25 \mathrm{mg}) \text { per } 5 \mathrm{~kg} . \\ & \text { High-dose group }=2 \text { puffs }(0.5 \mathrm{mg}) \text { per } 5 \mathrm{~kg} \text {. Each dose (bursts of } 3 \text { or } 4 \text { puffs) inhaled with } 2 \text { breaths and } \\ \text { then a minute of tidal breathing. } & \\ & \text { Nebuliser: Unicorn. } \\ & \text { Dosage: } 0.2 \mathrm{mg} \text { per kg weight in } 2 \mathrm{~mL} \text { saline (max } 5 \mathrm{mg}) \text { driven by oxygen at } 6 \mathrm{~L} / \mathrm{min} . \\ & \text { Dosage ratio: spacer/nebuliser }=4: 1 \text { or } 2: 1 . \\ & \text { Co-interventions: none. }\end{array}$

\begin{tabular}{ll}
\hline Outcomes & Admission to hospital, symptom score. \\
\hline Notes & Withdrawals: 3 from spacer group due to inability to co-operate and 1 from spacer group due to clinical \\
& deterioration. \\
& Vague descriptions of outcome ("no difference" between number in each group needing a second \\
& treatment or admission to hospital). \\
& Lower-dose spacer group showed a trend to deterioration on score between 30 and 60 minutes after \\
& treatment which did not reach significance $(P=0.05)$.
\end{tabular}

\section{Risk of bias}


Pendergast 1989 (Continued)

Random sequence genera- Unclear risk Information not available. tion (selection bias)

Allocation concealment
(selection bias)

Blinding of participants High risk Open study.
and personnel (perfor-
mance bias)

\begin{tabular}{lll}
$\begin{array}{l}\text { Blinding of outcome as- } \\
\text { sessment (detection bias) } \\
\text { All outcomes }\end{array}$ & High risk & Open study. \\
\hline $\begin{array}{l}\text { Incomplete outcome data } \\
\text { (attrition bias) } \\
\text { Hospital Admission }\end{array}$ & High risk & $\begin{array}{l}4 \text { children withdrawn from spacer group (3 could not use the nebuhaler and } \\
\text { one deteriorated in clinical state). }\end{array}$ \\
\hline
\end{tabular}

Ploin 2000

Methods Baseline characteristics: $\mathrm{SaO}_{2}$ was significantly lower in the Holding Chamber group.
Intention-to-treat analysis: yes.

Power analysis: yes.
Participants Setting: Paediatric Emergency Department of 2 teaching hospitals in Lyon, France.
64 children recruited aged 1 - 5 years; mean ages 24.8 months (chamber) and 25.5 months (nebuliser). 1 child excluded from the analysis due to being randomised twice.
Inclusion criteria: Acute wheezing in children with at least 3 episodes of wheezing or 3 episodes with a family history of atopy, eczema or asthma.
Exclusion criteria: $\mathrm{SaO}_{2}$ less than $90 \%$, inhaled or systemic steroids within the past 24 hours, or underly- ing chronic disease.

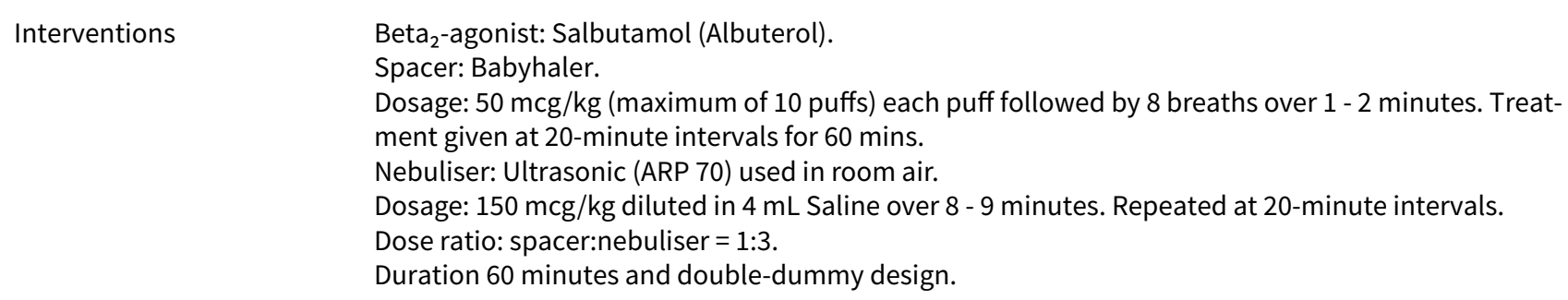

\section{Risk of bias}

\begin{tabular}{lll}
\hline Bias & Authors' judgement & Support for judgement \\
\hline $\begin{array}{ll}\text { Random sequence genera- } \\
\text { tion (selection bias) }\end{array}$ & Low risk & Blocks of 4 computer-generated. \\
\hline
\end{tabular}


Ploin 2000 (Continued)

$\begin{aligned} & \text { Allocation concealment } \\ & \text { (selection bias) }\end{aligned}$ Unclear risk No information.

Blinding of participants Low risk Double-blind, double-dummy.
and personnel (perfor-
mance bias)
All outcomes

\begin{tabular}{lll}
\hline $\begin{array}{l}\text { Blinding of outcome as- } \\
\text { sessment (detection bias) }\end{array}$ & Low risk \\
All outcomes & \\
\hline $\begin{array}{l}\text { Incomplete outcome data } \\
\text { (attrition bias) } \\
\text { Hospital Admission }\end{array}$ & "Nowe of the patients dropped out of the study". \\
\hline
\end{tabular}

\section{Raimondi 1997}

\begin{tabular}{ll}
\hline Methods & Baseline characteristics: comparable. \\
Intention-to-treat: not stated. \\
Power calculation: carried out but in the event the study was underpowered.
\end{tabular}

Participants Setting: Argentina, Emergency Department at Hospital Ferrer, Buenos Aires.

27 adults with asthma according to the ATS criteria.

Inclusion criteria: severe asthma attack defined as $\mathrm{FEV}_{1}<1$ litre or $<30 \%$ predicted.

Exclusion criteria: smokers, pregnant, pneumothorax, pneumonia or in extremis.

Beta ${ }_{2}$-agonist: Salbutamol (Albuterol).
Spacer: Aerochamber.
Dosage: 400 mcg delivered as 4 separate actuations, each one inhaled by 3 deep breaths and repeated
at 60 -second intervals. Repeated every 30 minutes for 2 hours and then hourly until the 6 th hour.
Nebuliser: Puritan-Bennett Raindrop.
Dosage: 5 mg given over 5 to 10 minutes and repeated as above.
Dose Ratio: spacer:nebuliser = 1:13.
Co-interventions: all participants received 8 mg Dexamethasone IV and were given oxygen.

Outcomes $\quad \mathrm{FEV}_{1}$, hospital admission.

\section{Notes}

\section{Risk of bias}

\begin{tabular}{lll}
\hline Bias & Authors' judgement & Support for judgement \\
\hline $\begin{array}{l}\text { Random sequence genera- } \\
\text { tion (selection bias) }\end{array}$ & Unclear risk & Information not available \\
\hline $\begin{array}{l}\text { Allocation concealment } \\
\text { (selection bias) }\end{array}$ & Unclear risk & Information not available \\
\hline $\begin{array}{l}\text { Blinding of participants } \\
\text { and personnel (perfor- } \\
\text { mance bias) }\end{array}$ & High risk & Open study \\
All outcomes & & \\
\hline
\end{tabular}


Raimondi 1997 (Continued)

$\begin{array}{lll}\text { Blinding of outcome as- } & \text { High risk } & \text { Open study } \\ \text { sessment (detection bias) } & & \end{array}$

All outcomes

Incomplete outcome data Low risk No withdrawals
(attrition bias)
Hospital Admission

Rao 2002

\begin{tabular}{ll} 
Methods & $\begin{array}{l}\text { Baseline characteristics: comparable. } \\
\text { Intention-to-treat: not stated. } \\
\text { Power calculation: not stated. }\end{array}$ \\
\hline Participants & Setting: Pakistan, Hospital Emergency Departments in 2 hospitals in Karachi. \\
& 50 adults aged $18-62$, (mean age 40$),$ with acute asthma exacerbation (moderate to severe according \\
& to BTS guidelines). Initial mean PEF 27 - 30\% predicted. \\
& Inclusion criteria: acute asthma defined by signs, symptoms and peak flow readings. \\
& Exclusion criteria: unable to perform spirometry, history of respiratory failure, COPD, IHD or arrhyth- \\
& mias, smoking history of more than 10 pack years or pregnancy.
\end{tabular}

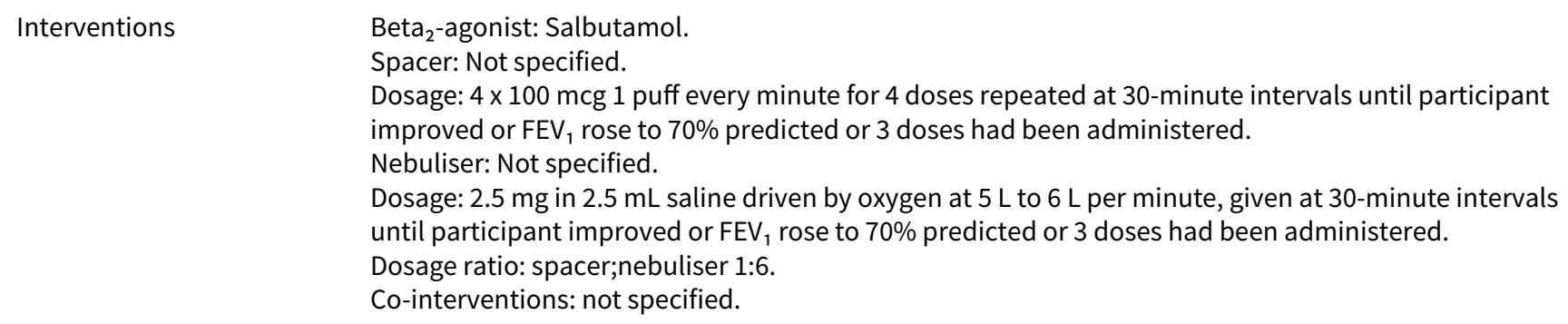

\section{Risk of bias}

\begin{tabular}{lll}
\hline Bias & Authors' judgement & Support for judgement \\
\hline $\begin{array}{l}\text { Random sequence genera- } \\
\text { tion (selection bias) }\end{array}$ & Unclear risk & Information not available. \\
\hline $\begin{array}{l}\text { Allocation concealment } \\
\text { (selection bias) }\end{array}$ & Unclear risk & Information not available. \\
\hline $\begin{array}{l}\text { Blinding of participants } \\
\text { and personnel (perfor- } \\
\text { mance bias) }\end{array}$ & Low risk & Double-blind, double-dummy. \\
$\begin{array}{l}\text { All outcomes } \\
\text { Blinding of outcome as- } \\
\text { sessment (detection bias) } \\
\begin{array}{l}\text { All outcomes } \\
\hline \hline\end{array}\end{array}$ & Low risk & \\
\hline
\end{tabular}


Rao 2002 (Continued)

Incomplete outcome data Unclear risk No details of dropouts.

(attrition bias)

Hospital Admission

\section{Robertson 1998}

\begin{tabular}{ll}
\hline Methods & Baseline characteristics: comparable. \\
Intention-o-treat analysis: children requiring additional therapy were excluded from further analysis. \\
Power analysis: none.
\end{tabular}

Participants Setting: Australia, multicentre in Emergency Departments.

155 children recruited aged 4 - 12 years, 147 evaluable.

Inclusion criteria: PEF under 70\% predicted (aged over 7 ) or clinical score of $>4$ out of 12 .

Exclusion criteria: critically ill, concurrent cardiopulmonary disease or given bronchodilator within the

last hour.

Beta -agonist: Salbutamol.
Spacer: Volumatic.
Dosage: $600 \mathrm{mcg}$ (under $25 \mathrm{~kg}$ ) and $1200 \mathrm{mcg}$ (over $25 \mathrm{~kg}$ ) given in bursts of 3 puffs with $15 \mathrm{~seconds}$ of
tidal breathing.
Nebuliser: AVA-NEB Hudson.
Dosage: $2.5 \mathrm{mg}(<25 \mathrm{~kg}$ ) or $5 \mathrm{mg}(>25 \mathrm{~kg})$ in $2.5 \mathrm{~mL}$ saline driven by oxygen at 8 to $10 \mathrm{~L} / \mathrm{min}$.
Dose ratio spacer:nebuliser $=1: 4.2$.
Single-dose study.

\begin{tabular}{ll}
\hline Outcomes & Withdrawal to further treatment, PEF, pulse, blood pressure, tremor and symptom score. \\
\hline Notes & 15 withdrawals in spacer group and 12 in nebuliser group. Both groups showed $1 \%$ increase in $\mathrm{SaO}_{2}$. \\
& The study was funded by Allen and Hanbury's. \\
\hline
\end{tabular}

\section{Risk of bias}

\begin{tabular}{|c|c|c|}
\hline Bias & Authors' judgement & Support for judgement \\
\hline $\begin{array}{l}\text { Random sequence genera- } \\
\text { tion (selection bias) }\end{array}$ & Unclear risk & Information not available. \\
\hline $\begin{array}{l}\text { Allocation concealment } \\
\text { (selection bias) }\end{array}$ & Unclear risk & Information not available. \\
\hline $\begin{array}{l}\text { Blinding of participants } \\
\text { and personnel (perfor- } \\
\text { mance bias) } \\
\text { All outcomes }\end{array}$ & Low risk & Double-blind, double-dummy. \\
\hline $\begin{array}{l}\text { Blinding of outcome as- } \\
\text { sessment (detection bias) } \\
\text { All outcomes }\end{array}$ & Low risk & Double-blind, double-dummy. \\
\hline $\begin{array}{l}\text { Incomplete outcome data } \\
\text { (attrition bias) } \\
\text { Hospital Admission }\end{array}$ & Unclear risk & $\begin{array}{l}27 \text { withdrawals due to inadequate response ( } 15 \text { from spacer group and } 12 \\
\text { from nebuliser group). }\end{array}$ \\
\hline
\end{tabular}


Rodrigo 1993

\begin{tabular}{|c|c|}
\hline Methods & $\begin{array}{l}\text { Baseline characteristics: comparable. } \\
\text { Intention-to-treat: not stated. } \\
\text { Power calculation: not stated. }\end{array}$ \\
\hline Participants & $\begin{array}{l}\text { Setting: Uruguay. Hospital Emergency Room. } \\
97 \text { adults aged } 18-50 . \\
\text { Mean PEF(\% predicted) at presentation: } 32 \% \text { in each group. } \\
\text { Inclusion criteria: "criteria of the American Thoracic Society". } \\
\text { Exclusion criteria: PEF or FEV }{ }_{1}>50 \% \text { predicted pregnancy, history of chronic cough, other medical dis- } \\
\text { ease. }\end{array}$ \\
\hline Interventions & $\begin{array}{l}\text { Beta }{ }_{2} \text {-agonist: Salbutamol. } \\
\text { Spacer: Volumatic. } \\
\text { Dosage: } 4 \text { x } 100 \mathrm{mcg} \text { every } 10 \text { minutes, each puff inhaled with } 2 \text { deep inhalations from the spacer. } \\
\text { Nebuliser: Ava-Neb. } \\
\text { Dosage: } 1.5 \mathrm{mg} \text { in } 4 \mathrm{~mL} \text { saline driven by oxygen at } 8 \mathrm{~L} / \mathrm{min} \text { at } 15 \text {-minute intervals. } \\
\text { Dosage ratio: spacer:nebuliser }=1: 2 \text {, (mean total dose } 5.61 \mathrm{mg} / 11.8 \mathrm{mg} \text { ). } \\
\text { Co-interventions: oxygen by nasal prongs } 4 \mathrm{~L} / \text { min given to all participants. All participants received oral } \\
\text { steroids at discharge. }\end{array}$ \\
\hline
\end{tabular}

Outcomes Admission to hospital, duration in Emergency Department, Peak Flow, FEV 1 , FVC, heart rate, develop-
ment of tremor.

$\begin{array}{ll}\text { Notes } & \text { Separate analysis was performed on those participants admitted and those with FEV } 1<0.9 \mathrm{~L}_{1} \text { Estimated } \\ \text { SD for final Peak Flow in holding chamber group. }\end{array}$

\section{Risk of bias}

\begin{tabular}{|c|c|c|}
\hline Bias & Authors' judgement & Support for judgement \\
\hline $\begin{array}{l}\text { Random sequence genera- } \\
\text { tion (selection bias) }\end{array}$ & Low risk & Random numbers table. \\
\hline $\begin{array}{l}\text { Allocation concealment } \\
\text { (selection bias) }\end{array}$ & Unclear risk & Infomation not available. \\
\hline $\begin{array}{l}\text { Blinding of participants } \\
\text { and personnel (perfor- } \\
\text { mance bias) } \\
\text { All outcomes }\end{array}$ & Low risk & Double-blind, double-dummy. \\
\hline $\begin{array}{l}\text { Blinding of outcome as- } \\
\text { sessment (detection bias) } \\
\text { All outcomes }\end{array}$ & Low risk & Double-blind, double-dummy. \\
\hline $\begin{array}{l}\text { Incomplete outcome data } \\
\text { (attrition bias) } \\
\text { Hospital Admission }\end{array}$ & Unclear risk & No details of dropouts reported. \\
\hline
\end{tabular}

\section{Rodrigo 1998}

\begin{tabular}{ll}
\hline Methods & Baseline characteristics: comparable. \\
& Intention-to-treat: no data. \\
& Power calculation: powered to detect a $36 \%$ difference $(0.6$ litres) in FEV
\end{tabular}


22 adults aged 18 - 50 with acute asthma exacerbation (all met ATS criteria for asthma). Initial mean PEF $30 \%$ predicted and $\mathrm{SaO}_{2} 95 \%$.

Inclusion criteria: PEF and $\mathrm{FEV}_{1}$ both below $50 \%$ predicted at presentation.

Exclusion criteria: other chronic disease or pregnancy.

Beta ${ }_{2}$-agonist: Salbutamol.
Spacer: Volumatic.
Dosage: $4 \times 100 \mathrm{mcg}$ every 10 minutes, $(2.4 \mathrm{mg}$ per hour $)$
Nebuliser: Hudson T Up-draft flow rate $8 \mathrm{~L} / \mathrm{min}$.
Dosage: $1.5 \mathrm{mg}$ in $4 \mathrm{~mL}$ saline driven by compressed air at $8 \mathrm{~L} / \mathrm{min}$ at 15 -minute intervals.
Dosage ratio: spacer;nebuliser $=1: 2.3$.
Co-interventions: oxygen was allowed in the protocol if $\mathrm{SaO}_{2}$ fell below $90 \%$ but was not required in
any participant. $500 \mathrm{mg}$ of hydrocortisone was given to all participants with a poor response after 3
hours.

\section{Outcomes}

$\mathrm{FEV}_{1}, \mathrm{PEF}, \mathrm{QTC}$ interval, $\mathrm{SaO}_{2}$ (arterial oxygen saturation) every 30 minutes. Potassium and Salbutamol blood levels at start and 3 hours.

\begin{tabular}{ll}
\hline Notes & Neither group showed a deterioration in oxygen saturation and no oxygen was needed in this study. \\
& Final plasma salbutamol was $10.1(\mathrm{SD} 1.6 \mathrm{ng} / \mathrm{m})$ in spacer group and $14.4(\mathrm{SD} 2.3 \mathrm{ng} . \mathrm{mL}) \mathrm{in}$ nebuliser \\
group.
\end{tabular}

\section{Risk of bias}

\begin{tabular}{lll}
\hline Bias & Authors' judgement & Support for judgement \\
\hline $\begin{array}{l}\text { Random sequence genera- } \\
\text { tion (selection bias) }\end{array}$ & Low risk & Random numbers table. \\
\hline $\begin{array}{l}\text { Allocation concealment } \\
\text { (selection bias) }\end{array}$ & Unclear risk & Information not available. \\
\hline $\begin{array}{l}\text { Blinding of participants } \\
\text { and personnel (perfor- } \\
\text { mance bias) }\end{array}$ & Low risk & Double-blind, double-dummy. \\
All outcomes & \\
\hline $\begin{array}{l}\text { Blinding of outcome as- } \\
\text { sessment (detection bias) } \\
\text { All outcomes }\end{array}$ & Low risk & Double-blind, double-dummy. \\
\hline $\begin{array}{l}\text { Incomplete outcome data } \\
\text { (attrition bias) } \\
\text { Hospital Admission }\end{array}$ & Unclear risk & No details of dropouts reported. \\
\hline
\end{tabular}

\section{Rodriguez 1999}

$\begin{array}{ll}\text { Methods } & \begin{array}{l}\text { Baseline characteristics: similar in the } 2 \text { groups. } \\ \text { Intention-to-treat: not required. }\end{array}\end{array}$

Power calculation: not stated.
Participants
Setting: Colombia. Hospital Emergency Department (University Hospital of San Ignatio).
69 adults (56 women) mean age 39 years. Mean PEF at baseline $186 \mathrm{~L} / \mathrm{min}, \mathrm{SD} 78 \mathrm{~L} / \mathrm{min}$ (spacer group) and $179 \mathrm{~L} / \mathrm{min}$ SD $89 \mathrm{~L} / \mathrm{min}$ (nebuliser group).
Asthma severity: 26 mild asthma attack, 20 moderate and 23 severe.
Inclusion criteria: "acute exacerbation of asthma" defined clinically. 
Rodriguez 1999 (Continued)

Exclusion criteria: no details.

\begin{tabular}{ll}
\hline Outcomes & $\begin{array}{l}\text { Admission to hospital. heart rate, respiratory rate, PEF, every } 20 \text { minutes and at } 120 \text { minutes. Blood } \\
\text { gases at baseline and } 120 \text { minutes. }\end{array}$ \\
\hline Notes & $\begin{array}{l}\text { Unpublished data supplied by authors. SDs provided for each time period, and imputed to the change } \\
\text { measurements. }\end{array}$
\end{tabular}

Beta ${ }_{2}$-agonist: Salbutamol.

Spacer: Volumatic.

Dosage: 4 x 100 mcg every 10 minutes for 1 hour (no details of inhalation method).

Nebuliser: type not stated.

Dosage: 2.5 mg every 20 minutes for 1 hour.

Dosage ratio: spacer:nebuliser $=1: 3$.

Co-interventions: not stated.

\section{Risk of bias}

\begin{tabular}{|c|c|c|}
\hline Bias & Authors' judgement & Support for judgement \\
\hline $\begin{array}{l}\text { Random sequence genera- } \\
\text { tion (selection bias) }\end{array}$ & Low risk & Random number table. \\
\hline $\begin{array}{l}\text { Allocation concealment } \\
\text { (selection bias) }\end{array}$ & High risk & Allocation not concealed. \\
\hline $\begin{array}{l}\text { Blinding of participants } \\
\text { and personnel (perfor- } \\
\text { mance bias) } \\
\text { All outcomes }\end{array}$ & High risk & Participants were not blinded. \\
\hline $\begin{array}{l}\text { Blinding of outcome as- } \\
\text { sessment (detection bias) } \\
\text { All outcomes }\end{array}$ & Low risk & Outcomes evaluated by an observer blinded to the treatment allocated. \\
\hline $\begin{array}{l}\text { Incomplete outcome data } \\
\text { (attrition bias) } \\
\text { Hospital Admission }\end{array}$ & Low risk & No withdrawals reported on correspondence with the authors \\
\hline
\end{tabular}

\section{Salzman 1989}

Methods Baseline characteristics: comparable, except baseline FEV ${ }_{1}$ lower in the spacer group.

Intention-to-treat: not done.

Power calculation: not stated.

\begin{tabular}{ll}
\hline Participants & Setting: USA. Hospital Emergency Department. \\
& 44 adults. Spacer group mean age 32.5 yrs (SD 12.5), nebuliser group mean age 28 yrs (SD 10.3). \\
& Mean FEV 1 (\% predicted) at presentation: Spacer 26\% (SD 12.1\%), nebuliser 33\% (SD 16\%). \\
& Inclusion criteria: acute asthma FEV $<$ < $50 \%$ predicted. \\
& Exclusion criteria: COPD, pneumothorax, depression, $\mathrm{PaCO}_{2}>40$, ventilation required.
\end{tabular}

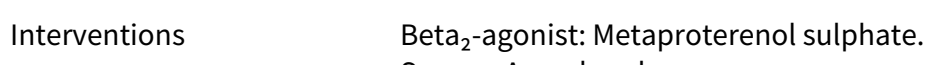

Spacer: Aerochamber.

Dosage: $3 \times 0.65 \mathrm{mg}$ puffs each 5 minutes apart. Single treatment. No details of breathing method.

Nebuliser: type not stated.

Dosage: $15 \mathrm{mg}$ in $2 \mathrm{~mL}$ saline over 10 minutes. Single treatment. Dosage ratio: spacer:nebuliser = 1:8. 
Salzman 1989 (Continued)

Co-interventions: none.

Outcomes Admission to hospital, FEV 1 , FVC, heart rate, respiratory rate.

Notes Rise in $\mathrm{FEV}_{1}(\%$ predicted) calculated from data given in paper.

\section{Risk of bias}

\begin{tabular}{lll}
\hline Bias & Authors' judgement & Support for judgement \\
\hline $\begin{array}{l}\text { Random sequence genera- } \\
\text { tion (selection bias) }\end{array}$ & Low risk & Random number table. \\
\hline $\begin{array}{l}\text { Allocation concealment } \\
\text { (selection bias) }\end{array}$ & Unclear risk & Information not available. \\
\hline $\begin{array}{l}\text { Blinding of participants } \\
\text { and personnel (perfor- } \\
\text { mance bias) } \\
\text { All outcomes }\end{array}$ & Low risk & Double-blind, double-dummy. \\
\hline $\begin{array}{l}\text { Blinding of outcome as- } \\
\text { sessment (detection bias) } \\
\text { All outcomes }\end{array}$ & Low risk & Double-blind, double-dummy. \\
\hline $\begin{array}{l}\text { Incomplete outcome data } \\
\text { (attrition bias) } \\
\text { Hospital Admission }\end{array}$ & Low risk & \begin{tabular}{l} 
\\
\hline
\end{tabular}
\end{tabular}

\section{Sannier 2007}

$\begin{array}{ll}\text { Methods } & \text { Excluded: } 106 \text { of } 185 \text { children presenting during working hours were excluded. } \\ \text { Withdrawals: none for the initial study, } 6 \text { families were lost to longer-term follow-up. } \\ \text { Baseline characteristics: comparable, except imbalance in respiratory rate. }\end{array}$

Setting: Paediatric Emergency Department in France .
79 children aged $4-15$ years (mean age 9 years). 40 participants allocated to nebuliser and 39 allocated
to spacer.
Inclusion criteria:severe acute exacerbation of asthma (Bishop score $>6$ or $\mathrm{SaO}_{2}$ less than $\left.92 \%\right)$. The de-
finition of severe asthma was understood as an acute attack developing over more than 24 hours (or
nocturnally), non-responsive to beta ${ }_{2}$-agonist therapy (initiated prior to hospital presentation), or oc-
curring in spite of maintenance treatment with inhaled steroids (+/- beta -agonist), or recurring within $_{2}$ ( 1 month of oral steroid treatment and an attack occurring in a child with previous treatment in inten-
sive care for acute asthma.
was separated by 8 - 10 valve movements). Nebuliser: Mininebuliser AIRVIE, Peters, Bobigny, France. Driven by oxygen at $6 \mathrm{~L} / \mathrm{min}$. Dosage: $0.15 \mathrm{mg} / \mathrm{kg}$ salbutamol in $4 \mathrm{~mL}$ saline every 20 minutes for 6 doses (minimum $1.5 \mathrm{mg}$ to maximum $5 \mathrm{mg}$ per dose).

Dosage ratio: spacer:nebuliser $=1: 3$ to $1: 5$.

Co-interventions: all participants received oral steroids at the start of treatment. 
Sannier 2007 (Continued)

Notes

Baseline imbalance in respiratory rate noted, which may have contributed to the larger fall in the nebuliser group.

\section{Risk of bias}

\begin{tabular}{lll}
\hline Bias & Authors' judgement & Support for judgement \\
\hline $\begin{array}{l}\text { Random sequence genera- } \\
\text { tion (selection bias) }\end{array}$ & Unclear risk & No details. \\
\hline $\begin{array}{l}\text { Allocation concealment } \\
\text { (selection bias) }\end{array}$ & Low risk & "numbered envelopes". \\
\hline $\begin{array}{l}\text { Blinding of participants } \\
\text { and personnel (perfor- } \\
\text { mance bias) }\end{array}$ & High risk & Open study. \\
All outcomes & & \\
\hline
\end{tabular}

\begin{tabular}{|c|c|c|}
\hline $\begin{array}{l}\text { Blinding of outcome as- } \\
\text { sessment (detection bias) } \\
\text { All outcomes }\end{array}$ & High risk & Open study. \\
\hline
\end{tabular}

Incomplete outcome data Unclear risk No description of withdrawals during the initial treatment period
(attrition bias)

Hospital Admission

Turner 1988

\begin{tabular}{|c|c|}
\hline Methods & $\begin{array}{l}\text { Excluded: } 26 \text { out of } 101 \text { evaluated. } \\
\text { Baseline characteristics: comparable. } \\
\text { Intention-to-treat: not stated. } \\
\text { Power calculation: not stated. }\end{array}$ \\
\hline Participants & $\begin{array}{l}\text { Setting: USA. Hospital Emergency Room. } \\
53 \text { adults with asthma } 18-75 \text { years old, } 22 \text { participants with COPD also in study but excluded from this } \\
\text { review. } \\
\text { Mean FEV }{ }_{1} \text { at presentation: spacer } 1.2 \mathrm{~L} \text { (SD } 0.1 \text { ), nebuliser } 1.1 \mathrm{~L} \text { (SD } 0.1 \text { ). } \\
\text { Inclusion criteria: onset symptoms }<30 \text { years or }<10 \text { pack years smoking. } \\
\text { Exclusion criteria: pregnancy, suspected MI or CCF, intubation required. }\end{array}$ \\
\hline Interventions & $\begin{array}{l}\text { Beta }_{2} \text {-agonist: Metaproterenol. } \\
\text { Spacer: Inspirease. } \\
\text { Dosage: } 3 \text { x } 0.65 \text { mg puffs at 2-minute intervals inhaled by } 2 \text { slow inhalations each. Total of } 3 \text { treatments } \\
\text { at } 30 \text {-minute intervals. } \\
\text { Nebuliser: Acorn II. } \\
\text { Dosage: } 15 \mathrm{mg} \text { in } 2 \mathrm{~mL} \text { saline given over } 10 \text { minutes. Total of } 3 \text { treatments at } 30 \text {-minute intervals. } \\
\text { Dosage ratio: spacer:nebuliser }=1: 8 \text {. } \\
\text { Co-interventions: oxygen and intravenous steroids given at the discretion of the emergency room } \\
\text { physician who was not involved in the study. }\end{array}$ \\
\hline
\end{tabular}

Outcomes Admission to hospital, symptom score, $\mathrm{FEV}_{1}$, oxygen saturation, heart rate, respiratory rate, administra-
tion of steroids.

Notes SDs calculated from raw data supplied by the author. Predicted Peak Flow estimated.

\section{Risk of bias}


Turner 1988 (Continued)

\section{Bias Authors' judgement Support for judgement}

Random sequence genera- Unclear risk Described as randomised; other information not available.

tion (selection bias)

Allocation concealment $\quad$ Unclear risk Information not available.
(selection bias)

(selection bias)

Blinding of participants Low risk Double-blind, double-dummy.

and personnel (perfor-

mance bias)

All outcomes

Blinding of outcome as-
sessment (detection bias) $\quad$ Low risk Double-blind, double-dummy.

All outcomes

Incomplete outcome data Unclear risk No details of dropouts reported.
(attrition bias)

(attrition bias)

Hospital Admission

Valencia 1999

\begin{tabular}{ll}
\hline Methods & $\begin{array}{l}\text { Baseline characteristics: comparable. } \\
\text { Intention-to-treat: not stated. } \\
\text { Power calculation: not stated. }\end{array}$ \\
\hline Participants & Setting: Casualty Department of Children's hospital in Columbia. 70 children with acute asthma aged \\
from $1-6$ years old, mean age 3.2 years (spacer) and 3.6 years (nebuliser). Mean oxygen saturation $92 \%$ \\
(spacer) and 91\% (nebuliser). \\
Inclusion criteria: acute asthma exacerbation. \\
Exclusion criteria: not stated.
\end{tabular}

\begin{tabular}{ll}
\hline Interventions & Beta ${ }_{2}$-agonist: Salbutamol. \\
& Spacer: Type unspecified ( $500 \mathrm{~mL}$ size). \\
& Dosage: $2 \times 100 \mathrm{mcg}$ given 3 times at 20 -minute intervals. \\
& Nebuliser: Breath Neb II. \\
& Dosage: $0.15 \mathrm{mg} / \mathrm{kg}$ diluted in $4 \mathrm{~mL}$ of saline, given 3 times at 20-minute intervals. \\
& Dosage ratio: not stated. \\
& Co-interventions: not stated. \\
\hline Outcomes & Respiratory rate, oxygen saturation, participant rating, clinical response all after 60 minutes. \\
\hline Notes & Paper states that 2 doses of $100 \mathrm{mg}$ were given via spacer but this has been assumed to be a misprint \\
& for $100 \mathrm{mcg}$. \\
\hline
\end{tabular}

\section{Risk of bias}

\begin{tabular}{lll}
\hline Bias & Authors' judgement & Support for judgement \\
\hline $\begin{array}{l}\text { Random sequence genera- } \\
\text { tion (selection bias) }\end{array}$ & Low risk & Used True-epistat to assign treatment groups. \\
\hline $\begin{array}{l}\text { Allocation concealment } \\
\text { (selection bias) }\end{array}$ & Unclear risk & No details. \\
\hline
\end{tabular}


Valencia 1999 (Continued)

Blinding of participants High risk Open study. and personnel (performance bias)

All outcomes

\begin{tabular}{lll}
\hline Blinding of outcome as- & High risk & Open study. \\
sessment (detection bias) & & \\
All outcomes &
\end{tabular}

Incomplete outcome data Unclear risk

No details of dropouts reported.

(attrition bias)

No details of dropouts reported.

Hospital Admission

\section{Vazquez 1992}

\begin{tabular}{|c|c|}
\hline Methods & $\begin{array}{l}\text { Baseline characteristics: comparable. } \\
\text { Intention to treat: not stated. } \\
\text { Power calculation: not stated. }\end{array}$ \\
\hline Participants & $\begin{array}{l}\text { Setting: Spain. Hospital Emergency Room. } \\
18 \text { children with asthma. Mean age } 9.33 \text { years (spacer), } 8.66 \text { years (nebuliser). } \\
\text { Mean FEV } 1 \text { ( } \% \text { predicted): spacer } 41.3 \% \text { (SD 16\%), nebuliser 39.6\%(SD 19\%). } \\
\text { Inclusion criteria: FEV }{ }_{1} \text { less than } 65 \% \text { predicted and no beta-agonist given in the previous } 2 \text { hours. }\end{array}$ \\
\hline Interventions & $\begin{array}{l}\text { Beta }{ }_{2} \text {-agonist: Salbutamol. } \\
\text { Spacer: Volumatic. } \\
\text { Dosage: } 5 \text { x } 100 \mathrm{mcg} \text { together into spacer followed by } 30 \text { seconds of tidal breathing. Followed by } 10 \times \\
100 \mathrm{mcg} \text { every } 20 \text { minutes until stable or } 1.5 \mathrm{mg} / \mathrm{kg} \text { maximum dose. } \\
\text { Nebuliser: Type not stated. } \\
\text { Dosage: } 500 \mathrm{mcg} \text { diluted in } 3 \mathrm{~mL} \text { driven by oxygen at } 7 \mathrm{~L} / \mathrm{min} \text {. } \\
\text { Dosage ratio: spacer:nebuliser = } 1.3: 1 \text { Total average dose by spacer } 3.2 \mathrm{mg} \text { (SD } 1 \text { ) and by nebuliser } 2.5 \\
\mathrm{mg} \text { (SD 0.7). } \\
\text { Co-interventions: not stated. }\end{array}$ \\
\hline
\end{tabular}

\begin{tabular}{ll}
\hline Outcomes & Admission to hospital, peak flow, $\mathrm{FEV}_{1}, \mathrm{FVC}$, oxygen saturation, heart rate. \\
\hline Notes & $\begin{array}{l}\text { Improvement in lung function expressed as \% maximum predicted (see footnote). } \\
\text { No significant changes in blood gases in either group. }\end{array}$ \\
\hline
\end{tabular}

\section{Risk of bias}

\begin{tabular}{lll}
\hline Bias & Authors' judgement & Support for judgement \\
\hline $\begin{array}{l}\text { Random sequence genera- } \\
\text { tion (selection bias) }\end{array}$ & Unclear risk & Information not available. \\
\hline $\begin{array}{l}\text { Allocation concealment } \\
\text { (selection bias) }\end{array}$ & Unclear risk & Informaion not available. \\
\hline $\begin{array}{l}\text { Blinding of participants } \\
\text { and personnel (perfor- } \\
\text { mance bias) }\end{array}$ & High risk & Open study. \\
$\begin{array}{l}\text { All outcomes } \\
\begin{array}{l}\text { Blinding of outcome as- } \\
\text { sessment (detection bias) }\end{array}\end{array}$ & High risk & Open study. \\
\hline
\end{tabular}


Vazquez 1992 (Continued)

All outcomes

Incomplete outcome data Unclear risk No details of dropouts reported.
(attrition bias)

Hospital Admission

Vivek 2003

\begin{tabular}{ll} 
Methods & Baseline characteristics: "comparable". \\
& Power calculation: not stated. \\
\hline Participants & Setting: South India. Emergency Room. \\
& 122 adults and children aged $10-50$ years. 54 participants allocated to nebuliser and 68 allocated to \\
& spacer. \\
& Mean PEF at presentation: $200-250 \mathrm{~L} / \mathrm{min}$. \\
& Inclusion criteria:acute exacerbation of asthma (PEF $200-250 \mathrm{~L} / \mathrm{min})$. \\
& Exclusion criteria: not stated.
\end{tabular}

\begin{tabular}{ll}
\hline Interventions & Beta 2 -agonist: Terbutaline. \\
Spacer: Astra Spacehaler $(750 \mathrm{~mL})$. \\
Dosage: 6 puffs of $0.25 \mathrm{mg}$. Treatment repeated at 5 and 30 minutes. Each puff inhaled separately. \\
Nebuliser: Aerofamily nebuliser. \\
Dosage: $5 \mathrm{mg}(0.5 \mathrm{~mL}$ respirator solution $+1.5 \mathrm{~mL}$ normal saline). Treatment repeated at 5 and $30 \mathrm{~min}$ - \\
utes. \\
Dose ratio: spacer:nebuliser $=1: 4$. \\
Duration 60 minutes.
\end{tabular}

Endpoint: Terbutaline doses were administered until:
1. PEFR increased to $250 \mathrm{l} / \mathrm{min}$, or
2. Participant becomes asymptomatic, or
3. 3 doses of terbutaline given, or
4. Side effects/clinical deterioration occurred.

Notes

Risk of bias

\begin{tabular}{lll}
\hline Bias & Authors' judgement & Support for judgement \\
\hline $\begin{array}{l}\text { Random sequence genera- } \\
\text { tion (selection bias) }\end{array}$ & Low risk & Random numbers table. \\
\hline $\begin{array}{l}\text { Allocation concealment } \\
\text { (selection bias) }\end{array}$ & Unclear risk & Information not available. \\
\hline $\begin{array}{l}\text { Blinding of participants } \\
\text { and personnel (perfor- } \\
\text { mance bias) } \\
\text { All outcomes }\end{array}$ & High risk & Open study. \\
\hline
\end{tabular}

\begin{tabular}{lll}
\hline Blinding of outcome as- & High risk & Open study. \\
sessment (detection bias) & \\
All outcomes & \\
\hline
\end{tabular}

Incomplete outcome data Unclear risk No details of withdrawals.

(attrition bias) 
Vivek 2003 (Continued)

Hospital Admission

Williams 1996

\begin{tabular}{|c|c|}
\hline Methods & $\begin{array}{l}\text { Baseline characteristics: comparable. } \\
\text { Intention-to-treat analysis: not required. }\end{array}$ \\
\hline Participants & $\begin{array}{l}\text { Denver, USA. Urban paediatric Emergency Department. } \\
60 \text { children aged } 6 \text { years or older. } \\
\text { Mean PEF at presentation } 46 \% \text { predicted. } \\
\text { Inclusion criteria: past history of asthma or current reversibility with albuterol. } \\
\text { Exclusion criteria: corticosteroid therapy in the past } 7 \text { days, chronic cardiopulmonary disease other } \\
\text { than asthma and severe presentation (depressed mental status, cyanosis, impending respiratory fail- } \\
\text { ure). }\end{array}$ \\
\hline Interventions & $\begin{array}{l}\text { Beta }{ }_{2} \text {-agonist: Salbutamol (Albuterol). } \\
\text { Spacers: Aerochamber ( } 20 \text { participants) and ACE ( } 22 \text { participants), } 4 \text { × } 90 \text { mcg actuations of salbutamol } \\
\text { given separately every } 30 \text { minutes, inhaled using tidal breathing for } 1 \text { minute each. } 3 \text { treatments given } \\
\text { at 30-minute intervals. } \\
\text { Nebuliser: PARI-JET II } 2.5 \mathrm{mg} \text { of Albuterol given every } 30 \text { minutes in } 3 \mathrm{~mL} \text { saline driven by pressurised } \\
\text { air at } 6 \mathrm{~L} \text { per minute. } 3 \text { treatments given at } 30 \text {-minute intervals. } \\
\text { Co-interventions: oxygen was given to all participants with an oxygen saturation of less than } 92 \% \text { while } \\
\text { breathing room air. All participants were given oral prednisolone at a dose of } 2 \mathrm{mg} / \mathrm{kg} \text { (maximum } 60 \\
\mathrm{mg} \text { ) within } 30 \text { minutes of enrolment. }\end{array}$ \\
\hline
\end{tabular}

\begin{tabular}{ll}
\hline Outcomes & Admission to hospital, change in \% predicted peak flow, change in \% predicted respiratory rate. \\
\hline Notes & $\begin{array}{l}\text { The results for the } 2 \text { spacers were pooled. } 4 \text { participants required additional treatment in the emer- } \\
\text { gency department with } 1 \text { - } 3 \text { further treatments with nebulised albuterol before they were discharged; } \\
\text { these were } 1 \text { from the nebuliser group and } 3 \text { from the spacer groups. }\end{array}$
\end{tabular}

\section{Risk of bias}

\begin{tabular}{lll}
\hline Bias & Authors' judgement & Support for judgement \\
\hline $\begin{array}{l}\text { Random sequence genera- } \\
\text { tion (selection bias) }\end{array}$ & Unclear risk & Information not available. \\
\hline $\begin{array}{l}\text { Allocation concealment } \\
\text { (selection bias) }\end{array}$ & Unclear risk & No details. \\
\hline $\begin{array}{l}\text { Blinding of participants } \\
\text { and personnel (perfor- } \\
\text { mance bias) } \\
\text { All outcomes }\end{array}$ & High risk & Open study. \\
\hline
\end{tabular}

\begin{tabular}{lll}
\hline $\begin{array}{l}\text { Blinding of outcome as- } \\
\text { sessment (detection bias) } \\
\text { All outcomes }\end{array}$ & Low risk & The physician investigator remained blind to the delivery system. \\
\hline $\begin{array}{l}\text { Incomplete outcome data } \\
\text { (attrition bias) } \\
\text { Hospital Admission }\end{array}$ & Low risk & All participants completed the study. \\
\hline
\end{tabular}


Yasmin 2012

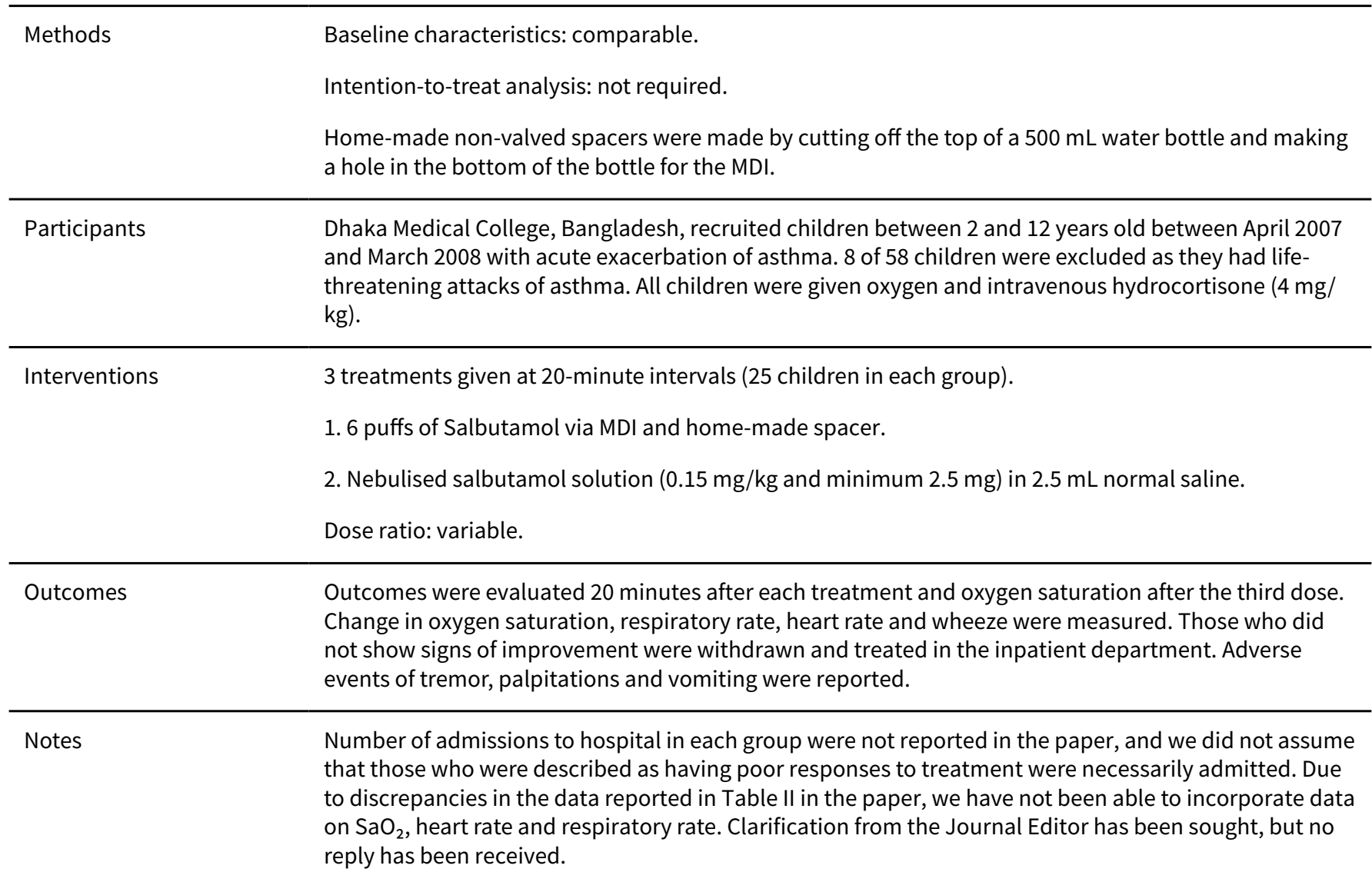

\section{Risk of bias}

\begin{tabular}{lll}
\hline Bias & Authors' judgement & Support for judgement \\
\hline $\begin{array}{l}\text { Random sequence genera- } \\
\text { tion (selection bias) }\end{array}$ & Unclear risk & Simple random number with the help of envelopes. \\
\hline $\begin{array}{l}\text { Allocation concealment } \\
\text { (selection bias) }\end{array}$ & Unclear risk & Simple random number with the help of envelopes. \\
\hline $\begin{array}{l}\text { Blinding of participants } \\
\text { and personnel (perfor- } \\
\text { mance bias) }\end{array}$ & High risk & Open study. \\
$\begin{array}{l}\text { All outcomes } \\
\begin{array}{l}\text { Blinding of outcome as- } \\
\text { sessment (detection bias) } \\
\text { All outcomes }\end{array}\end{array}$ & High risk & $\begin{array}{l}\text { No indication that assignment was concealed from those assessing the chil- } \\
\text { dren. }\end{array}$ \\
\hline $\begin{array}{l}\text { Incomplete outcome data } \\
\text { (attrition bias) } \\
\text { Hospital Admission }\end{array}$ & Unclear risk & $\begin{array}{l}\text { No description of dropouts. Eight excluded due to life threatening asthma,p- } \\
\text { neumonia, congenital heart disease or heart failure. }\end{array}$ \\
\hline
\end{tabular}

$\%$ max predicted - (post-treatment - basal)/(predicted - basal); ATS - American Thoracic Society; BTS - British Thoracic Society; CCF congestive cardiac failure; COPD - Chronic obstructive pulmonary disease; DPI - dry powder inhaler; ED - Emergency Department; ER Emergency Room; FEV 1 - Forced expiratory volume in one second; IHD - ischaemic heart disease; IV - intravenous; FVC - forced vital capacity; ITT - intention-to-treat; MDI - metered-dose inhaler; MI - myocardial infarction; NAEPP- National Asthma Education and Prevention 
Program; PEF(R) - Peak expiratory flow (rate); puff - actuation of metered-dose inhaler; $\mathrm{SaO}_{2}$ - saturated oxygen level; SD - standard deviation.

Characteristics of excluded studies [ordered by study ID]

\begin{tabular}{|c|c|}
\hline Study & Reason for exclusion \\
\hline Beasley 1985 & $\begin{array}{l}\text { Probably hospitalised participants and no response from authors to request for further informa- } \\
\text { tion. }\end{array}$ \\
\hline Benton 1989 & Not randomised. \\
\hline Berenberg 1985 & $\begin{array}{l}\text { Mixed population of participants, not possible to separate data from asthmatics and no response } \\
\text { from authors. }\end{array}$ \\
\hline Campbell 1995 & No randomisation. \\
\hline Deerojanawong 2005 & Mean age of children was under 2 years. \\
\hline Fayaz 2009 & Not a randomised trial. \\
\hline Fuglsang 1986 & Cross-over design inappropriate for acute asthma. \\
\hline Hart 2009 & Preliminary study in 8 adults who were not clearly suffering from acute asthma \\
\hline Hodder 1988 & No outcomes presented in this abstract in a form that could be used. No response from author. \\
\hline Jasper 1987 & $\begin{array}{l}\text { Mixed population of participants, not possible to separate data from asthmatics and no response } \\
\text { from authors. }\end{array}$ \\
\hline Kaashmiri 2010 & Study in infants under 2 years of age. \\
\hline Levitt 1995 & $\begin{array}{l}\text { Mixed population of COPD and asthma; no separate data given for asthmatic participants. No re- } \\
\text { sponse from author. }\end{array}$ \\
\hline Madsen 1982 & No useable data and no response from authors. \\
\hline Maguire 1991 & Probably hospitalised patients, no response from authors to request for clarification. \\
\hline Mandelberg 1997 & $\begin{array}{l}\text { Mixed population of COPD and asthma; no separate data given for asthmatic patients. No response } \\
\text { from author. }\end{array}$ \\
\hline Mandelberg 2000 & Infants and young children with a median age of 16 months. \\
\hline Morgan 1982 & No standard deviation published in paper and no reply from authors. No useable data. \\
\hline Newman 2002 & Non-randomised (before-and-after study). \\
\hline Rubilar 2000 & Study in infants of 1 - 24 months. \\
\hline Shaikh 2001 & Not acute asthma. \\
\hline Shim 1984 & Not acute asthma. \\
\hline Summer 1989 & Different beta ${ }_{2}$-agonists used. \\
\hline Tarala 1980 & No holding chamber used. \\
\hline
\end{tabular}




\begin{tabular}{ll}
\hline Study & Reason for exclusion \\
\hline Vilarinho 2003 & Not acute asthma. Children using bronchodilators or corticosteroids were excluded. \\
\hline Wildhaber 1999 & Not acute asthma. \\
\hline
\end{tabular}

\section{DATA AND ANALYSES}

\section{Comparison 1. Spacer (chamber) versus nebuliser (multiple-treatment studies)}

\begin{tabular}{|c|c|c|c|c|}
\hline Outcome or subgroup title & $\begin{array}{l}\text { No. of } \\
\text { studies }\end{array}$ & $\begin{array}{l}\text { No. of } \\
\text { partici- } \\
\text { pants }\end{array}$ & Statistical method & Effect size \\
\hline 1 Hospital admission & 18 & & Risk Ratio (M-H, Fixed, 95\% Cl) & Subtotals only \\
\hline 1.1 Adults & 9 & 582 & Risk Ratio (M-H, Fixed, 95\% Cl) & $0.94[0.61,1.43]$ \\
\hline 1.2 Children & 9 & 757 & Risk Ratio (M-H, Fixed, 95\% Cl) & $0.71[0.47,1.08]$ \\
\hline $\begin{array}{l}2 \text { Hospital admission or poor re- } \\
\text { sponse to treatment }\end{array}$ & 21 & & Risk Ratio (M-H, Fixed, 95\% Cl) & Subtotals only \\
\hline 2.1 Adults & 9 & 582 & Risk Ratio (M-H, Fixed, 95\% Cl) & $0.94[0.61,1.43]$ \\
\hline 2.2 Children & 12 & 937 & Risk Ratio (M-H, Fixed, 95\% Cl) & $1.00[0.75,1.33]$ \\
\hline $\begin{array}{l}3 \text { Duration in emergency depart- } \\
\text { ment (minutes). }\end{array}$ & 5 & & $\begin{array}{l}\text { Mean Difference (IV, Random, 95\% } \\
\mathrm{CI})\end{array}$ & Subtotals only \\
\hline 3.1 Adults & 2 & 132 & $\begin{array}{l}\text { Mean Difference (IV, Random, 95\% } \\
\mathrm{CI})\end{array}$ & $1.75[-23.45,26.95]$ \\
\hline 3.2 Children & 3 & 396 & $\begin{array}{l}\text { Mean Difference (IV, Random, 95\% } \\
\mathrm{CI})\end{array}$ & $-33.48[-43.32,-23.65]$ \\
\hline 4 Final rise in $\mathrm{FEV}_{1}$ (\% predicted) & 8 & & Mean Difference (IV, Fixed, 95\% CI) & Subtotals only \\
\hline 4.1 Adults & 6 & 307 & Mean Difference (IV, Fixed, 95\% CI) & $0.96[-2.54,4.46]$ \\
\hline 4.2 Children & 2 & 48 & Mean Difference (IV, Fixed, 95\% CI) & $0.92[-4.96,6.79]$ \\
\hline $\begin{array}{l}530 \text { minute rise in } \mathrm{FEV}_{1} \text { (\% predict- } \\
\text { ed) }\end{array}$ & 3 & & Mean Difference (IV, Fixed, 95\% CI) & Subtotals only \\
\hline 5.1 Adults & 3 & 200 & Mean Difference (IV, Fixed, 95\% CI) & $-0.20[-3.18,2.78]$ \\
\hline $\begin{array}{l}6 \text { Severe asthmatics final rise in } \mathrm{FEV}_{1} \\
\text { (\% predicted) }\end{array}$ & 4 & & Mean Difference (IV, Fixed, 95\% CI) & Subtotals only \\
\hline 6.1 Adults & 4 & 94 & Mean Difference (IV, Fixed, 95\% Cl) & $1.60[-4.49,7.69]$ \\
\hline
\end{tabular}




\begin{tabular}{|c|c|c|c|c|}
\hline Outcome or subgroup title & $\begin{array}{l}\text { No. of } \\
\text { studies }\end{array}$ & $\begin{array}{l}\text { No. of } \\
\text { partici- } \\
\text { pants }\end{array}$ & Statistical method & Effect size \\
\hline $\begin{array}{l}7 \text { Final rise in peak flow (\% predict- } \\
\text { ed) }\end{array}$ & 6 & & Mean Difference (IV, Fixed, 95\% CI) & Subtotals only \\
\hline 7.1 Adults & 3 & 139 & Mean Difference (IV, Fixed, 95\% CI) & $-0.49[-4.60,3.63]$ \\
\hline 7.2 Children & 3 & 166 & Mean Difference (IV, Fixed, 95\% CI) & $-2.99[-8.88,2.91]$ \\
\hline $\begin{array}{l}830 \text { minute rise in peak flow (\% pre- } \\
\text { dicted) }\end{array}$ & 2 & & Mean Difference (IV, Fixed, 95\% CI) & Subtotals only \\
\hline 8.1 Adults & 2 & 147 & Mean Difference (IV, Fixed, 95\% CI) & $0.92[-2.68,4.51]$ \\
\hline 9 Rise in pulse rate (\% baseline) & 16 & & $\begin{array}{l}\text { Mean Difference (IV, Random, 95\% } \\
\mathrm{Cl})\end{array}$ & Subtotals only \\
\hline 9.1 Adults & 7 & 376 & $\begin{array}{l}\text { Mean Difference (IV, Random, 95\% } \\
\mathrm{CI})\end{array}$ & $-1.23[-4.06,1.60]$ \\
\hline 9.2 Children & 9 & 670 & $\begin{array}{l}\text { Mean Difference (IV, Random, 95\% } \\
\mathrm{CI})\end{array}$ & $-5.41[-8.34,-2.48]$ \\
\hline $\begin{array}{l}10 \% \text { Oxygen saturation (change } \\
\text { from baseline) }\end{array}$ & 6 & & Mean Difference (IV, Fixed, 95\% CI) & Subtotals only \\
\hline 10.1 Adults & 0 & 0 & Mean Difference (IV, Fixed, 95\% CI) & $0.0[0.0,0.0]$ \\
\hline 10.2 Children & 6 & 476 & Mean Difference (IV, Fixed, 95\% CI) & $-0.19[-0.61,0.24]$ \\
\hline $\begin{array}{l}11 \text { Number of participants develop- } \\
\text { ing tremor }\end{array}$ & 8 & & Risk Ratio (IV, Random, 95\% CI) & Subtotals only \\
\hline 11.1 Adults & 4 & 234 & Risk Ratio (IV, Random, 95\% Cl) & $0.82[0.28,2.37]$ \\
\hline 11.2 Children & 4 & 254 & Risk Ratio (IV, Random, 95\% CI) & $0.64[0.44,0.95]$ \\
\hline $\begin{array}{l}12 \text { Number of participants given } \\
\text { steroids }\end{array}$ & 4 & & Risk Ratio (M-H, Random, 95\% Cl) & Subtotals only \\
\hline 12.1 Adults & 2 & 88 & Risk Ratio (M-H, Random, 95\% Cl) & $0.71[0.08,6.02]$ \\
\hline 12.2 Children & 2 & 297 & Risk Ratio (M-H, Random, 95\% Cl) & $1.12[0.95,1.32]$ \\
\hline $\begin{array}{l}13 \text { Rise in respiratory rate (breaths } \\
\text { per minute) }\end{array}$ & 13 & & $\begin{array}{l}\text { Mean Difference (IV, Random, 95\% } \\
\text { CI) }\end{array}$ & Subtotals only \\
\hline 13.1 Adults & 5 & 257 & $\begin{array}{l}\text { Mean Difference (IV, Random, 95\% } \\
\text { CI) }\end{array}$ & $0.28[-2.29,2.84]$ \\
\hline 13.2 Children & 8 & 686 & $\begin{array}{l}\text { Mean Difference (IV, Random, 95\% } \\
\text { CI) }\end{array}$ & $-0.94[-2.84,0.97]$ \\
\hline
\end{tabular}


Analysis 1.1. Comparison 1 Spacer (chamber) versus nebuliser (multiple-treatment studies), Outcome 1 Hospital admission.

\begin{tabular}{|c|c|c|c|c|c|}
\hline Study or subgroup & $\begin{array}{c}\text { Holding } \\
\text { Chamber } \\
n / N\end{array}$ & $\begin{array}{c}\text { Nebuliser } \\
n / \mathbf{N} \\
\end{array}$ & $\begin{array}{c}\text { Risk Ratio } \\
\text { M-H, Fixed, 95\% Cl }\end{array}$ & Weight & $\begin{array}{c}\text { Risk Ratio } \\
\text { M-H, Fixed, } 95 \% \mathrm{Cl}\end{array}$ \\
\hline \multicolumn{6}{|l|}{ 1.1.1 Adults } \\
\hline Colacone 1993 & $1 / 40$ & $0 / 40$ & & $1.52 \%$ & $3[0.13,71.51]$ \\
\hline Dhuper 2008 & $1 / 29$ & $2 / 29$ & & $6.09 \%$ & $0.5[0.05,5.21]$ \\
\hline Idris 1993 & $1 / 15$ & $1 / 20$ & . & $2.61 \%$ & $1.33[0.09,19.64]$ \\
\hline Rao 2002 & $0 / 25$ & $1 / 25$ & & $4.57 \%$ & $0.33[0.01,7.81]$ \\
\hline Rodrigo 1993 & $5 / 49$ & $4 / 48$ & 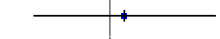 & $12.3 \%$ & $1.22[0.35,4.29]$ \\
\hline Rodriguez 1999 & $14 / 36$ & $17 / 33$ & - & $54.01 \%$ & $0.75[0.45,1.28]$ \\
\hline Turner 1988 & $4 / 27$ & $5 / 26$ & & $15.51 \%$ & $0.77[0.23,2.56]$ \\
\hline Vivek 2003 & $5 / 68$ & $1 / 54$ & & $3.39 \%$ & $3.97[0.48,32.98]$ \\
\hline Subtotal $(95 \% \mathrm{Cl})$ & 298 & 284 & & $100 \%$ & $0.94[0.61,1.43]$ \\
\hline \multicolumn{6}{|c|}{ Heterogeneity: $\mathrm{Tau}^{2}=0 ; \mathrm{Chi}^{2}=3.99, \mathrm{df}=7(\mathrm{P}=0.78) ; \mathrm{I}^{2}=0 \%$} \\
\hline \multicolumn{6}{|c|}{ Test for overall effect: $Z=0.29(P=0.77)$} \\
\hline \multicolumn{6}{|l|}{ 1.1.2 Children } \\
\hline Chong-Neto 2005 & $0 / 20$ & $0 / 10$ & & & Not estimable \\
\hline Chou 1995 & $4 / 71$ & $5 / 81$ & & $11.36 \%$ & $0.91[0.25,3.27]$ \\
\hline Direkwatanachai 2008 & $1 / 68$ & $2 / 77$ & & $4.56 \%$ & $0.57[0.05,6.11]$ \\
\hline Jamalvi 2006 & $4 / 84$ & $7 / 66$ & - & $19.07 \%$ & $0.45[0.14,1.47]$ \\
\hline Leversha 2000 & $10 / 30$ & $18 / 30$ & & $43.79 \%$ & $0.56[0.31,1]$ \\
\hline Ploin 2000 & $3 / 31$ & $3 / 32$ & & $7.18 \%$ & $1.03[0.23,4.73]$ \\
\hline Sannier 2007 & $6 / 39$ & $3 / 40$ & & $7.21 \%$ & $2.05[0.55,7.63]$ \\
\hline Vazquez 1992 & $0 / 9$ & $0 / 9$ & & & Not estimable \\
\hline Williams 1996 & $2 / 42$ & $2 / 18$ & $\rightarrow$ & $6.81 \%$ & $0.43[0.07,2.81]$ \\
\hline \multicolumn{6}{|c|}{ Heterogeneity: $\mathrm{Tau}^{2}=0 ; \mathrm{Chi}^{2}=4.45, \mathrm{df}=6(\mathrm{P}=0.62) ; \mathrm{I}^{2}=0 \%$} \\
\hline \multicolumn{6}{|c|}{ Test for overall effect: $Z=1.61(P=0.11)$} \\
\hline Test for subgroup differ & $d f=1(P=0.36)$ & & & & \\
\hline
\end{tabular}

Analysis 1.2. Comparison 1 Spacer (chamber) versus nebuliser (multipletreatment studies), Outcome 2 Hospital admission or poor response to treatment.

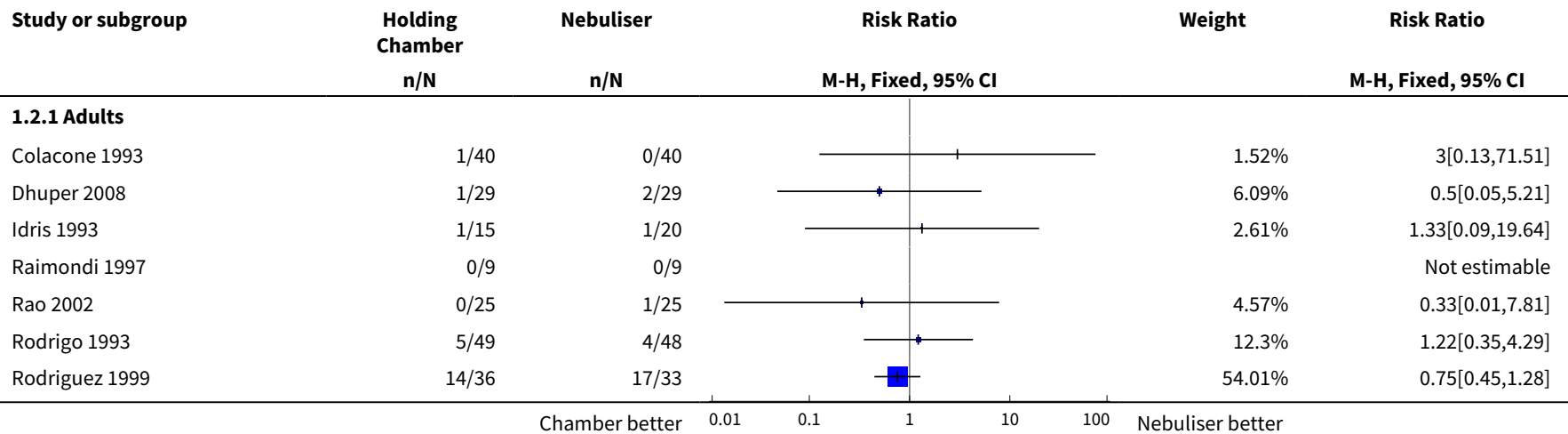




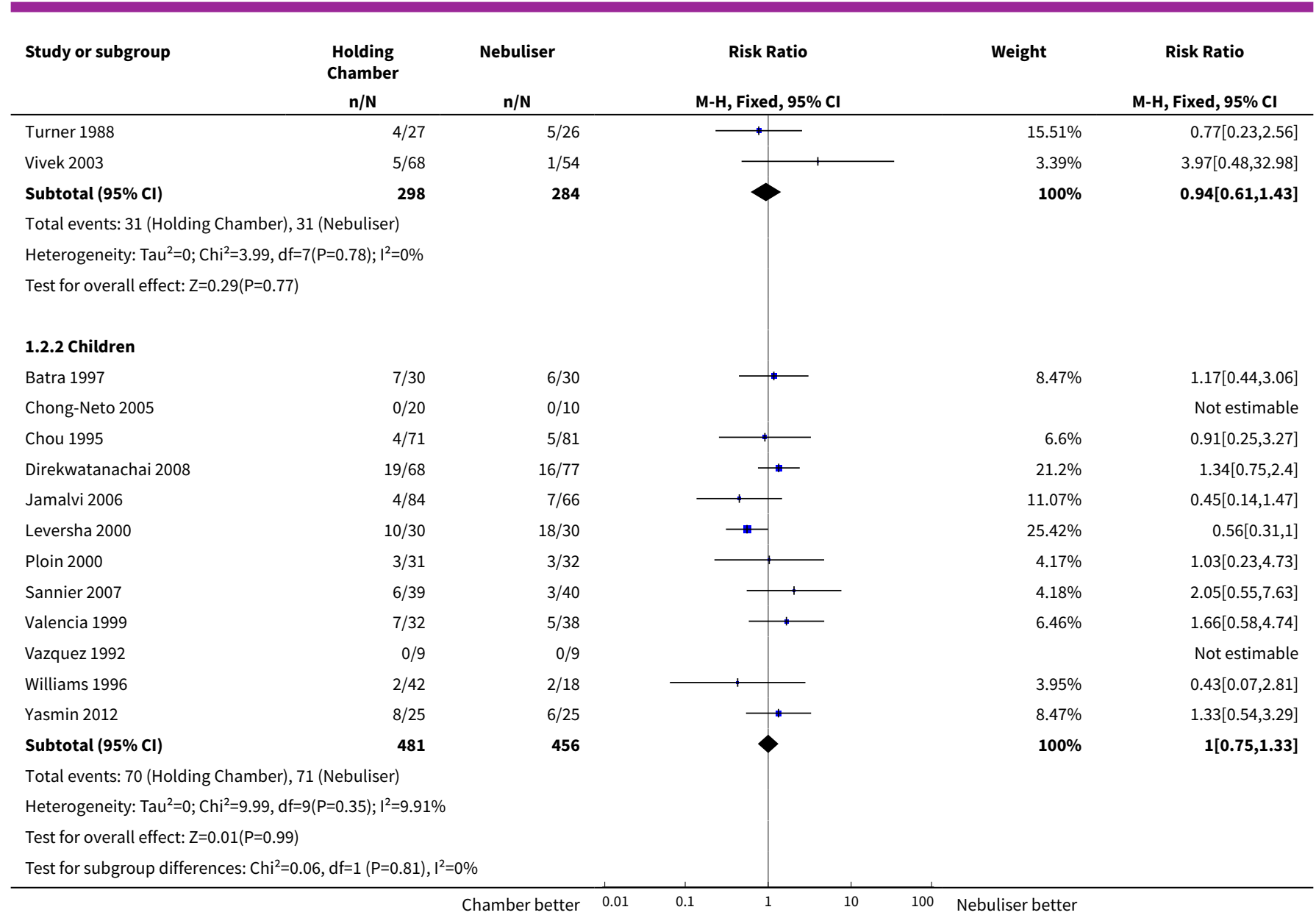

Analysis 1.3. Comparison 1 Spacer (chamber) versus nebuliser (multipletreatment studies), Outcome 3 Duration in emergency department (minutes)..

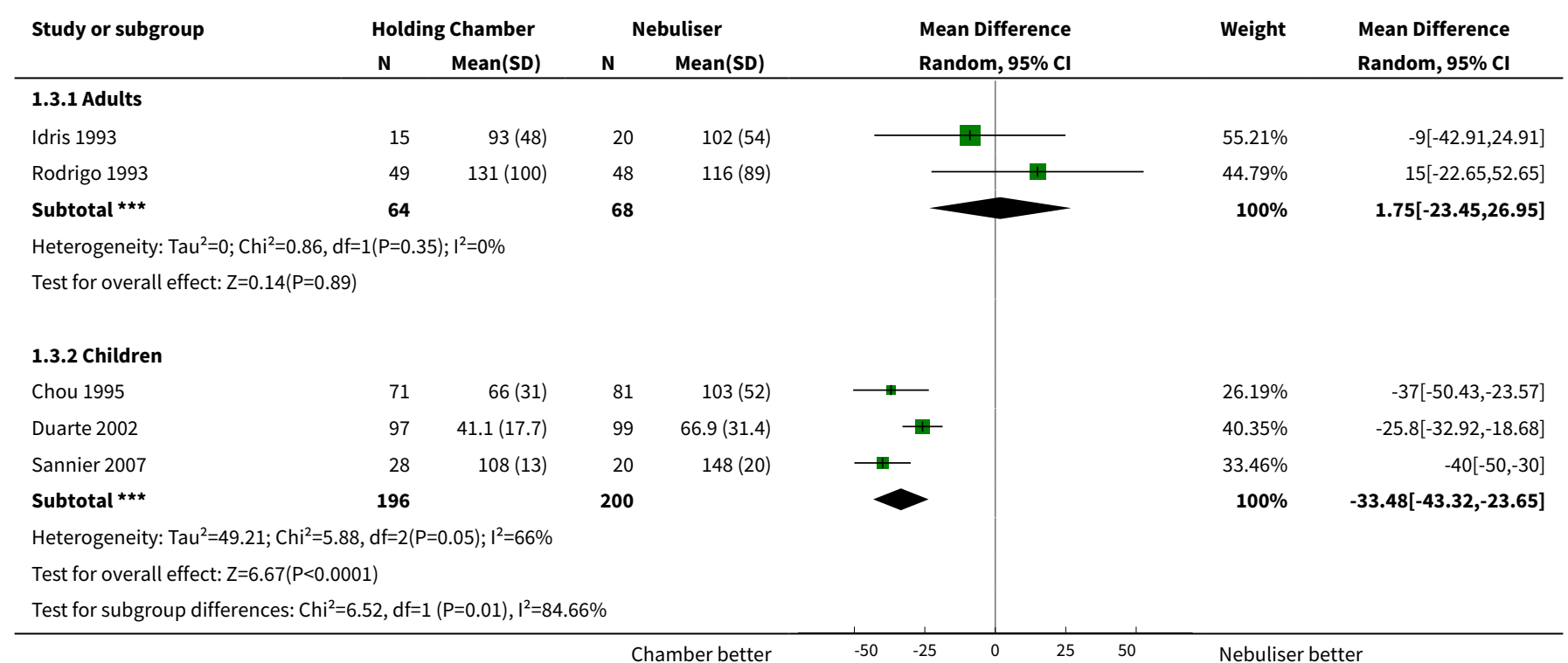


Analysis 1.4. Comparison 1 Spacer (chamber) versus nebuliser (multipletreatment studies), Outcome 4 Final rise in $\mathrm{FEV}_{1}$ (\% predicted).

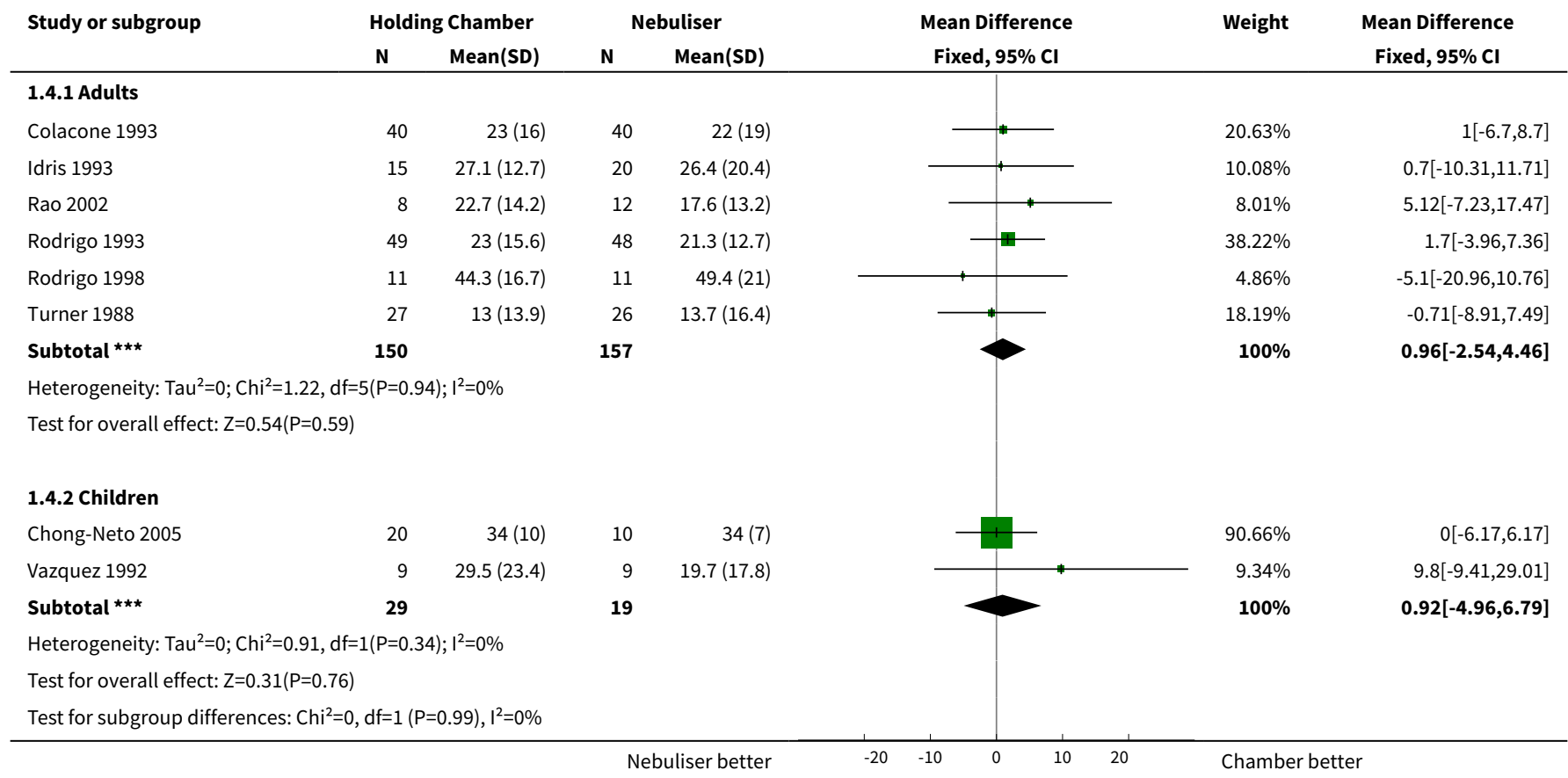

Analysis 1.5. Comparison 1 Spacer (chamber) versus nebuliser (multipletreatment studies), Outcome $\mathbf{5} 30$ minute rise in $\mathrm{FEV}_{\mathbf{1}}$ (\% predicted).

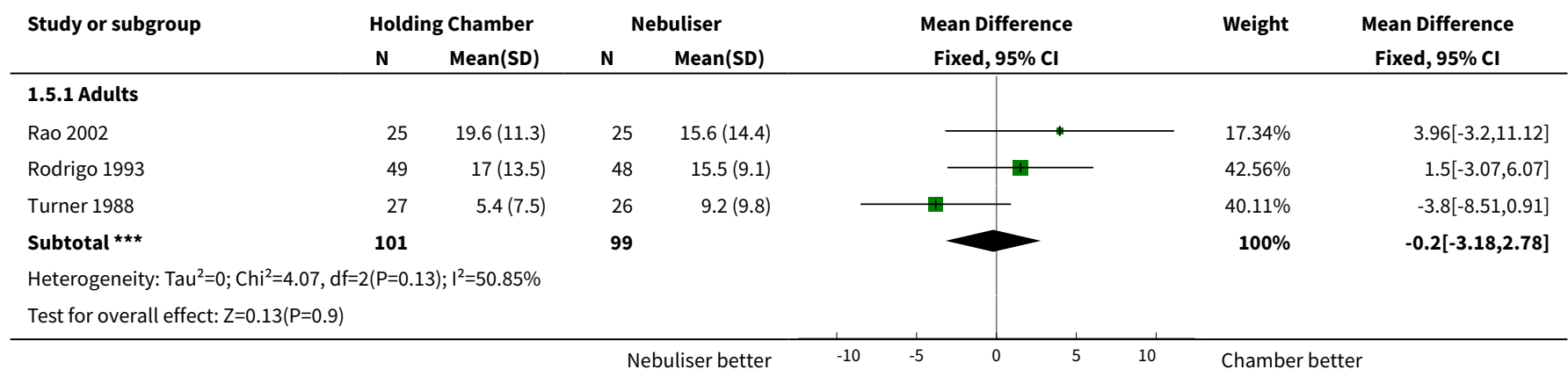

Analysis 1.6. Comparison 1 Spacer (chamber) versus nebuliser (multipletreatment studies), Outcome 6 Severe asthmatics final rise in FEV $_{1}$ (\% predicted).

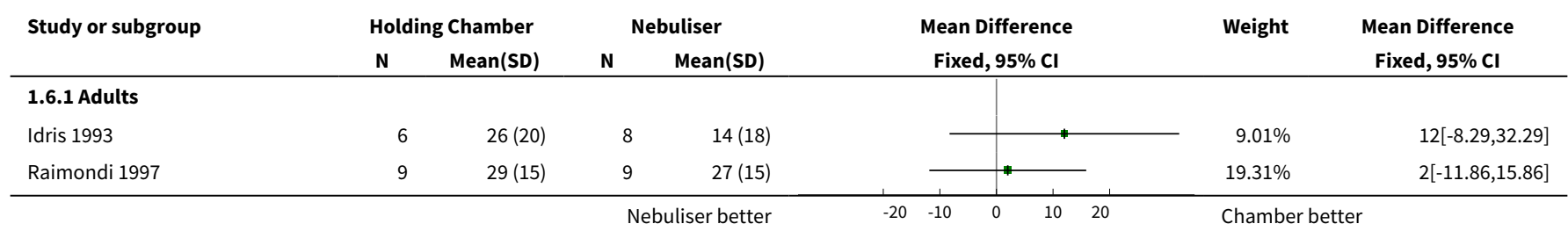




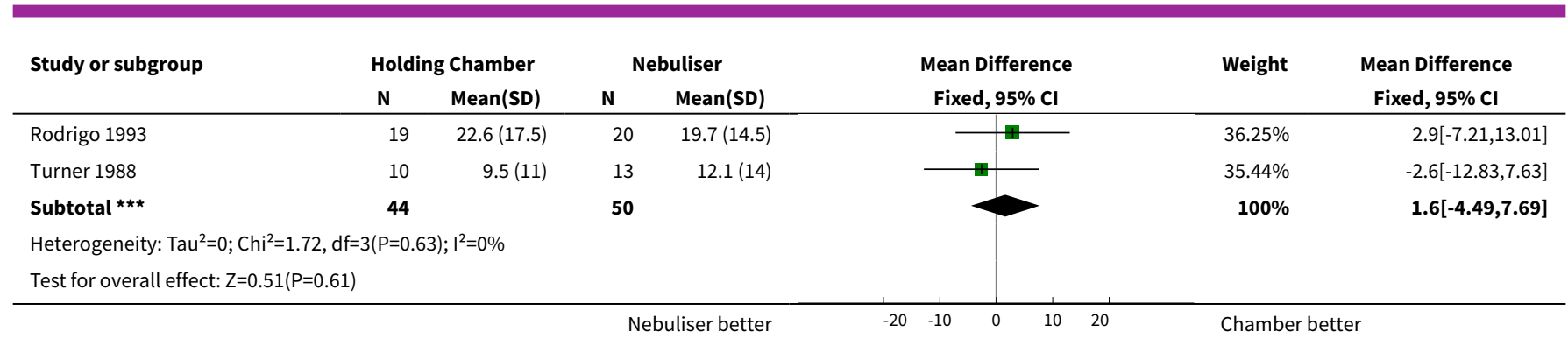

Analysis 1.7. Comparison 1 Spacer (chamber) versus nebuliser (multipletreatment studies), Outcome 7 Final rise in peak flow (\% predicted).

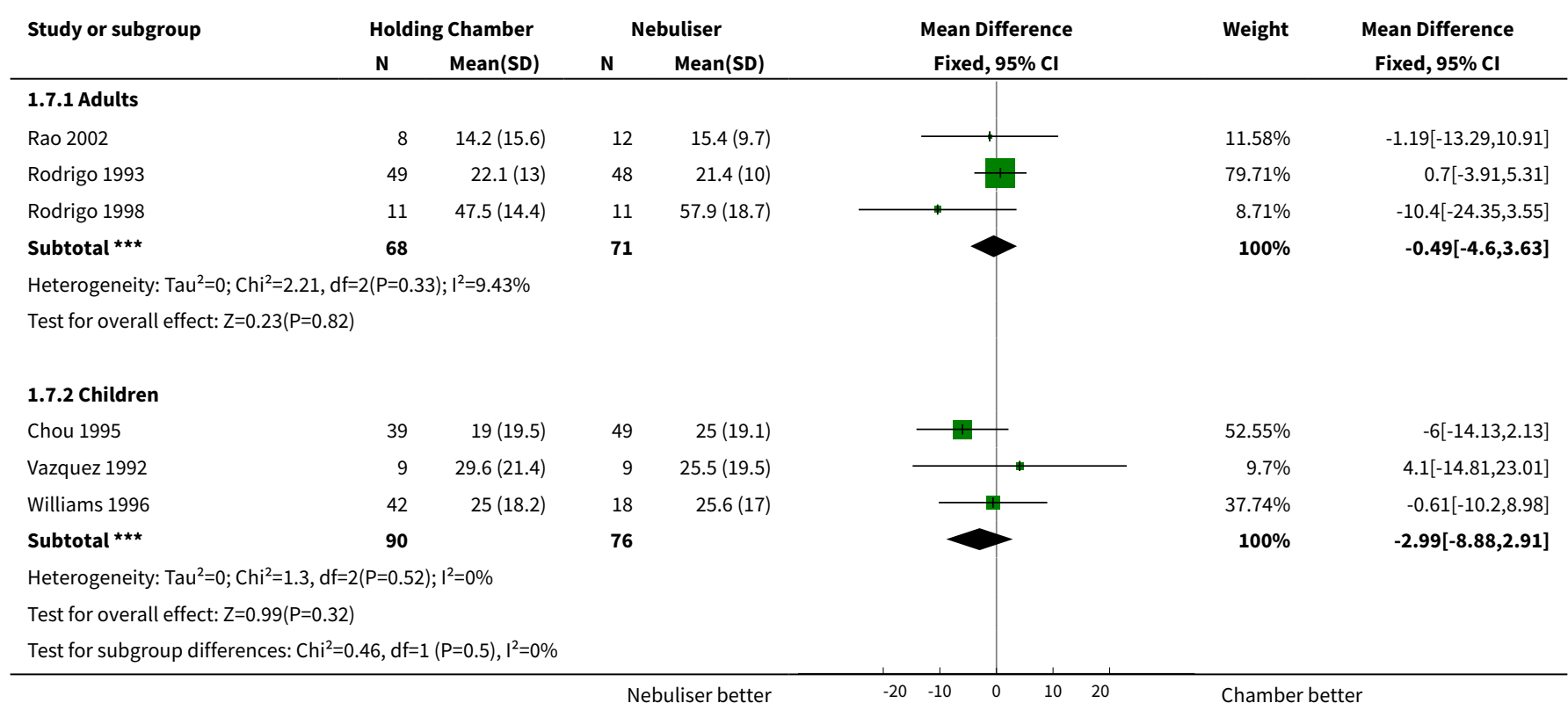

Analysis 1.8. Comparison $1 \mathrm{Spacer}$ (chamber) versus nebuliser (multipletreatment studies), Outcome 830 minute rise in peak flow (\% predicted).

\begin{tabular}{|c|c|c|c|c|c|c|c|}
\hline \multirow[t]{2}{*}{ Study or subgroup } & \multicolumn{2}{|c|}{ Holding Chamber } & \multicolumn{2}{|c|}{ Nebuliser } & \multirow{2}{*}{$\begin{array}{c}\text { Mean Difference } \\
\text { Fixed, } 95 \% \mathrm{Cl}\end{array}$} & \multirow[t]{2}{*}{ Weight } & \multirow{2}{*}{$\begin{array}{c}\text { Mean Difference } \\
\text { Fixed, } 95 \% \mathrm{Cl}\end{array}$} \\
\hline & $\mathbf{N}$ & $\operatorname{Mean}(S D)$ & $\mathbf{N}$ & $\operatorname{Mean}(S D)$ & & & \\
\hline \multicolumn{8}{|l|}{ 1.8.1 Adults } \\
\hline Rao 2002 & 25 & $14.2(13.9)$ & 25 & $12.5(14.2)$ & & $21.17 \%$ & $1.72[-6.09,9.53]$ \\
\hline Rodrigo 1993 & 49 & $15.4(11.4)$ & 48 & $14.7(8.8)$ & & $78.83 \%$ & $0.7[-3.35,4.75]$ \\
\hline Subtotal $\star \star \star$ & 74 & & 73 & & & $100 \%$ & $0.92[-2.68,4.51]$ \\
\hline \multicolumn{8}{|c|}{ Heterogeneity: $\mathrm{Tau}^{2}=0 ; \mathrm{Chi}^{2}=0.05, \mathrm{df}=1(\mathrm{P}=0.82) ; \mathrm{I}^{2}=0 \%$} \\
\hline
\end{tabular}


Analysis 1.9. Comparison 1 Spacer (chamber) versus nebuliser (multiple-treatment studies), Outcome 9 Rise in pulse rate (\% baseline).

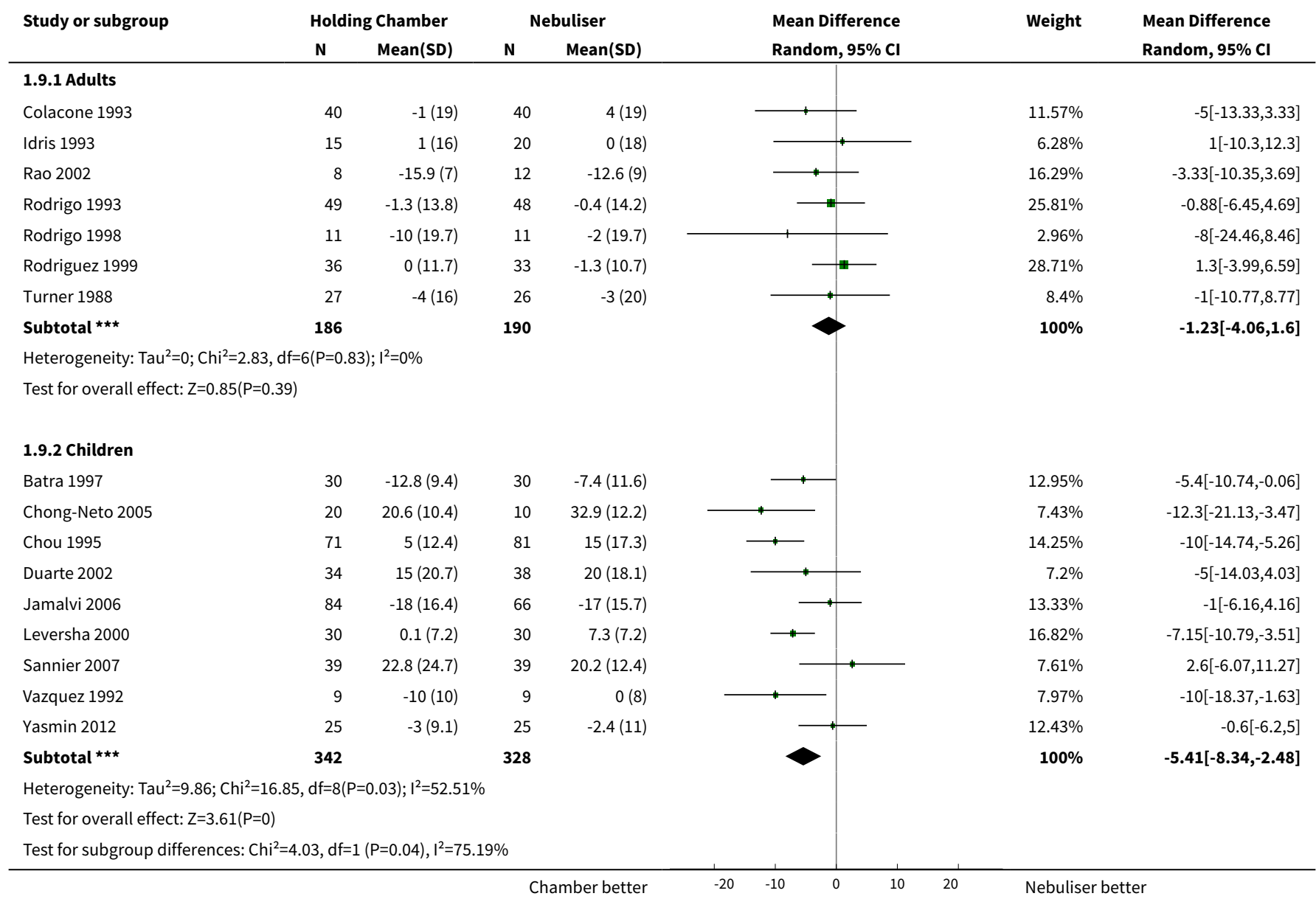

Analysis 1.10. Comparison 1 Spacer (chamber) versus nebuliser (multipletreatment studies), Outcome $10 \%$ Oxygen saturation (change from baseline).

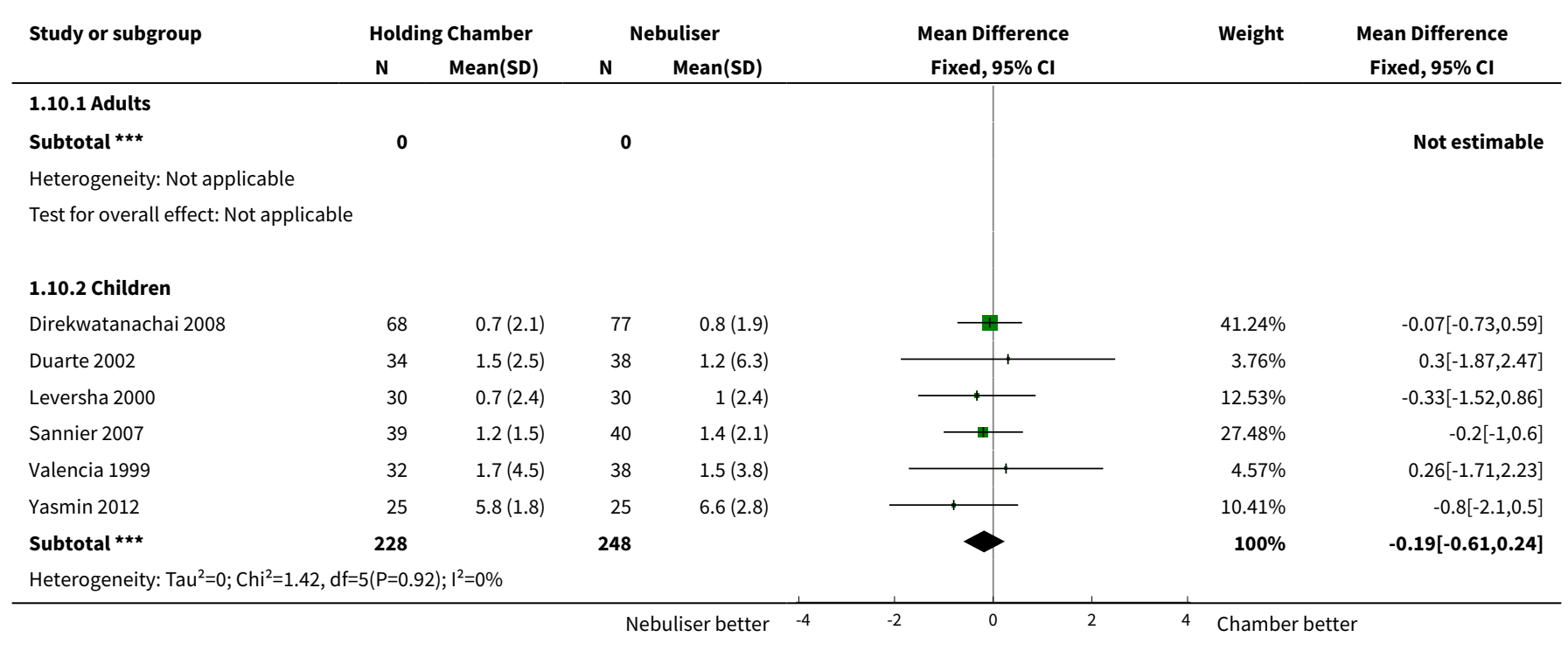




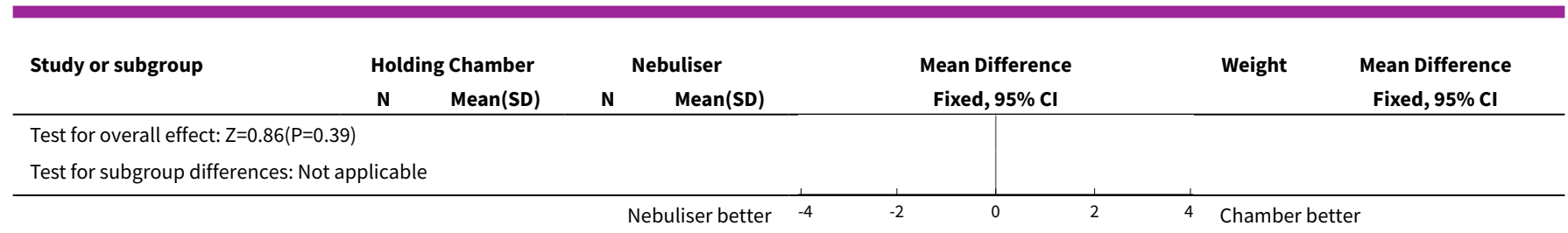

Analysis 1.11. Comparison 1 Spacer (chamber) versus nebuliser (multipletreatment studies), Outcome 11 Number of participants developing tremor.

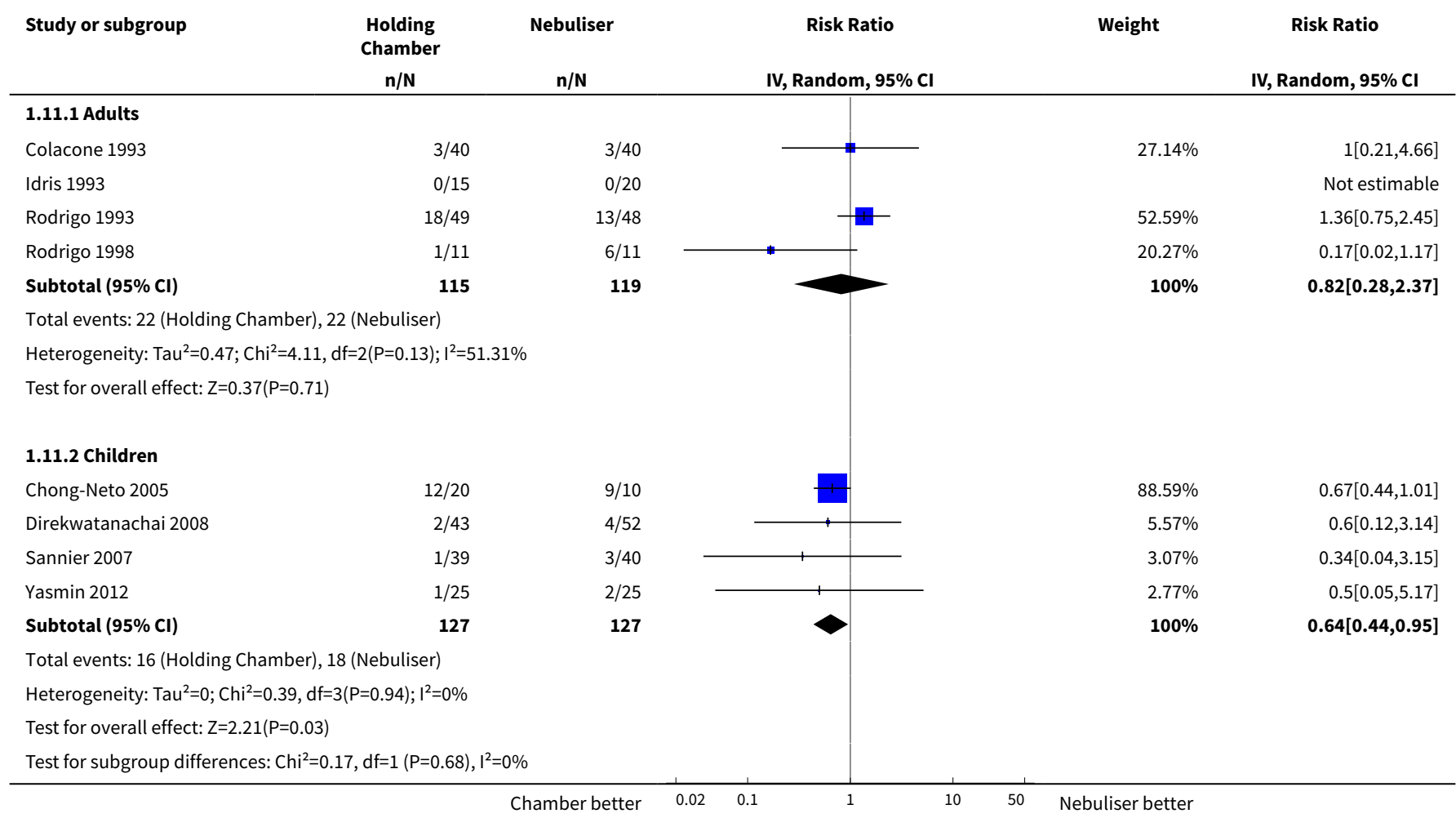

Analysis 1.12. Comparison 1 Spacer (chamber) versus nebuliser (multiple-
treatment studies), Outcome 12 Number of participants given steroids.

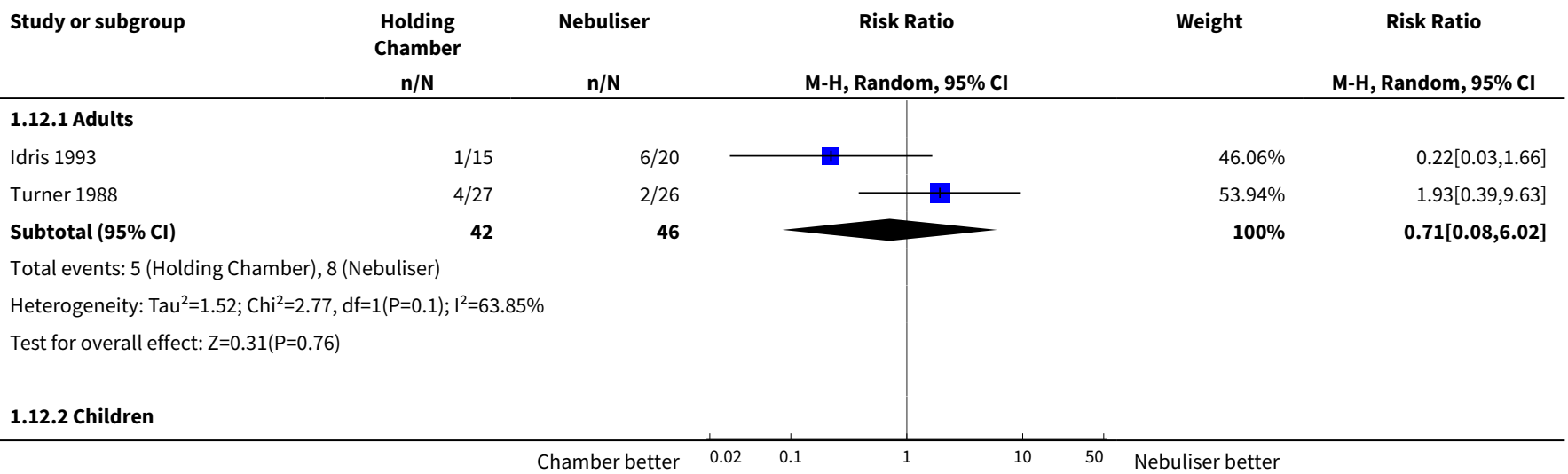




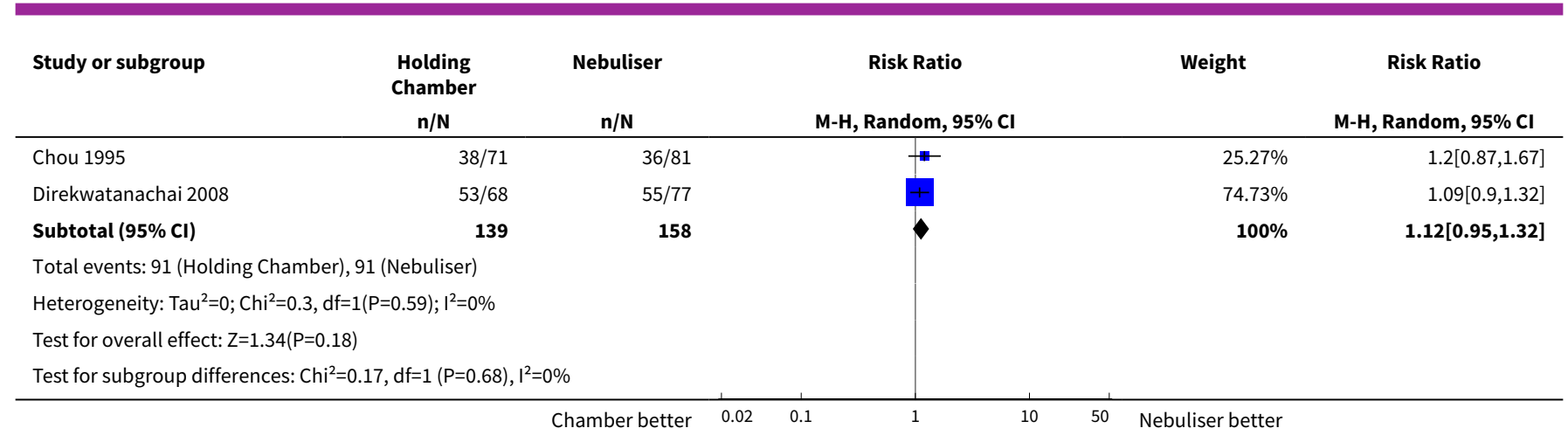

Analysis 1.13. Comparison 1 Spacer (chamber) versus nebuliser (multipletreatment studies), Outcome 13 Rise in respiratory rate (breaths per minute).

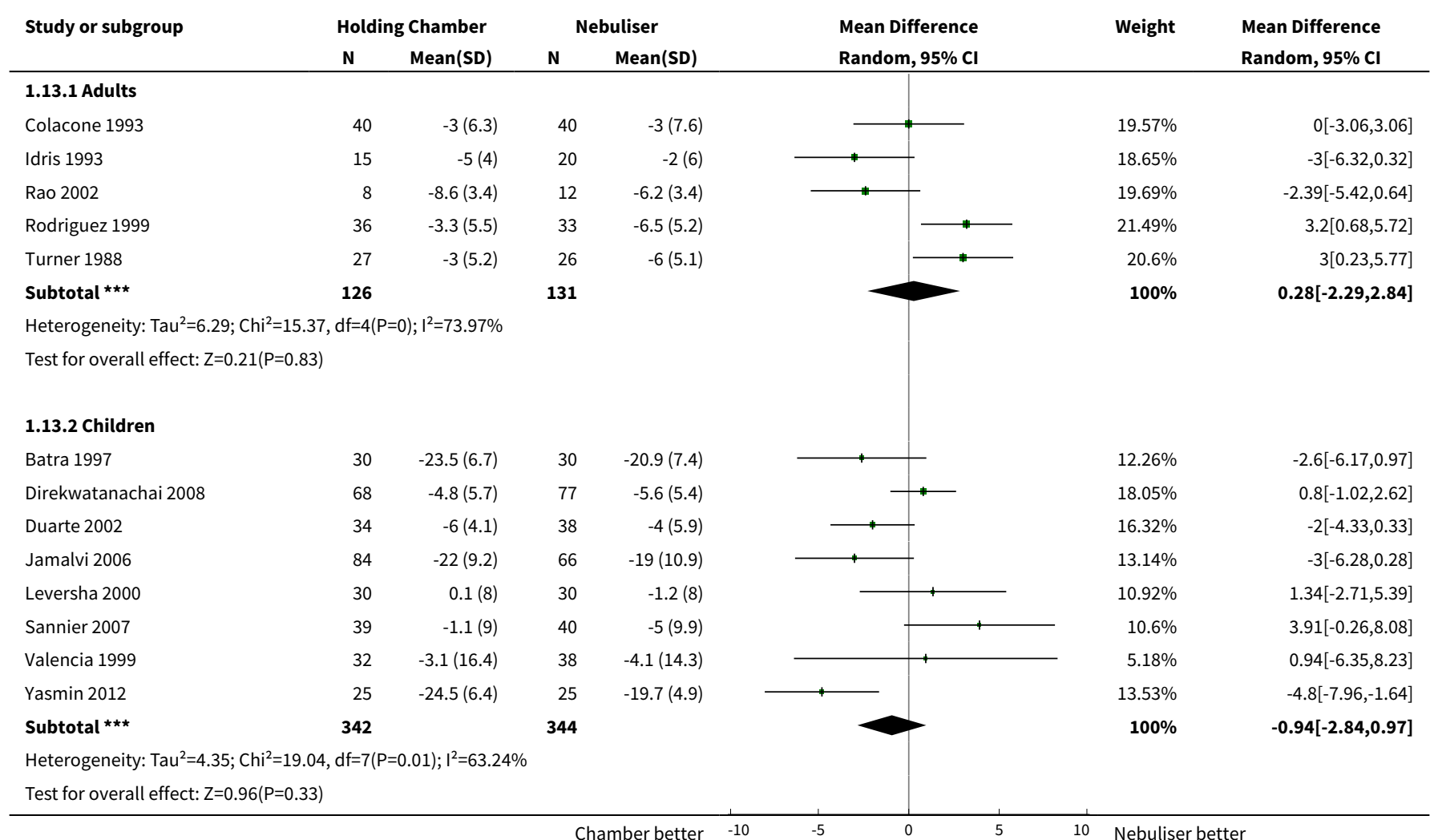

\section{Comparison 2. Spacer (chamber) versus nebuliser (single-treatment studies)}

\begin{tabular}{lllll}
\hline Outcome or subgroup title & $\begin{array}{l}\text { No. of } \\
\text { studies }\end{array}$ & $\begin{array}{l}\text { No. of } \\
\text { partici- } \\
\text { pants }\end{array}$ & Statistical method & Effect size \\
\hline 1 Hospital admission & 5 & & Risk Ratio (M-H, Fixed, $95 \% \mathrm{Cl})$ & Totals not selected \\
\hline 1.1 Adults & 1 & Risk Ratio (M-H, Fixed, $95 \% \mathrm{Cl})$ & $0.0[0.0,0.0]$ \\
\hline
\end{tabular}




\begin{tabular}{|c|c|c|c|c|}
\hline Outcome or subgroup title & $\begin{array}{l}\text { No. of } \\
\text { studies }\end{array}$ & $\begin{array}{l}\text { No. of } \\
\text { partici- } \\
\text { pants }\end{array}$ & Statistical method & Effect size \\
\hline 1.2 Children & 4 & & Risk Ratio (M-H, Fixed, 95\% Cl) & $0.0[0.0,0.0]$ \\
\hline 2 Final peak flow (\% predicted) & 1 & & Mean Difference (IV, Fixed, 95\% CI) & Totals not selected \\
\hline 2.1 Adults & 0 & & Mean Difference (IV, Fixed, 95\% CI) & $0.0[0.0,0.0]$ \\
\hline 2.2 Children & 1 & & Mean Difference (IV, Fixed, 95\% CI) & $0.0[0.0,0.0]$ \\
\hline 330 minute rise in $\mathrm{FEV}_{1}$ (\% predicted) & 2 & & Mean Difference (IV, Fixed, 95\% Cl) & Totals not selected \\
\hline 3.1 Adults & 1 & & Mean Difference (IV, Fixed, 95\% CI) & $0.0[0.0,0.0]$ \\
\hline 3.2 Children & 1 & & Mean Difference (IV, Fixed, 95\% CI) & $0.0[0.0,0.0]$ \\
\hline 415 minute rise in $\mathrm{FEV}_{1}$ (\% predicted) & 1 & & Mean Difference (IV, Fixed, 95\% CI) & Totals not selected \\
\hline 4.1 Children & 1 & & Mean Difference (IV, Fixed, 95\% CI) & $0.0[0.0,0.0]$ \\
\hline $\begin{array}{l}530 \text { minute rise in peak flow (\% pre- } \\
\text { dicted) }\end{array}$ & 3 & & Mean Difference (IV, Fixed, 95\% CI) & Totals not selected \\
\hline 5.1 Adults & 1 & & Mean Difference (IV, Fixed, 95\% CI) & $0.0[0.0,0.0]$ \\
\hline 5.2 Children & 2 & & Mean Difference (IV, Fixed, 95\% CI) & $0.0[0.0,0.0]$ \\
\hline $\begin{array}{l}615 \text { minute rise in peak flow (\% pre- } \\
\text { dicted) }\end{array}$ & 1 & & Mean Difference (IV, Fixed, 95\% CI) & Totals not selected \\
\hline 6.1 Children & 1 & & Mean Difference (IV, Fixed, 95\% CI) & $0.0[0.0,0.0]$ \\
\hline 7 Rise in pulse rate (\% baseline) & 3 & & Mean Difference (IV, Fixed, 95\% CI) & Totals not selected \\
\hline 7.1 Adults & 1 & & Mean Difference (IV, Fixed, 95\% CI) & $0.0[0.0,0.0]$ \\
\hline 7.2 Children & 2 & & Mean Difference (IV, Fixed, 95\% CI) & $0.0[0.0,0.0]$ \\
\hline $\begin{array}{l}8 \text { Number of participants developing } \\
\text { tremor }\end{array}$ & 1 & & Risk Ratio (M-H, Fixed, 95\% Cl) & Totals not selected \\
\hline 8.1 Children & 1 & & Risk Ratio (M-H, Fixed, 95\% Cl) & $0.0[0.0,0.0]$ \\
\hline $\begin{array}{l}9 \text { Number of participants with deteri- } \\
\text { oration in blood gases }\end{array}$ & 2 & & Risk Ratio (M-H, Fixed, 95\% Cl) & Totals not selected \\
\hline 9.1 Children & 2 & & Risk Ratio (M-H, Fixed, 95\% Cl) & $0.0[0.0,0.0]$ \\
\hline 10 Rise in respiratory rate & 2 & & Mean Difference (IV, Fixed, 95\% CI) & Totals not selected \\
\hline 10.1 Adults & 1 & & Mean Difference (IV, Fixed, 95\% CI) & $0.0[0.0,0.0]$ \\
\hline 10.2 Children & 1 & & Mean Difference (IV, Fixed, 95\% CI) & $0.0[0.0,0.0]$ \\
\hline
\end{tabular}


Analysis 2.1. Comparison 2 Spacer (chamber) versus nebuliser

(single-treatment studies), Outcome 1 Hospital admission.

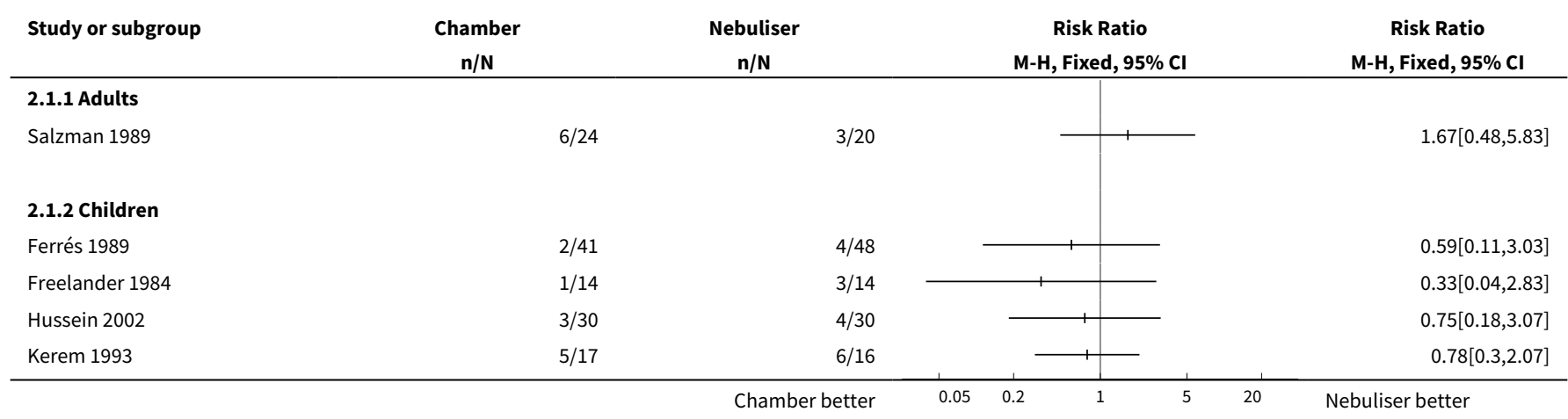

Analysis 2.2. Comparison 2 Spacer (chamber) versus nebuliser (single-treatment studies), Outcome 2 Final peak flow (\% predicted).

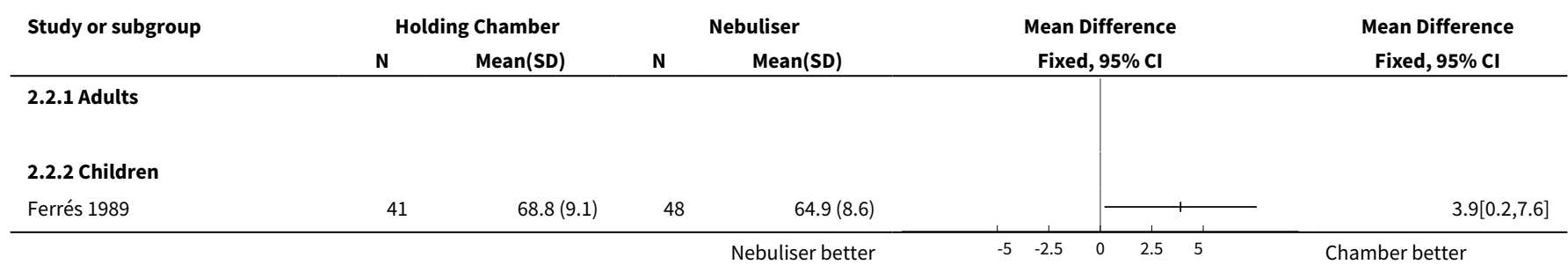

Analysis 2.3. Comparison 2 Spacer (chamber) versus nebuliser (singletreatment studies), Outcome 330 minute rise in $\mathrm{FEV}_{1}$ (\% predicted).

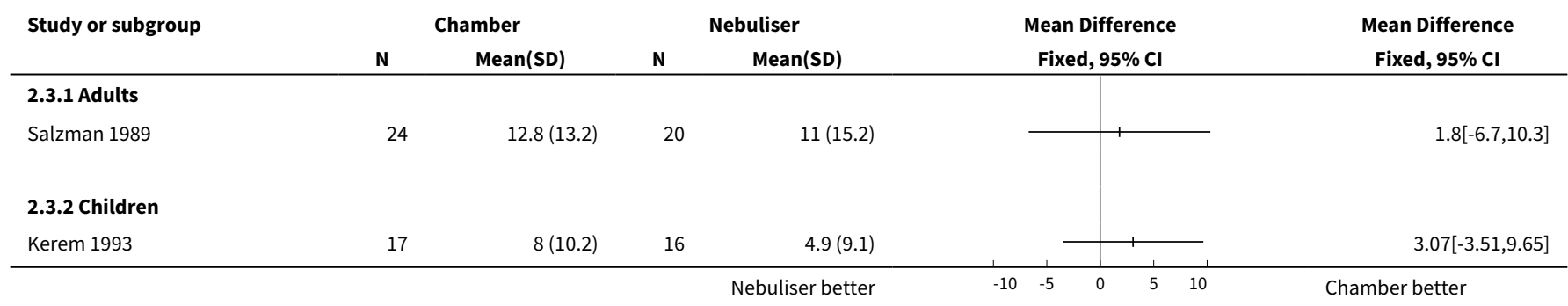

Analysis 2.4. Comparison 2 Spacer (chamber) versus nebuliser (singletreatment studies), Outcome 415 minute rise in FEV $_{1}$ (\% predicted).

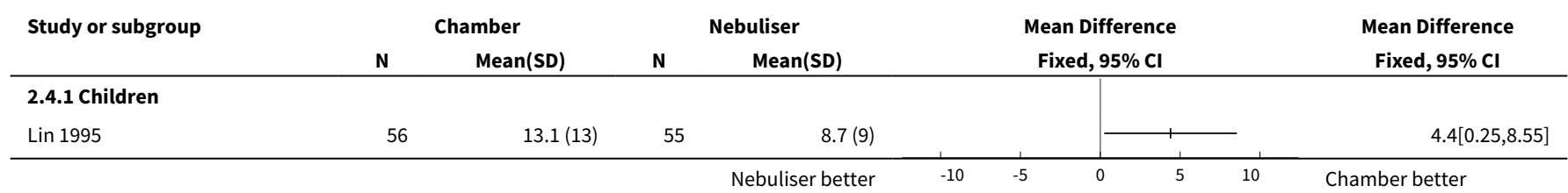


Analysis 2.5. Comparison 2 Spacer (chamber) versus nebuliser (singletreatment studies), Outcome $5 \mathbf{3 0}$ minute rise in peak flow (\% predicted).

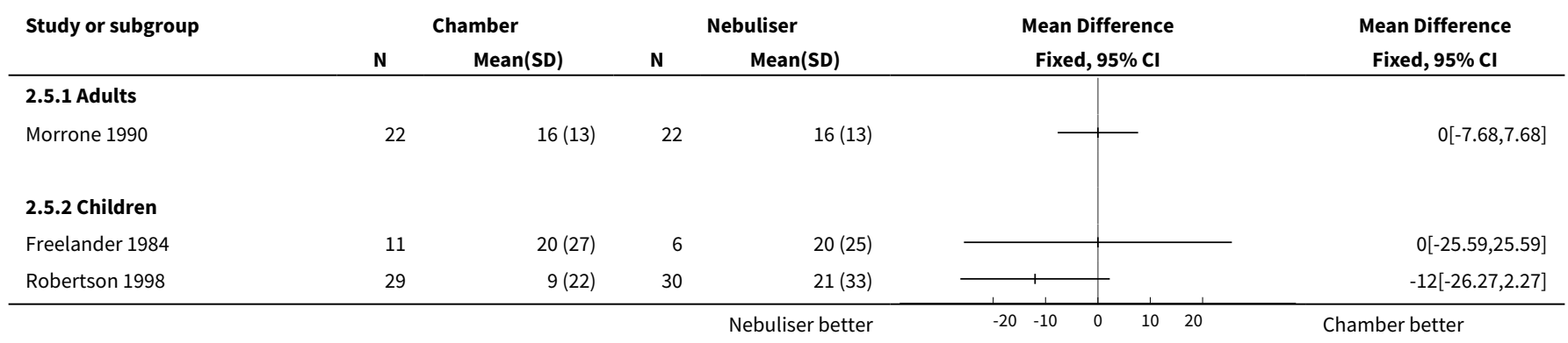

Analysis 2.6. Comparison 2 Spacer (chamber) versus nebuliser (singletreatment studies), Outcome 615 minute rise in peak flow (\% predicted).

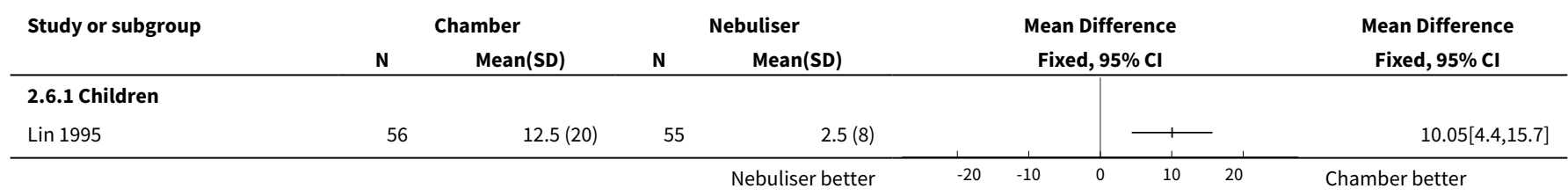

Analysis 2.7. Comparison 2 Spacer (chamber) versus nebuliser (single-treatment studies), Outcome 7 Rise in pulse rate (\% baseline).

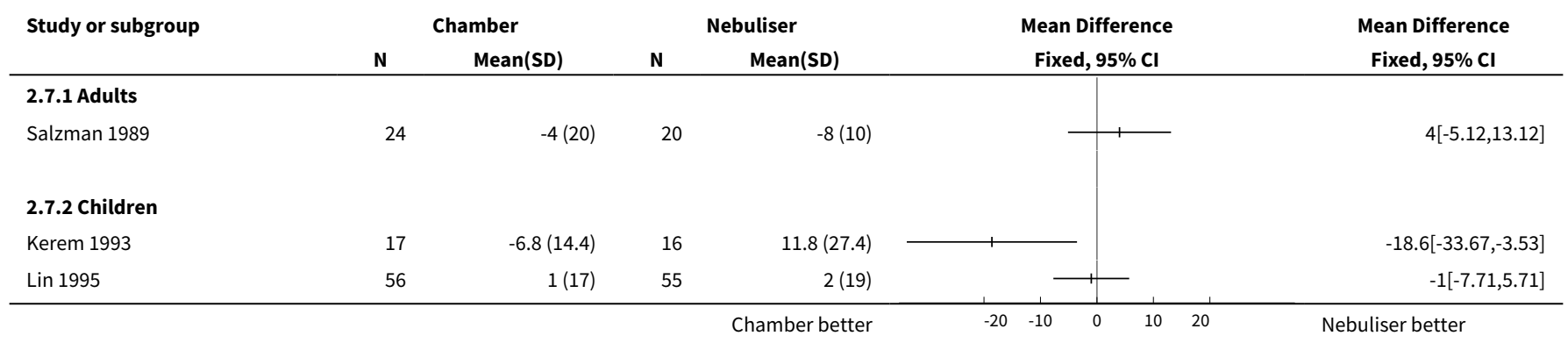

Analysis 2.8. Comparison 2 Spacer (chamber) versus nebuliser (singletreatment studies), Outcome 8 Number of participants developing tremor.

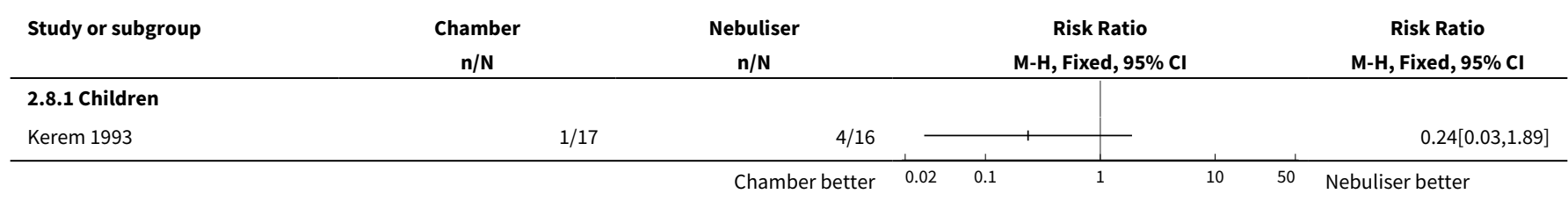


Analysis 2.9. Comparison 2 Spacer (chamber) versus nebuliser (single-treatment studies), Outcome 9 Number of participants with deterioration in blood gases.

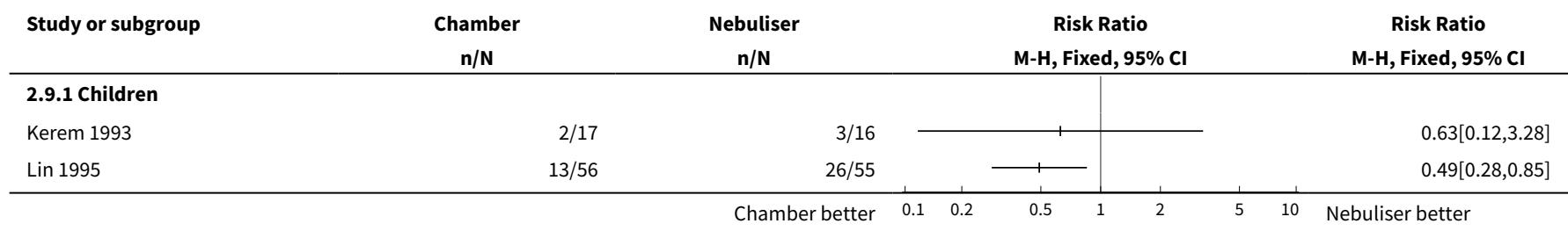

Analysis 2.10. Comparison 2 Spacer (chamber) versus nebuliser (single-treatment studies), Outcome 10 Rise in respiratory rate.

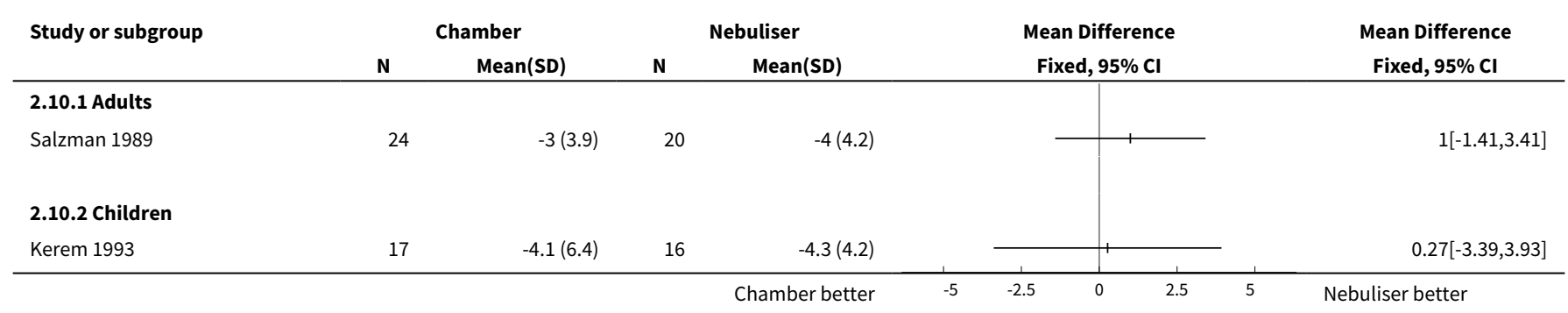

\section{Comparison 3. Spacer (chamber) versus nebuliser (inpatient studies)}

\begin{tabular}{|c|c|c|c|c|}
\hline Outcome or subgroup title & $\begin{array}{l}\text { No. of } \\
\text { studies }\end{array}$ & $\begin{array}{l}\text { No. of } \\
\text { partici- } \\
\text { pants }\end{array}$ & Statistical method & Effect size \\
\hline $\begin{array}{l}1 \text { Duration of hospital admission } \\
\text { (days) }\end{array}$ & 3 & & Mean Difference (IV, Fixed, 95\% CI) & Subtotals only \\
\hline 1.1 Adults & 1 & 18 & Mean Difference (IV, Fixed, 95\% CI) & $-0.60[-3.23,2.03]$ \\
\hline 1.2 Children & 2 & 75 & Mean Difference (IV, Fixed, 95\% CI) & $0.33[-0.10,0.76]$ \\
\hline $\begin{array}{l}2 \text { Number of hours until reached } 4- \\
\text { hourly dosing regimen }\end{array}$ & 1 & & Mean Difference (IV, Fixed, 95\% CI) & Totals not selected \\
\hline 2.1 Adults & 0 & & Mean Difference (IV, Fixed, 95\% CI) & $0.0[0.0,0.0]$ \\
\hline 2.2 Children & 1 & & Mean Difference (IV, Fixed, 95\% CI) & $0.0[0.0,0.0]$ \\
\hline $\begin{array}{l}3 \text { Total number of inhaled doses re- } \\
\text { ceived }\end{array}$ & 1 & & Mean Difference (IV, Fixed, 95\% CI) & Totals not selected \\
\hline 3.1 Adults & 0 & & Mean Difference (IV, Fixed, 95\% CI) & $0.0[0.0,0.0]$ \\
\hline 3.2 Children & 1 & & Mean Difference (IV, Fixed, 95\% CI) & $0.0[0.0,0.0]$ \\
\hline $\begin{array}{l}4 \text { Number of participants returning } \\
\text { to normal PEFR and respiratory score } \\
\text { levels (end of study) }\end{array}$ & 1 & & Risk Ratio (M-H, Fixed, 95\% Cl) & Totals not selected \\
\hline
\end{tabular}




\begin{tabular}{|c|c|c|c|c|}
\hline Outcome or subgroup title & $\begin{array}{l}\text { No. of } \\
\text { studies }\end{array}$ & $\begin{array}{l}\text { No. of } \\
\text { partici- } \\
\text { pants }\end{array}$ & Statistical method & Effect size \\
\hline 4.1 Adults & 0 & & Risk Ratio (M-H, Fixed, 95\% Cl) & $0.0[0.0,0.0]$ \\
\hline 4.2 Children & 1 & & Risk Ratio (M-H, Fixed, 95\% Cl) & $0.0[0.0,0.0]$ \\
\hline $\begin{array}{l}5 \text { Number of symptom-free partici- } \\
\text { pants } 14 \text { days post-discharge }\end{array}$ & 1 & & Risk Ratio (M-H, Fixed, 95\% Cl) & Totals not selected \\
\hline 5.1 Adults & 0 & & Risk Ratio (M-H, Fixed, 95\% Cl) & $0.0[0.0,0.0]$ \\
\hline 5.2 Children & 1 & & Risk Ratio (M-H, Fixed, 95\% Cl) & $0.0[0.0,0.0]$ \\
\hline $\begin{array}{l}6 \text { Readmissions in the subsequent } 12 \\
\text { months }\end{array}$ & 1 & & Risk Ratio (M-H, Fixed, 95\% Cl) & Totals not selected \\
\hline 6.1 Adults & 0 & & Risk Ratio (M-H, Fixed, 95\% Cl) & $0.0[0.0,0.0]$ \\
\hline 6.2 Children & 1 & & Risk Ratio (M-H, Fixed, 95\% Cl) & $0.0[0.0,0.0]$ \\
\hline 7 Clinical asthma score (end of trial) & 1 & & Mean Difference (IV, Fixed, 95\% CI) & Totals not selected \\
\hline 7.1 Adults & 0 & & Mean Difference (IV, Fixed, 95\% CI) & $0.0[0.0,0.0]$ \\
\hline 7.2 Children & 1 & & Mean Difference (IV, Fixed, 95\% CI) & $0.0[0.0,0.0]$ \\
\hline $\begin{array}{l}8 \text { Maximum percentage decrease in } \\
\text { respiratory score }\end{array}$ & 1 & & Mean Difference (IV, Fixed, 95\% CI) & Totals not selected \\
\hline 8.1 Adults & 0 & & Mean Difference (IV, Fixed, 95\% CI) & $0.0[0.0,0.0]$ \\
\hline 8.2 Children & 1 & & Mean Difference (IV, Fixed, 95\% CI) & $0.0[0.0,0.0]$ \\
\hline 9 Respiratory rate at discharge & 2 & & Mean Difference (IV, Fixed, 95\% CI) & Subtotals only \\
\hline 9.1 Adults & 0 & 0 & Mean Difference (IV, Fixed, 95\% CI) & $0.0[0.0,0.0]$ \\
\hline 9.2 Children & 2 & 75 & Mean Difference (IV, Fixed, 95\% CI) & $-0.91[-3.20,1.38]$ \\
\hline 10 Heart rate at discharge & 2 & & Mean Difference (IV, Fixed, 95\% CI) & Subtotals only \\
\hline 10.1 Adults & 0 & 0 & Mean Difference (IV, Fixed, 95\% CI) & $0.0[0.0,0.0]$ \\
\hline 10.2 Children & 2 & 76 & Mean Difference (IV, Fixed, 95\% CI) & $1.06[-5.48,7.61]$ \\
\hline 11 Oxygen saturations at discharge & 2 & & Mean Difference (IV, Fixed, 95\% CI) & Subtotals only \\
\hline 11.1 Adults & 0 & 0 & Mean Difference (IV, Fixed, 95\% CI) & $0.0[0.0,0.0]$ \\
\hline 11.2 Children & 2 & 76 & Mean Difference (IV, Fixed, 95\% CI) & $0.12[-0.42,0.66]$ \\
\hline 1230 minute rise in $\mathrm{FEV}_{1}$ & 2 & & $\begin{array}{l}\text { Std. Mean Difference (IV, Fixed, 95\% } \\
\mathrm{CI} \text { ) }\end{array}$ & Totals not selected \\
\hline
\end{tabular}




\begin{tabular}{|c|c|c|c|c|}
\hline Outcome or subgroup title & $\begin{array}{l}\text { No. of } \\
\text { studies }\end{array}$ & $\begin{array}{l}\text { No. of } \\
\text { partici- } \\
\text { pants }\end{array}$ & Statistical method & Effect size \\
\hline 12.1 Adults & 1 & & $\begin{array}{l}\text { Std. Mean Difference (IV, Fixed, 95\% } \\
\mathrm{Cl} \text { ) }\end{array}$ & $0.0[0.0,0.0]$ \\
\hline 12.2 Children & 1 & & $\begin{array}{l}\text { Std. Mean Difference (IV, Fixed, 95\% } \\
\mathrm{Cl} \text { ) }\end{array}$ & $0.0[0.0,0.0]$ \\
\hline 13 Final rise in $\mathrm{FEV}_{1}$ & 2 & & $\begin{array}{l}\text { Std. Mean Difference (IV, Fixed, 95\% } \\
\mathrm{Cl} \text { ) }\end{array}$ & Totals not selected \\
\hline 13.1 Adults & 1 & & $\begin{array}{l}\text { Std. Mean Difference (IV, Fixed, 95\% } \\
\mathrm{Cl} \text { ) }\end{array}$ & $0.0[0.0,0.0]$ \\
\hline 13.2 Children & 1 & & $\begin{array}{l}\text { Std. Mean Difference (IV, Fixed, 95\% } \\
\mathrm{Cl} \text { ) }\end{array}$ & $0.0[0.0,0.0]$ \\
\hline $\begin{array}{l}14 \text { Final rise in peak flow ( } \% \text { change } \\
\text { from baseline) }\end{array}$ & 1 & & Mean Difference (IV, Fixed, 95\% CI) & Totals not selected \\
\hline 14.1 Adults & 0 & & Mean Difference (IV, Fixed, 95\% CI) & $0.0[0.0,0.0]$ \\
\hline 14.2 Children & 1 & & Mean Difference (IV, Fixed, 95\% CI) & $0.0[0.0,0.0]$ \\
\hline
\end{tabular}

Analysis 3.1. Comparison 3 Spacer (chamber) versus nebuliser (inpatient studies), Outcome 1 Duration of hospital admission (days).

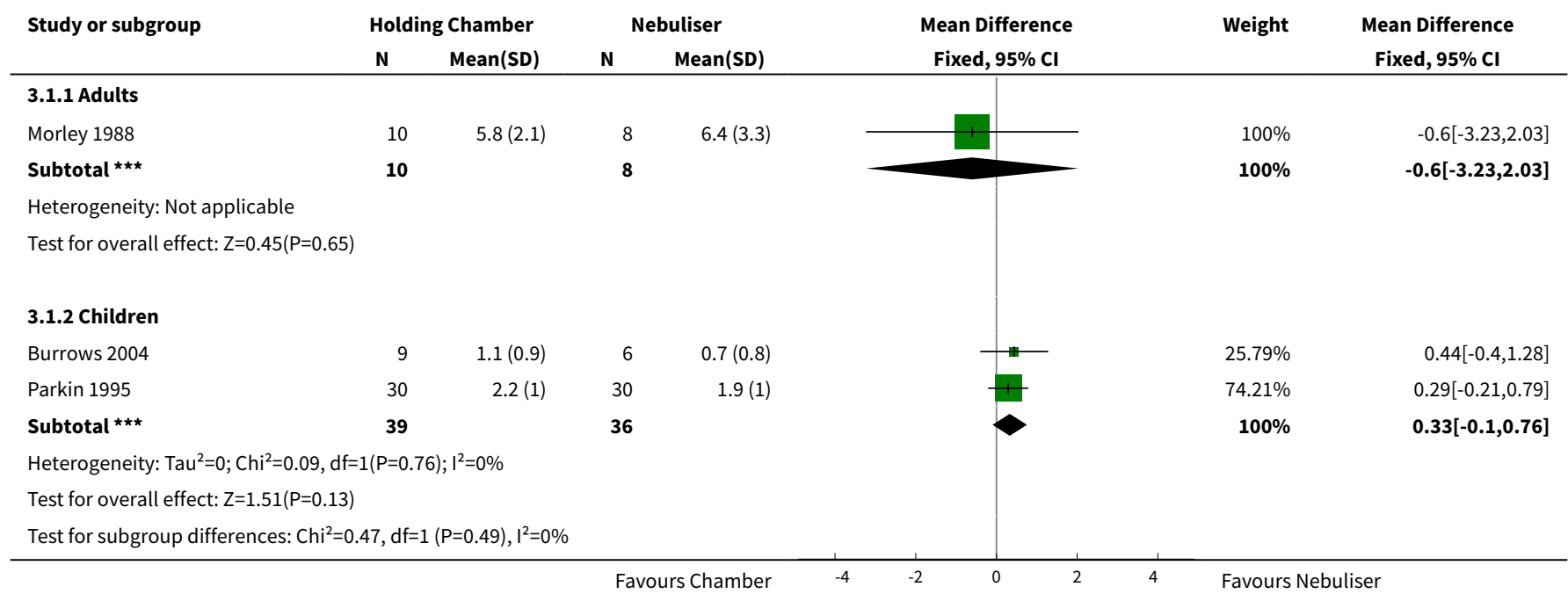


Analysis 3.2. Comparison 3 Spacer (chamber) versus nebuliser (inpatient studies), Outcome 2 Number of hours until reached 4-hourly dosing regimen.

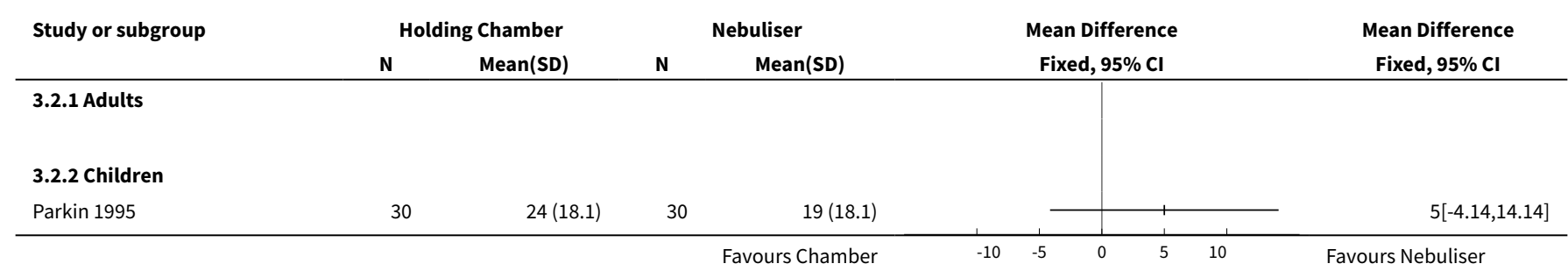

Analysis 3.3. Comparison 3 Spacer (chamber) versus nebuliser (inpatient studies), Outcome 3 Total number of inhaled doses received.

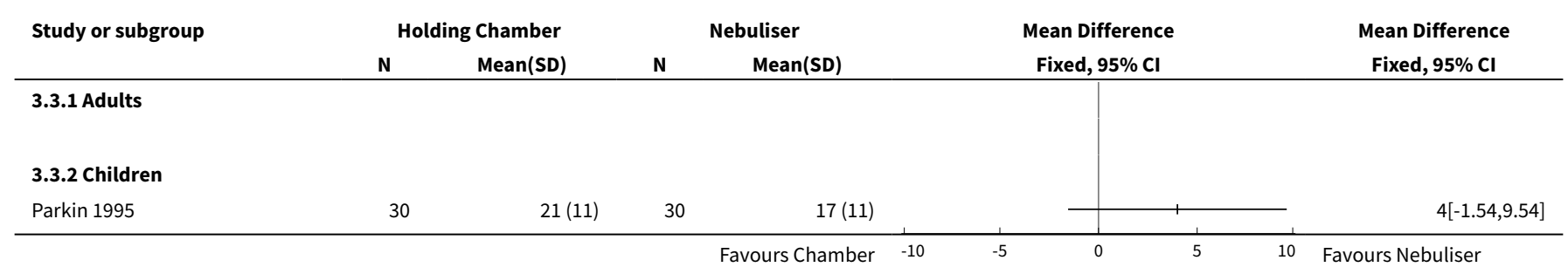

Analysis 3.4. Comparison 3 Spacer (chamber) versus nebuliser (inpatient studies), Outcome 4 Number of participants returning to normal PEFR and respiratory score levels (end of study).

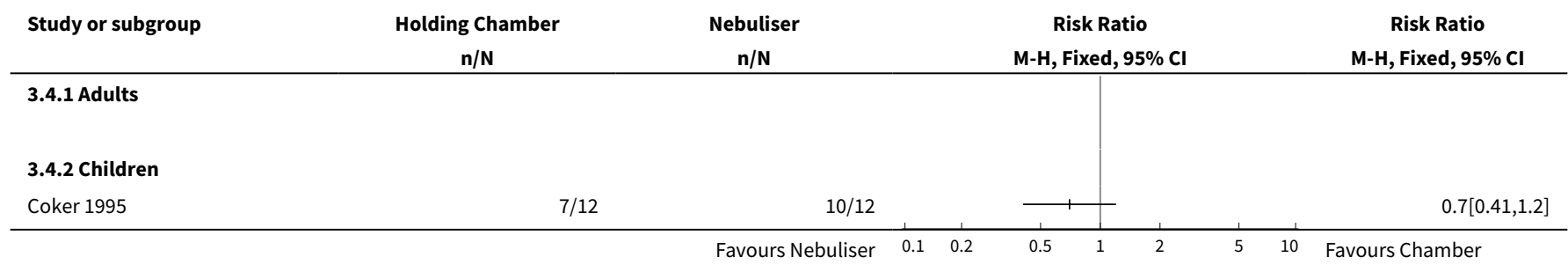

Analysis 3.5. Comparison 3 Spacer (chamber) versus nebuliser (inpatient studies), Outcome 5 Number of symptom-free participants 14 days post-discharge.

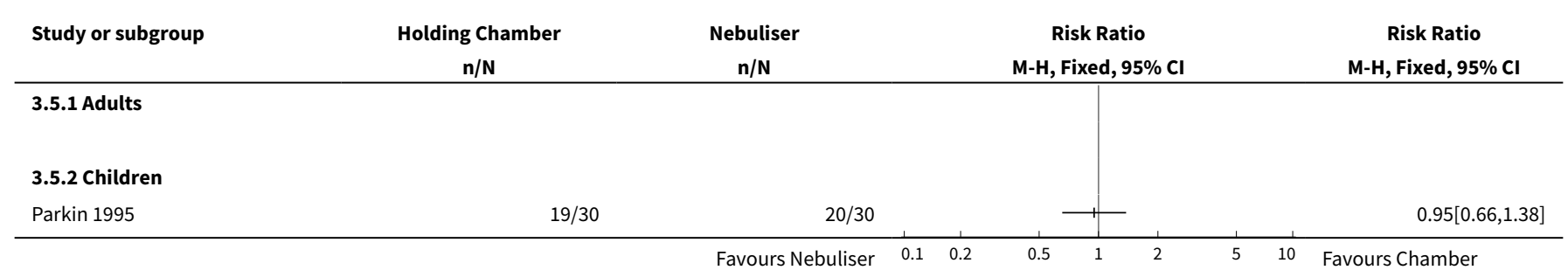


Analysis 3.6. Comparison 3 Spacer (chamber) versus nebuliser (inpatient studies), Outcome 6 Readmissions in the subsequent 12 months.

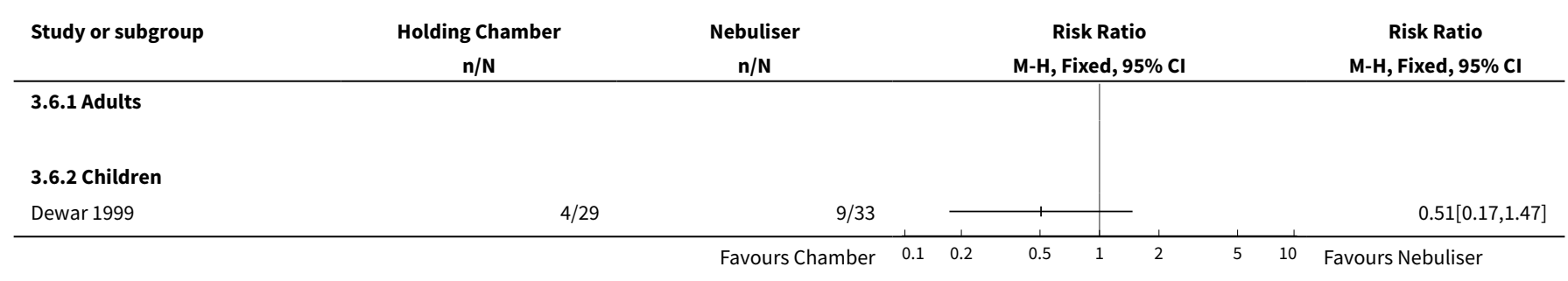

Analysis 3.7. Comparison 3 Spacer (chamber) versus nebuliser (inpatient studies), Outcome 7 Clinical asthma score (end of trial).

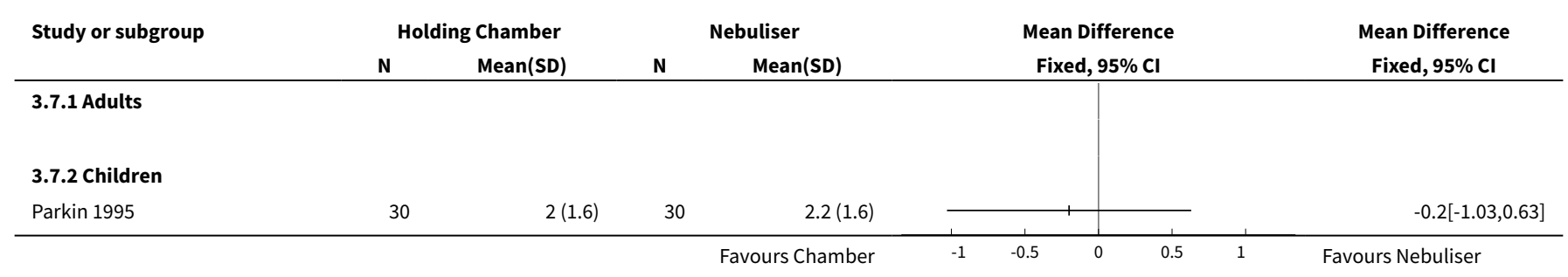

Analysis 3.8. Comparison 3 Spacer (chamber) versus nebuliser (inpatient studies), Outcome 8 Maximum percentage decrease in respiratory score.

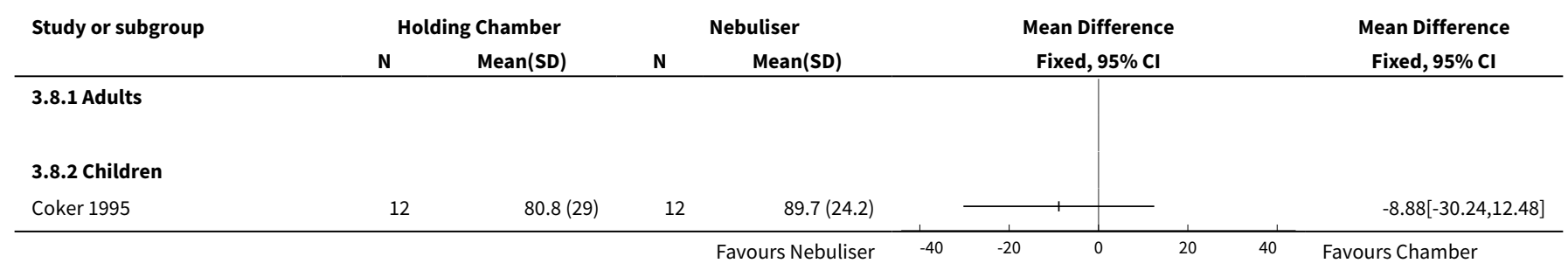

Analysis 3.9. Comparison 3 Spacer (chamber) versus nebuliser (inpatient studies), Outcome 9 Respiratory rate at discharge.

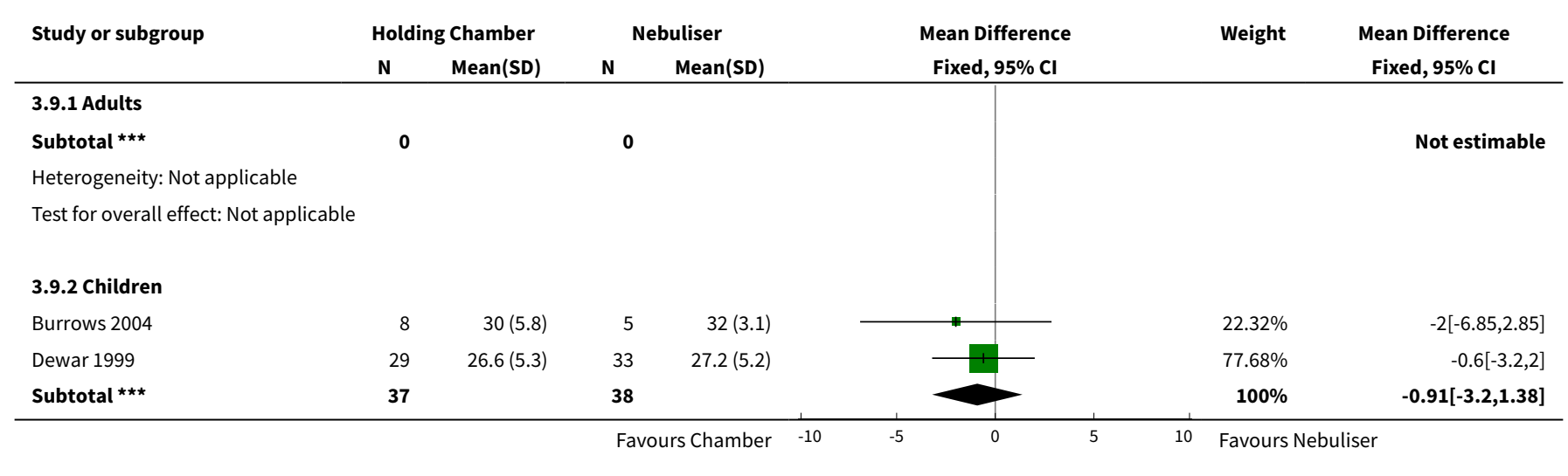




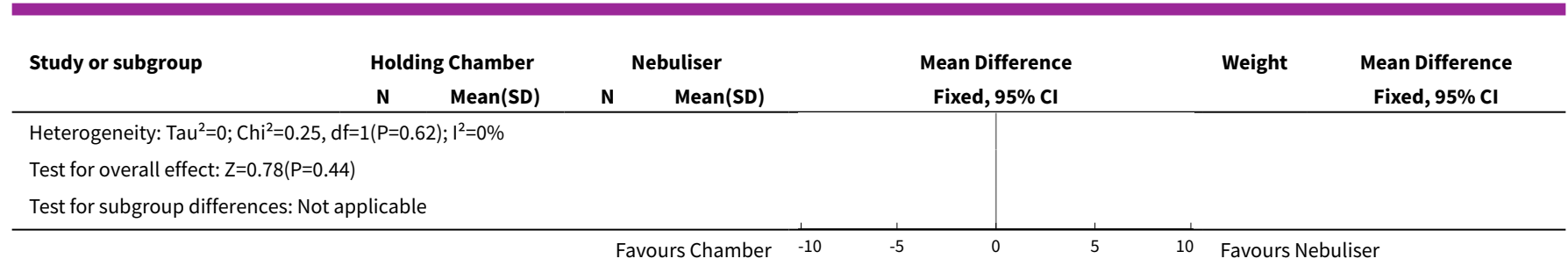

Analysis 3.10. Comparison 3 Spacer (chamber) versus nebuliser (inpatient studies), Outcome 10 Heart rate at discharge.

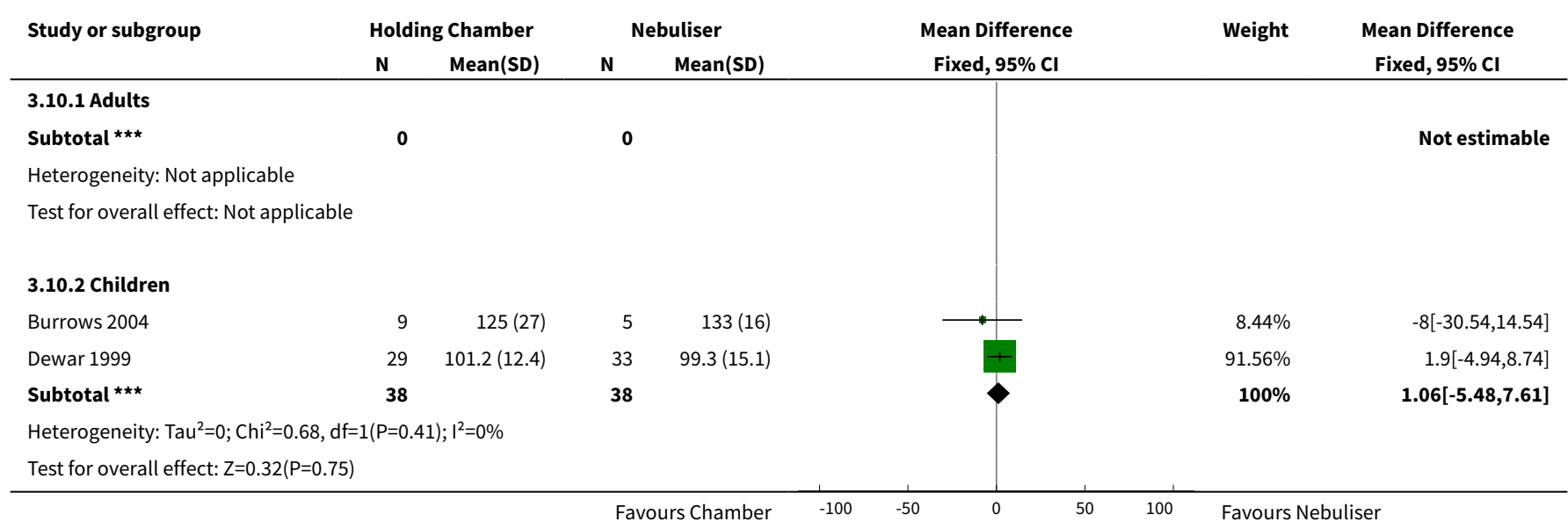

Analysis 3.11. Comparison 3 Spacer (chamber) versus nebuliser (inpatient studies), Outcome 11 Oxygen saturations at discharge.

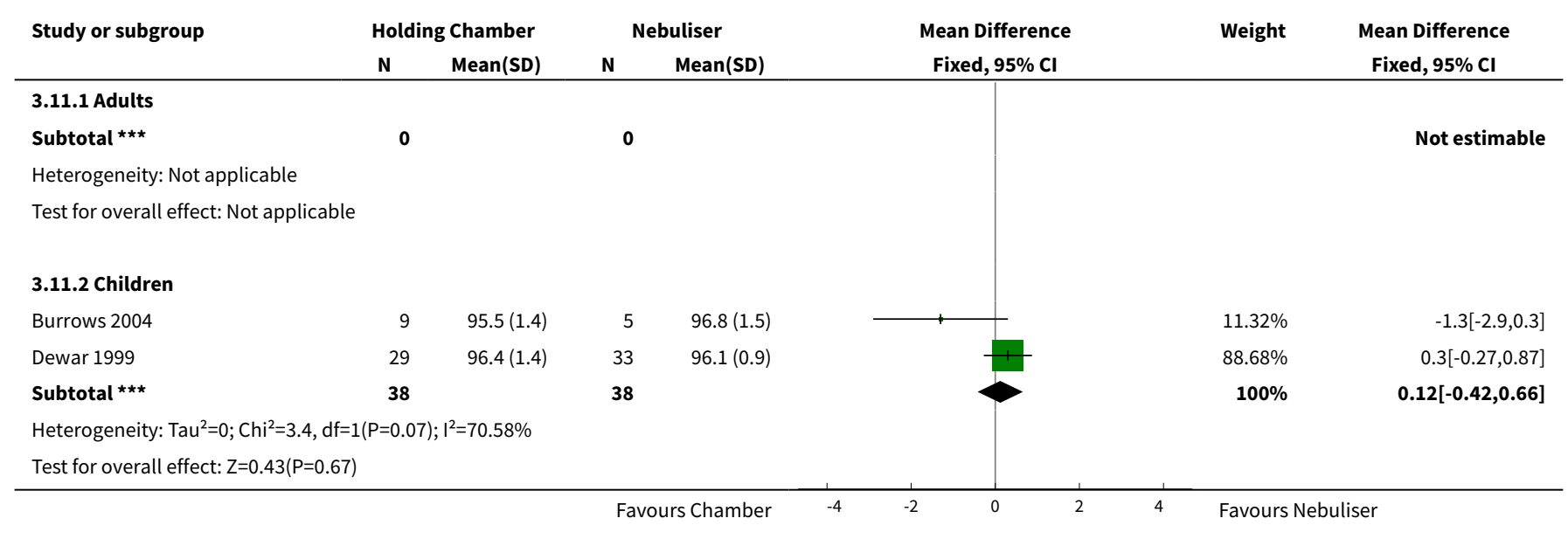


Analysis 3.12. Comparison 3 Spacer (chamber) versus nebuliser (inpatient studies), Outcome 1230 minute rise in $\mathrm{FEV}_{1}$.

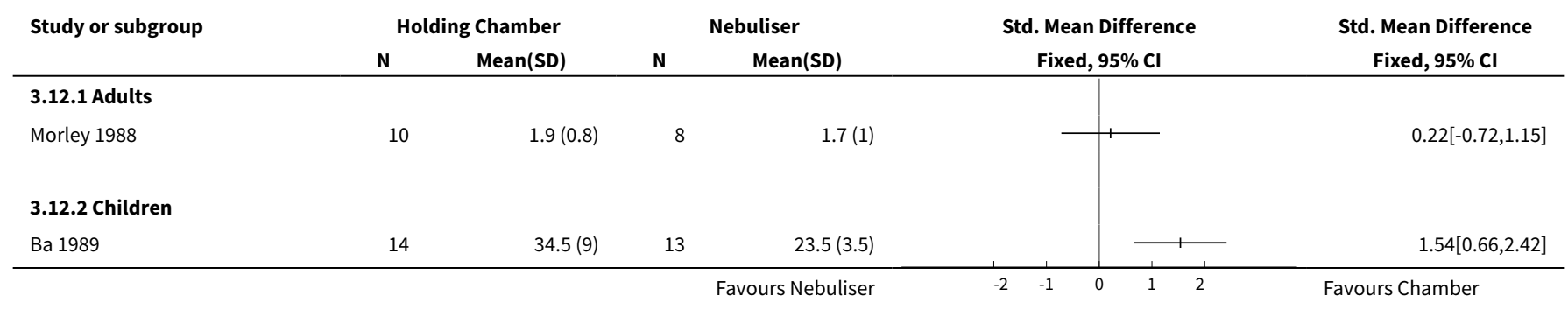

Analysis 3.13. Comparison 3 Spacer (chamber) versus nebuliser (inpatient studies), Outcome 13 Final rise in FEV ${ }_{1}$.

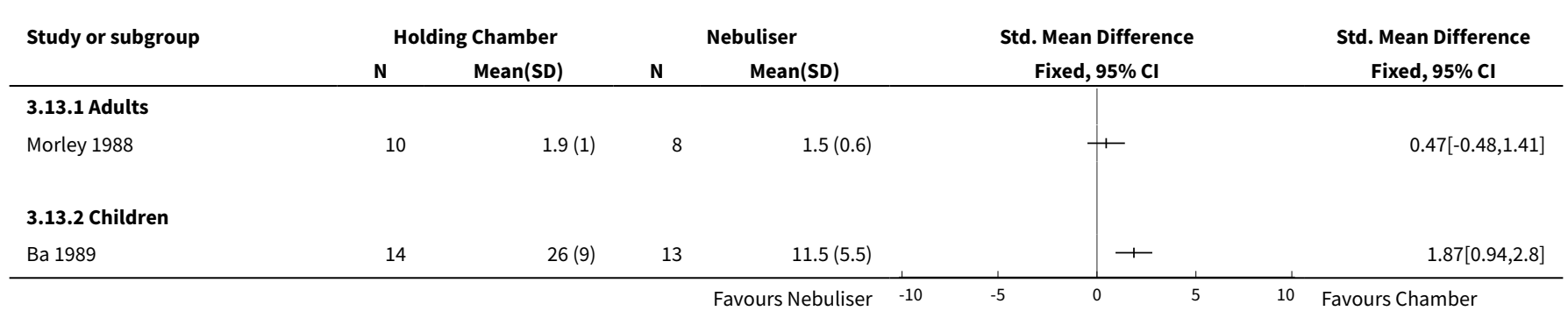

Analysis 3.14. Comparison 3 Spacer (chamber) versus nebuliser (inpatient studies), Outcome 14 Final rise in peak flow (\% change from baseline).

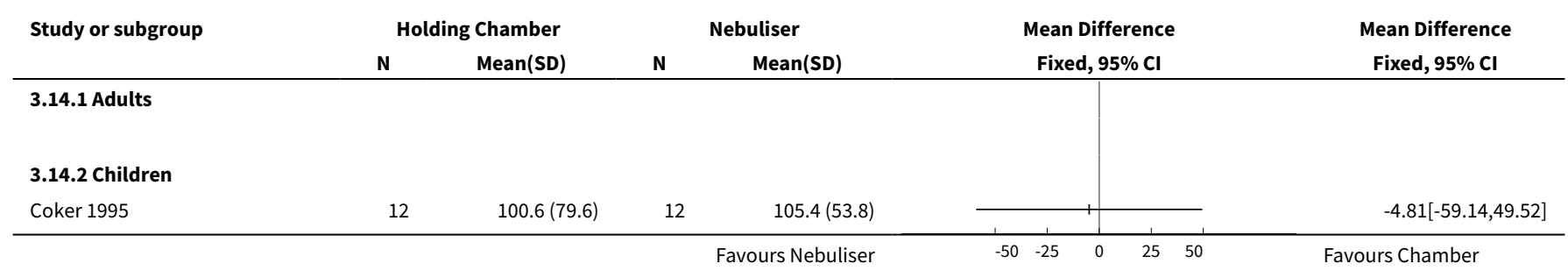

Comparison 4. Spacer (chamber) versus nebuliser (multiple-treatment studies with Volumatic subgroups)

\begin{tabular}{lllll}
\hline Outcome or subgroup title & $\begin{array}{l}\text { No. of } \\
\text { studies }\end{array}$ & $\begin{array}{l}\text { No. of } \\
\text { partici- } \\
\text { pants }\end{array}$ & Statistical method & Effect size \\
\hline 1 Hospital admission & 16 & & $\begin{array}{l}\text { Risk Ratio (M-H, Fixed, 95\% } \\
\text { Cl) }\end{array}$ & Subtotals only \\
\hline 1.1 Adults with other spacers & 6 & 366 & $\begin{array}{l}\text { Risk Ratio (M-H, Fixed, 95\% } \\
\text { Cl) }\end{array}$ & $1.25[0.55,2.84]$ \\
\hline 1.2 Adults with Volumatic & 2 & 166 & $\begin{array}{l}\text { Risk Ratio (M-H, Fixed, 95\% } \\
\text { Cl) }\end{array}$ & $0.84[0.51,1.38]$ \\
\hline
\end{tabular}




\begin{tabular}{|c|c|c|c|c|}
\hline Outcome or subgroup title & $\begin{array}{l}\text { No. of } \\
\text { studies }\end{array}$ & $\begin{array}{l}\text { No. of } \\
\text { partici- } \\
\text { pants }\end{array}$ & Statistical method & Effect size \\
\hline 1.3 Children with other spacers & 6 & 515 & $\begin{array}{l}\text { Risk Ratio (M-H, Fixed, 95\% } \\
\mathrm{Cl})\end{array}$ & $0.61[0.39,0.96]$ \\
\hline 1.4 Children with Volumatic & 2 & 163 & $\begin{array}{l}\text { Risk Ratio (M-H, Fixed, 95\% } \\
\mathrm{Cl})\end{array}$ & $0.57[0.05,6.11]$ \\
\hline $\begin{array}{l}2 \text { Hospital admission or poor response to } \\
\text { treatment }\end{array}$ & 19 & & $\begin{array}{l}\text { Risk Ratio (M-H, Fixed, 95\% } \\
\mathrm{Cl})\end{array}$ & Subtotals only \\
\hline 2.1 Adults with other spacers & 6 & 366 & $\begin{array}{l}\text { Risk Ratio (M-H, Fixed, } 95 \% \\
\mathrm{Cl})\end{array}$ & $1.25[0.55,2.84]$ \\
\hline 2.2 Adults with Volumatic & 2 & 166 & $\begin{array}{l}\text { Risk Ratio (M-H, Fixed, 95\% } \\
\mathrm{Cl})\end{array}$ & $0.84[0.51,1.38]$ \\
\hline 2.3 Children with other spacers & 8 & 635 & $\begin{array}{l}\text { Risk Ratio (M-H, Fixed, 95\% } \\
\mathrm{Cl})\end{array}$ & $0.80[0.55,1.16]$ \\
\hline 2.4 Children with Volumatic & 3 & 223 & $\begin{array}{l}\text { Risk Ratio (M-H, Fixed, 95\% } \\
\mathrm{Cl})\end{array}$ & $1.29[0.79,2.13]$ \\
\hline $\begin{array}{l}3 \text { Duration in emergency department (min- } \\
\text { utes). }\end{array}$ & 4 & & $\begin{array}{l}\text { Mean Difference (IV, Random, } \\
95 \% \mathrm{CI})\end{array}$ & Subtotals only \\
\hline 3.1 Adults with other spacers & 1 & 35 & $\begin{array}{l}\text { Mean Difference (IV, Random, } \\
95 \% \mathrm{Cl})\end{array}$ & $-9.0[-42.91,24.91]$ \\
\hline 3.2 Adults with Volumatic & 1 & 97 & $\begin{array}{l}\text { Mean Difference (IV, Random, } \\
95 \% \mathrm{CI} \text { ) }\end{array}$ & $15.00[-22.65,52.65]$ \\
\hline 3.3 Children with other spacers & 2 & 348 & $\begin{array}{l}\text { Mean Difference (IV, Random, } \\
95 \% \mathrm{CI} \text { ) }\end{array}$ & $-29.89[-40.47,-19.32]$ \\
\hline 4 Final rise in $\mathrm{FEV}_{1}$ (\% predicted) & 7 & & $\begin{array}{l}\text { Mean Difference (IV, Fixed, } \\
95 \% \mathrm{CI} \text { ) }\end{array}$ & Subtotals only \\
\hline 4.1 Adults with other spacers & 3 & 168 & $\begin{array}{l}\text { Mean Difference (IV, Fixed, } \\
95 \% \mathrm{CI} \text { ) }\end{array}$ & $0.30[-4.70,5.30]$ \\
\hline 4.2 Adults with Volumatic & 2 & 119 & $\begin{array}{l}\text { Mean Difference (IV, Fixed, } \\
95 \% \mathrm{CI} \text { ) }\end{array}$ & $1.20[-4.13,6.53]$ \\
\hline 4.3 Children with other spacers & 1 & 30 & $\begin{array}{l}\text { Mean Difference (IV, Fixed, } \\
95 \% \mathrm{CI} \text { ) }\end{array}$ & $0.0[-6.17,6.17]$ \\
\hline 4.4 Children with Volumatic & 1 & 18 & $\begin{array}{l}\text { Mean Difference (IV, Fixed, } \\
95 \% \mathrm{CI} \text { ) }\end{array}$ & $9.8[-9.41,29.01]$ \\
\hline 530 minute rise in $\mathrm{FEV}_{1}$ (\% predicted) & 2 & & $\begin{array}{l}\text { Mean Difference (IV, Fixed, } \\
95 \% \mathrm{CI} \text { ) }\end{array}$ & Subtotals only \\
\hline 5.1 Adults with other spacers & 1 & 53 & $\begin{array}{l}\text { Mean Difference (IV, Fixed, } \\
95 \% \mathrm{CI} \text { ) }\end{array}$ & $-3.80[-8.51,0.91]$ \\
\hline
\end{tabular}




\begin{tabular}{|c|c|c|c|c|}
\hline Outcome or subgroup title & $\begin{array}{l}\text { No. of } \\
\text { studies }\end{array}$ & $\begin{array}{l}\text { No. of } \\
\text { partici- } \\
\text { pants }\end{array}$ & Statistical method & Effect size \\
\hline 5.2 Adults with Volumatic & 1 & 97 & $\begin{array}{l}\text { Mean Difference (IV, Fixed, } \\
95 \% \mathrm{Cl} \text { ) }\end{array}$ & $1.5[-3.07,6.07]$ \\
\hline $\begin{array}{l}6 \text { Severe asthmatics final rise in } \mathrm{FEV}_{1}(\% \text { pre- } \\
\text { dicted) }\end{array}$ & 4 & & $\begin{array}{l}\text { Mean Difference (IV, Fixed, } \\
95 \% \mathrm{Cl} \text { ) }\end{array}$ & Subtotals only \\
\hline 6.1 Adults with other spacers & 3 & 55 & $\begin{array}{l}\text { Mean Difference (IV, Fixed, } \\
95 \% \mathrm{CI})\end{array}$ & $0.86[-6.77,8.48]$ \\
\hline 6.2 Adults with Volumatic & 1 & 39 & $\begin{array}{l}\text { Mean Difference (IV, Fixed, } \\
95 \% \mathrm{CI})\end{array}$ & $2.90[-7.21,13.01]$ \\
\hline 7 Final rise in peak flow (\% predicted) & 5 & & $\begin{array}{l}\text { Mean Difference (IV, Fixed, } \\
95 \% \mathrm{CI} \text { ) }\end{array}$ & Subtotals only \\
\hline 7.1 Adults with Volumatic & 2 & 119 & $\begin{array}{l}\text { Mean Difference (IV, Fixed, } \\
95 \% \mathrm{Cl} \text { ) }\end{array}$ & $-0.39[-4.77,3.98]$ \\
\hline 7.2 Children with other spacers & 2 & 148 & $\begin{array}{l}\text { Mean Difference (IV, Fixed, } \\
95 \% \mathrm{Cl} \text { ) }\end{array}$ & $-3.75[-9.95,2.45]$ \\
\hline 7.3 Children with Volumatic & 1 & 18 & $\begin{array}{l}\text { Mean Difference (IV, Fixed, } \\
95 \% \mathrm{CI} \text { ) }\end{array}$ & $4.10[-14.81,23.01]$ \\
\hline 830 minute rise in peak flow (\% predicted) & 1 & & $\begin{array}{l}\text { Mean Difference (IV, Fixed, } \\
95 \% \mathrm{CI} \text { ) }\end{array}$ & Totals not selected \\
\hline 8.1 Adults with Volumatic & 1 & & $\begin{array}{l}\text { Mean Difference (IV, Fixed, } \\
95 \% \mathrm{CI} \text { ) }\end{array}$ & $0.0[0.0,0.0]$ \\
\hline 9 Rise in pulse rate (\% baseline) & 13 & & $\begin{array}{l}\text { Mean Difference (IV, Fixed, } \\
95 \% \mathrm{CI} \text { ) }\end{array}$ & Subtotals only \\
\hline 9.1 Adults with other spacers & 3 & 168 & $\begin{array}{l}\text { Mean Difference (IV, Fixed, } \\
95 \% \mathrm{CI})\end{array}$ & $-2.28[-7.81,3.24]$ \\
\hline 9.2 Adults with Volumatic & 3 & 188 & $\begin{array}{l}\text { Mean Difference (IV, Fixed, } \\
95 \% \mathrm{CI} \text { ) }\end{array}$ & $-0.16[-3.89,3.58]$ \\
\hline 9.3 Children with other spacers & 5 & 464 & $\begin{array}{l}\text { Mean Difference (IV, Fixed, } \\
95 \% \mathrm{CI} \text { ) }\end{array}$ & $-6.80[-9.14,-4.45]$ \\
\hline 9.4 Children with Volumatic & 2 & 78 & $\begin{array}{l}\text { Mean Difference (IV, Fixed, } \\
95 \% \mathrm{CI} \text { ) }\end{array}$ & $-6.73[-11.24,-2.23]$ \\
\hline
\end{tabular}


Analysis 4.1. Comparison 4 Spacer (chamber) versus nebuliser (multipletreatment studies with Volumatic subgroups), Outcome 1 Hospital admission.

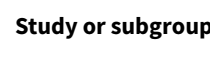

$\begin{array}{cc}\begin{array}{c}\text { Holding } \\ \text { Chamber }\end{array} & \text { Nebuliser } \\ \mathrm{n} / \mathrm{N} & \mathrm{n} / \mathrm{N}\end{array}$

$\mathbf{n} / \mathbf{N}$

Risk Ratio

M-H, Fixed, $95 \% \mathrm{Cl}$

\subsubsection{Adults with other spacers}

Colacone 1993

$n / N$

N

$\begin{array}{rr}1 / 40 & 0 / 40 \\ 1 / 29 & 2 / 29 \\ 1 / 15 & 1 / 20 \\ 0 / 9 & 0 / 9 \\ 4 / 27 & 5 / 26 \\ 5 / 68 & 1 / 54 \\ \mathbf{1 8 8} & \mathbf{1 7 8}\end{array}$

Subtotal $(95 \% \mathrm{Cl})$

Total events: 12 (Holding Chamber), 9 (Nebuliser)

Heterogeneity: $\mathrm{Tau}^{2}=0 ; \mathrm{Chi}^{2}=2.66, \mathrm{df}=4(\mathrm{P}=0.62) ; \mathrm{I}^{2}=0 \%$

Test for overall effect: $Z=0.54(P=0.59)$

\subsubsection{Adults with Volumatic}

Rodrigo 1993

Rodriguez 1999

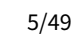

$14 / 36$

Subtotal $(95 \% \mathrm{Cl})$

85

Total events: 19 (Holding Chamber), 21 (Nebuliser) Heterogeneity: $\mathrm{Tau}^{2}=0 ; \mathrm{Chi}^{2}=0.51, \mathrm{df}=1(\mathrm{P}=0.48) ; \mathrm{I}^{2}=0 \%$

Test for overall effect: $Z=0.68(P=0.49)$

\subsubsection{Children with other spacers}

$\begin{array}{lr}\text { Chong-Neto } 2005 & 0 / 20 \\ \text { Chou } 1995 & 4 / 71 \\ \text { Jamalvi } 2006 & 4 / 84 \\ \text { Leversha } 2000 & 10 / 30 \\ \text { Ploin } 2000 & 3 / 31 \\ \text { Williams } 1996 & 2 / 42 \\ \text { Subtotal (95\% Cl) } & \mathbf{2 7 8} \\ \text { Total events: } 23 \text { (Holding Chamber), 35 (Nebuliser) } \\ \text { Heterogeneity: } \text { Tau }^{2}=0 ; \text { Chi }^{2}=1.33, \mathrm{df}=4(\mathrm{P}=0.86) ; \text { I }^{2}=0 \% \\ \text { Test for overall effect: } \mathrm{Z}=2.15(\mathrm{P}=0.03)\end{array}$

\subsubsection{Children with Volumatic}

Direkwatanachai 2008

Vazquez 1992

Subtotal $(95 \% \mathrm{Cl})$

$\begin{array}{rr}1 / 68 & 2 / 77 \\ 0 / 9 & 0 / 9 \\ \mathbf{7 7} & \mathbf{8 6}\end{array}$

Total events: 1 (Holding Chamber), 2 (Nebuliser)

Heterogeneity: Not applicable

Test for overall effect: $\mathrm{Z}=0.47(\mathrm{P}=0.64)$

Test for subgroup differences: $\mathrm{Chi}^{2}=2.6, \mathrm{df}=1(\mathrm{P}=0.46), \mathrm{I}^{2}=0 \%$

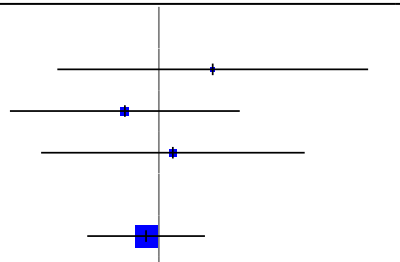

$18.55 \%$

$81.45 \%$

$100 \%$

$1.22[0.35,4.29]$

$0.75[0.45,1.28]$

$0.84[0.51,1.38]$
Not estimable

$0.91[0.25,3.27]$

$0.45[0.14,1.47]$

$0.56[0.31,1]$

$1.03[0.23,4.73]$

$0.43[0.07,2.81]$

$0.61[0.39,0.96]$ 
Analysis 4.2. Comparison 4 Spacer (chamber) versus nebuliser (multiple-treatment studies with Volumatic subgroups), Outcome 2 Hospital admission or poor response to treatment.

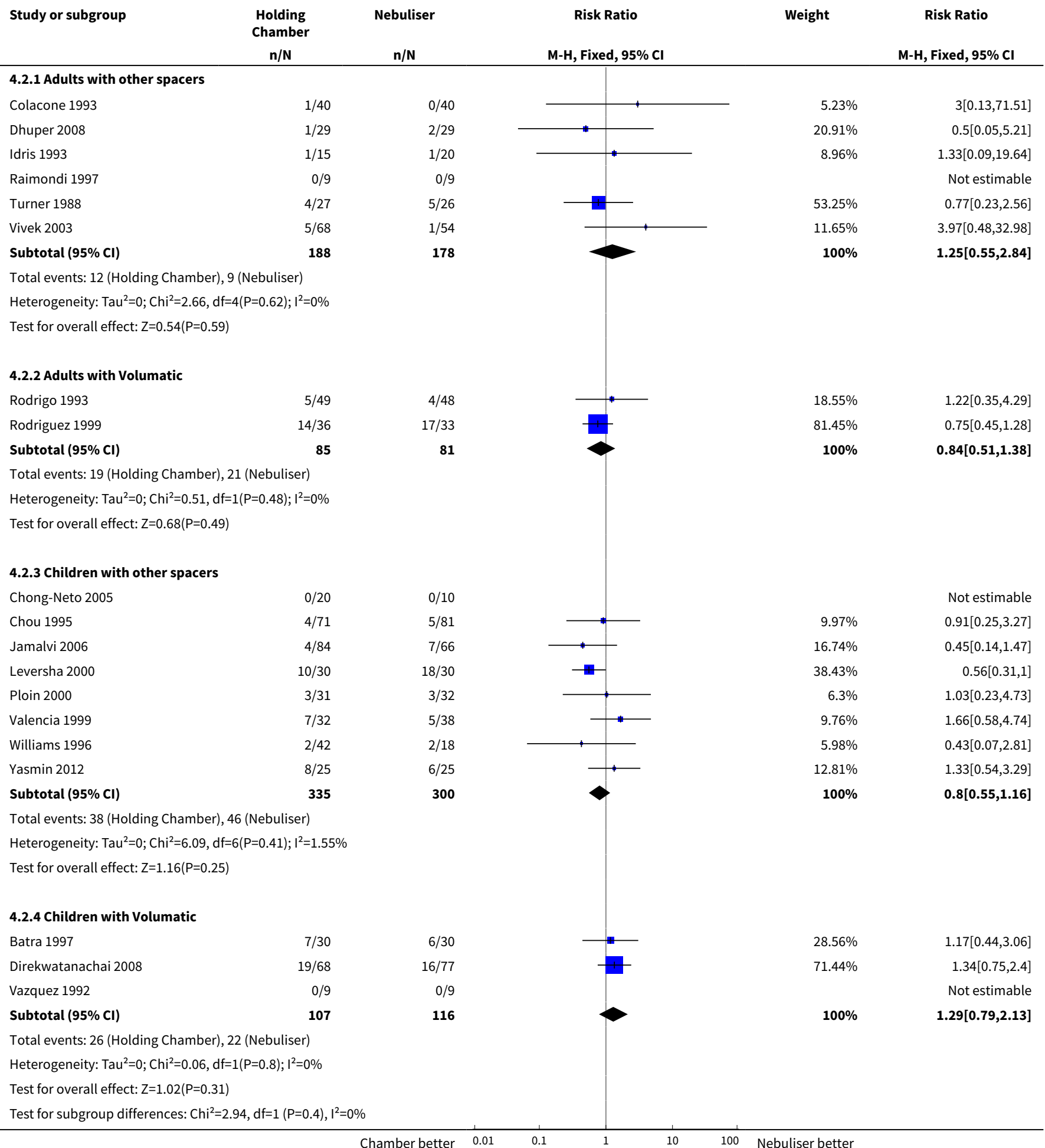


Analysis 4.3. Comparison 4 Spacer (chamber) versus nebuliser (multiple-treatment studies with Volumatic subgroups), Outcome 3 Duration in emergency department (minutes)..

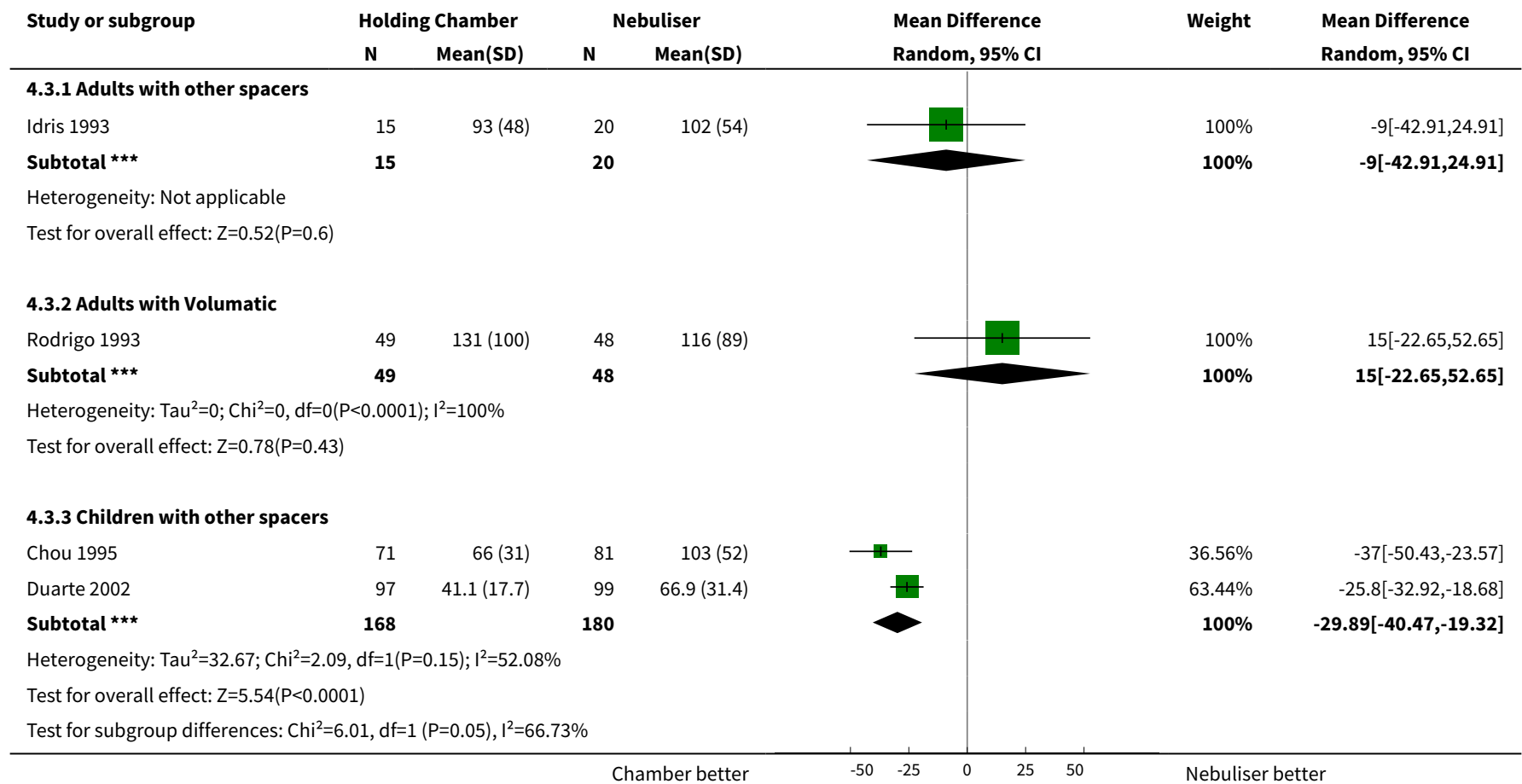

\section{Analysis 4.4. Comparison 4 Spacer (chamber) versus nebuliser (multiple-treatment studies with Volumatic subgroups), Outcome 4 Final rise in FEV (\% predicted).}

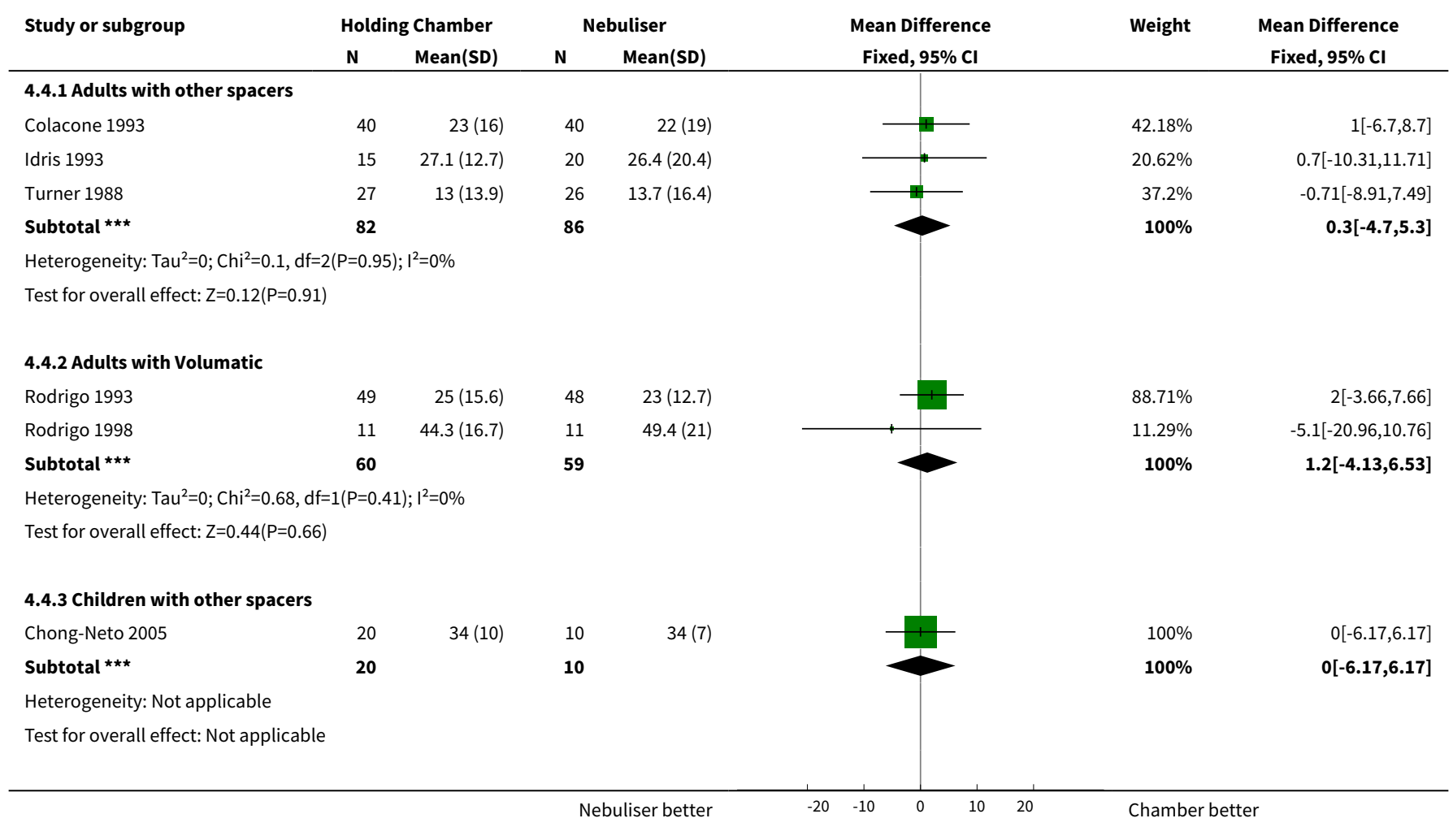




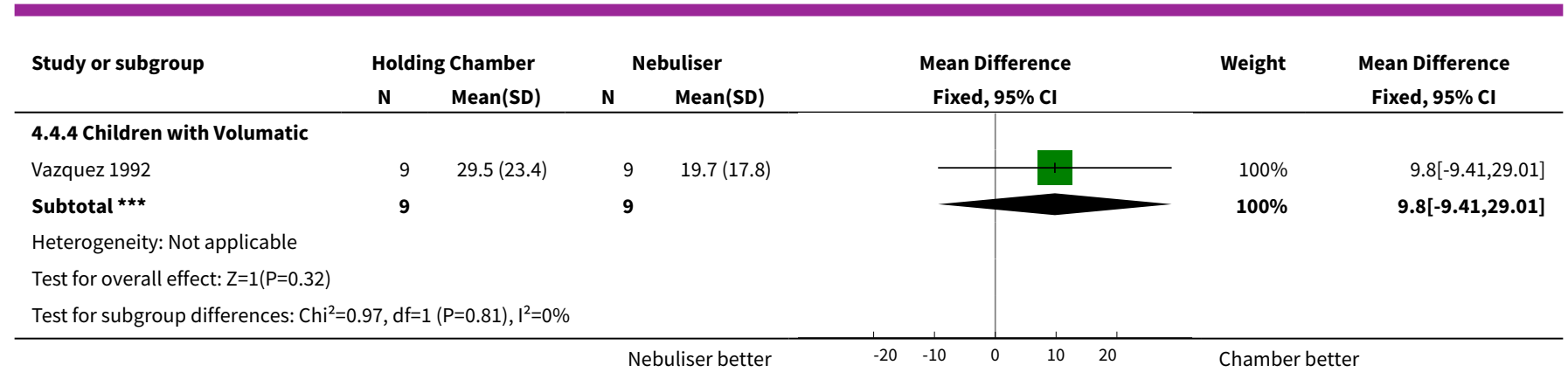

Analysis 4.5. Comparison 4 Spacer (chamber) versus nebuliser (multiple-treatment studies with Volumatic subgroups), Outcome 530 minute rise in $\mathrm{FEV}_{1}$ (\% predicted).

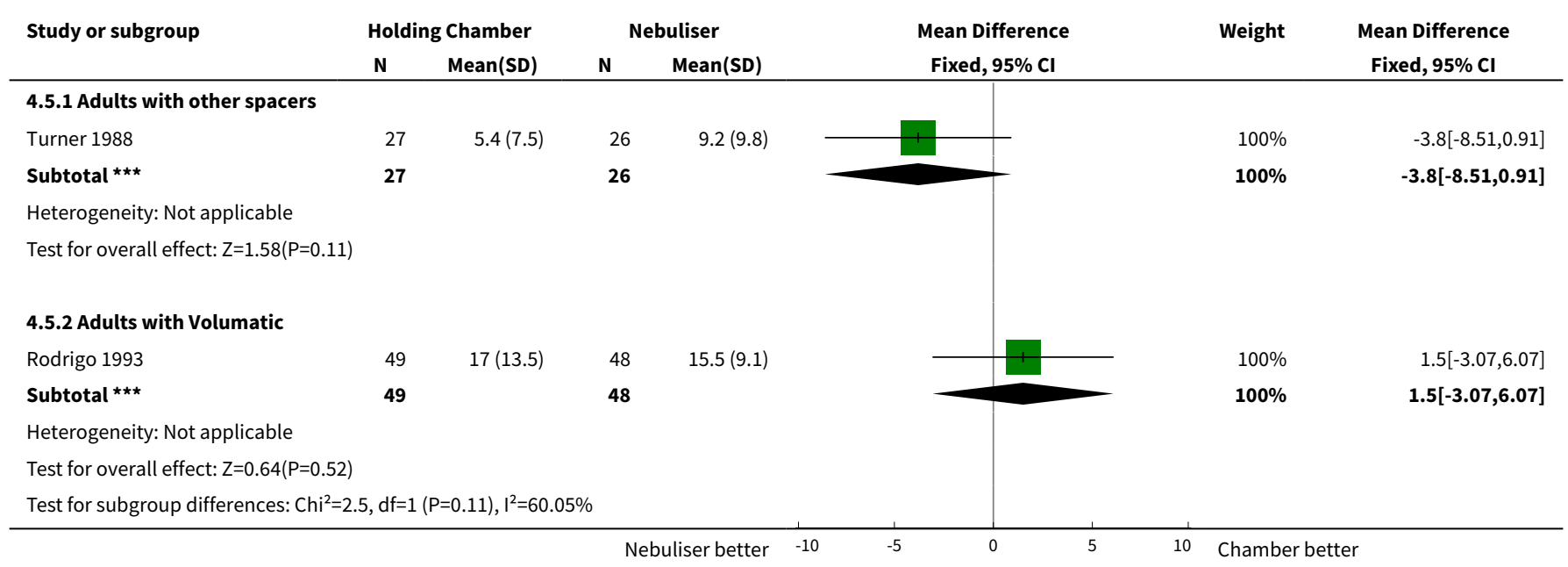

\section{Analysis 4.6. Comparison 4 Spacer (chamber) versus nebuliser (multiple-treatment studies}

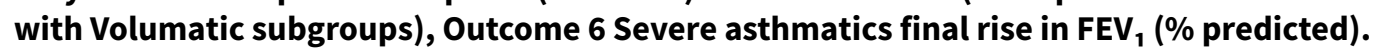

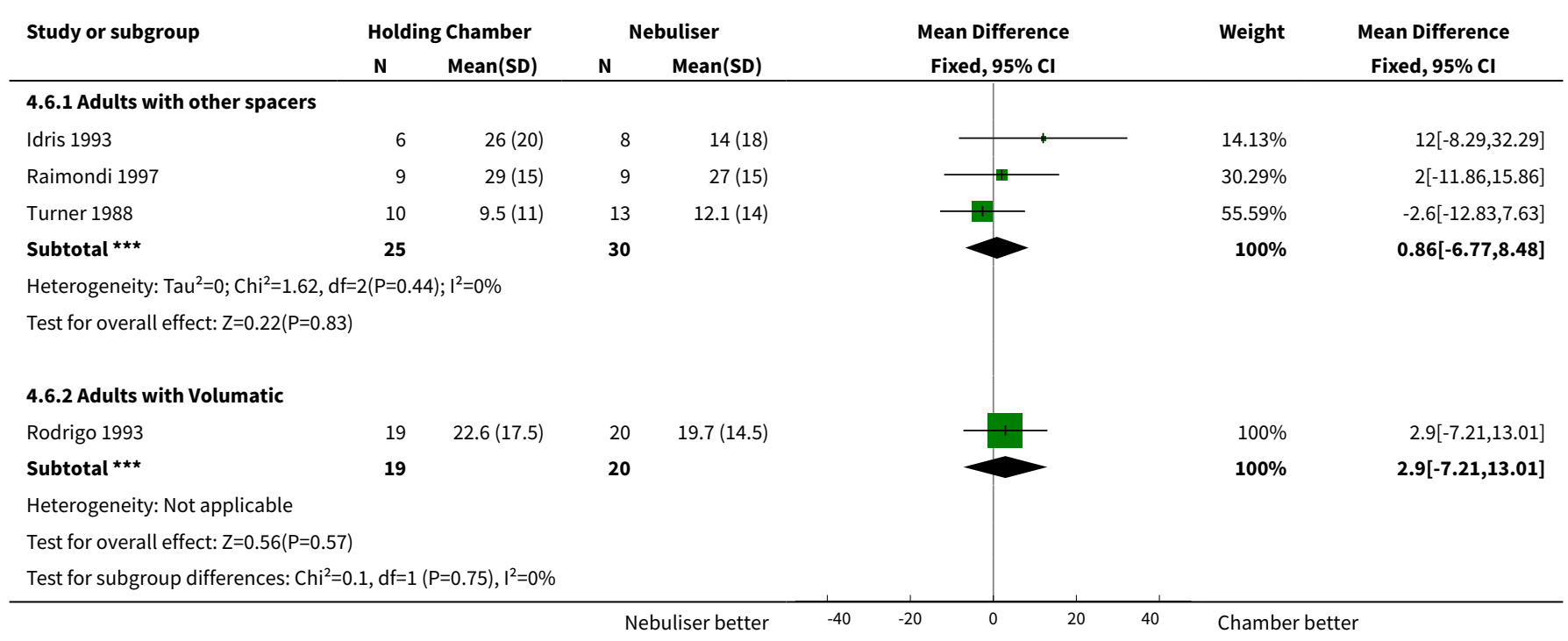


Analysis 4.7. Comparison 4 Spacer (chamber) versus nebuliser (multiple-treatment studies with Volumatic subgroups), Outcome 7 Final rise in peak flow (\% predicted).

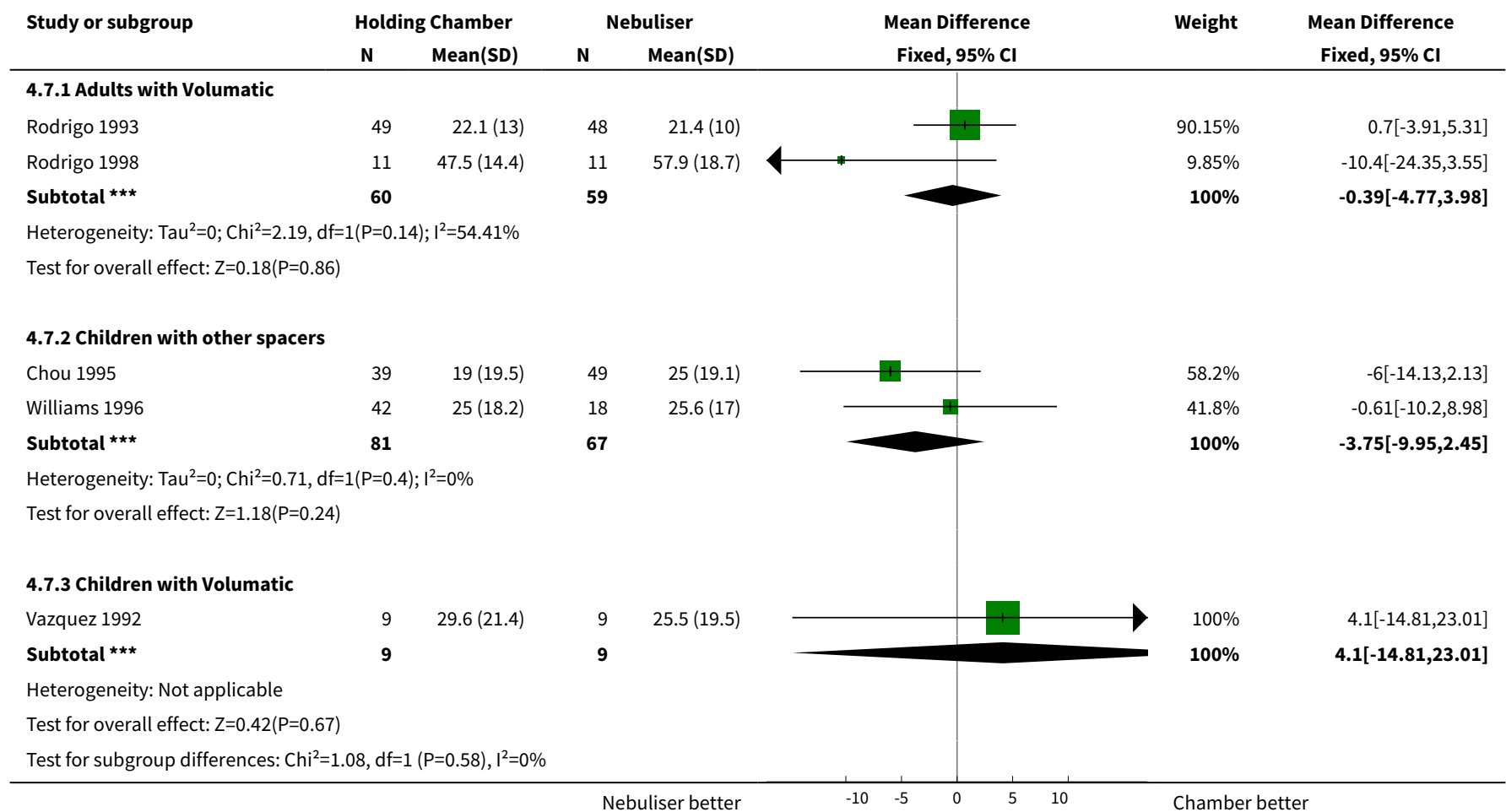

Analysis 4.8. Comparison 4 Spacer (chamber) versus nebuliser (multiple-treatment studies with Volumatic subgroups), Outcome 830 minute rise in peak flow (\% predicted).

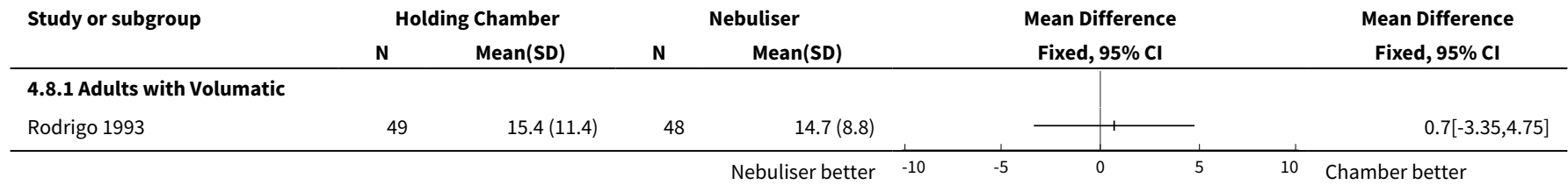

\section{Analysis 4.9. Comparison 4 Spacer (chamber) versus nebuliser (multiple-treatment} studies with Volumatic subgroups), Outcome 9 Rise in pulse rate (\% baseline).

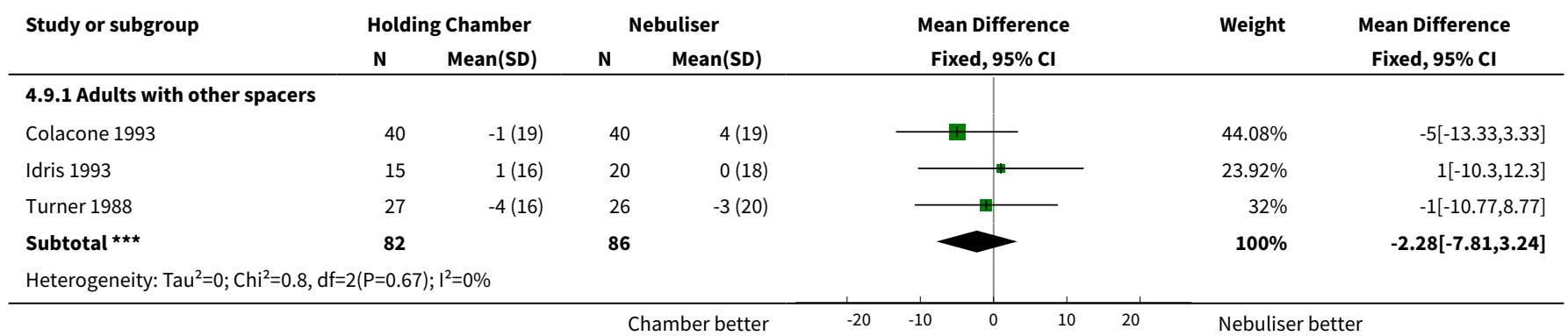




\begin{tabular}{|c|c|c|c|c|c|c|c|}
\hline \multirow[t]{2}{*}{ Study or subgroup } & \multicolumn{2}{|c|}{ Holding Chamber } & \multicolumn{2}{|c|}{ Nebuliser } & \multirow{2}{*}{$\begin{array}{c}\text { Mean Difference } \\
\text { Fixed, } 95 \% \mathrm{Cl}\end{array}$} & \multirow[t]{2}{*}{ Weight } & \multirow{2}{*}{$\begin{array}{c}\text { Mean Difference } \\
\text { Fixed, } 95 \% \mathrm{Cl}\end{array}$} \\
\hline & $\mathbf{N}$ & $\operatorname{Mean}(S D)$ & $\mathbf{N}$ & $\operatorname{Mean}(S D)$ & & & \\
\hline \multicolumn{5}{|c|}{ Test for overall effect: $Z=0.81(P=0.42)$} & & & \\
\hline \multicolumn{8}{|c|}{ 4.9.2 Adults with Volumatic } \\
\hline Rodrigo 1993 & 49 & $-1.3(13.8)$ & 48 & $-0.4(14.2)$ & +1 & $44.91 \%$ & $-0.88[-6.45,4.69]$ \\
\hline Rodriguez 1999 & 36 & $0(11.7)$ & 33 & $-1.3(10.7)$ & 1 & $49.94 \%$ & $1.3[-3.99,6.59]$ \\
\hline Subtotal $* \star \star$ & 96 & & 92 & & & $100 \%$ & $-0.16[-3.89,3.58]$ \\
\hline \multicolumn{8}{|c|}{ Heterogeneity: $\mathrm{Tau}^{2}=0 ; \mathrm{Chi}^{2}=1.23, \mathrm{df}=2(\mathrm{P}=0.54) ; \mathrm{I}^{2}=0 \%$} \\
\hline \multicolumn{8}{|c|}{ Test for overall effect: $Z=0.08(P=0.93)$} \\
\hline \multicolumn{8}{|c|}{ 4.9.3 Children with other spacers } \\
\hline Chou 1995 & 71 & $5(12.4)$ & 81 & $15(17.3)$ & $\longrightarrow$ & $24.36 \%$ & $-10[-14.74,-5.26]$ \\
\hline Duarte 2002 & 34 & $15(20.7)$ & 38 & $20(18.1)$ & & $6.73 \%$ & $-5[-14.03,4.03]$ \\
\hline Jamalvi 2006 & 84 & $-18(16.4)$ & 66 & $-17(15.7)$ & & $20.58 \%$ & $-1[-6.16,4.16]$ \\
\hline Leversha 2000 & 30 & $0.1(7.2)$ & 30 & $7.3(7.2)$ & $=$ & $41.3 \%$ & $-7.15[-10.79,-3.51]$ \\
\hline 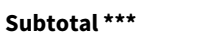 & 239 & & 225 & & & $100 \%$ & $-6.8[-9.14,-4.45]$ \\
\hline \multicolumn{8}{|c|}{ Heterogeneity: $\mathrm{Tau}^{2}=0 ; \mathrm{Chi}^{2}=8.28, \mathrm{df}=4(\mathrm{P}=0.08) ; \mathrm{I}^{2}=51.67 \%$} \\
\hline \multicolumn{8}{|c|}{ Test for overall effect: $Z=5.69(P<0.0001)$} \\
\hline \multicolumn{8}{|c|}{ 4.9.4 Children with Volumatic } \\
\hline Batra 1997 & 30 & $-12.8(9.4)$ & 30 & $-7.4(11.6)$ & & $71.03 \%$ & $-5.4[-10.74,-0.06]$ \\
\hline Vazquez 1992 & 9 & $-10(10)$ & 9 & $0(8)$ & & $28.97 \%$ & $-10[-18.37,-1.63]$ \\
\hline Subtotal $\star \star \star ~$ & 39 & & 39 & & & $100 \%$ & $-6.73[-11.24,-2.23]$ \\
\hline \multicolumn{8}{|c|}{ Heterogeneity: $\operatorname{Tau}^{2}=0 ; \mathrm{Chi}^{2}=0.82, \mathrm{df}=1(\mathrm{P}=0.36) ; \mathrm{I}^{2}=0 \%$} \\
\hline
\end{tabular}

\section{ADDITIONAL TABLES}




\begin{tabular}{|c|c|c|c|c|c|c|c|}
\hline Study ID & Spacer Type & $\begin{array}{l}\text { Spacer Vol- } \\
\text { ume }(\mathrm{mL})\end{array}$ & Adults of Children & $\begin{array}{l}\text { Number of } \\
\text { subjects }\end{array}$ & $\begin{array}{l}\text { Multiple or Single } \\
\text { Treatments }\end{array}$ & Location & Study design \\
\hline Ba 1989 & Nebuhaler & 750 & Children & 27 & Multiple & Inpatients & Double dummy \\
\hline Batra 1997 & Volumatic & 750 & Children & 60 & Multiple & Casualty & Open \\
\hline Burrows 2004 & Volumatic & 750 & Children & 29 & Multiple & Inpatients & Open \\
\hline $\begin{array}{l}\text { Chong-Neto } \\
2005\end{array}$ & $\begin{array}{l}\text { Aerochamber and home- } \\
\text { made }\end{array}$ & 145 or 500 & Children & 30 & Multiple & Community & $\begin{array}{l}\text { Dummy dry pow- } \\
\text { der given to spacer } \\
\text { group }\end{array}$ \\
\hline Chou 1995 & Aerochamber & 145 & Children & 152 & Multiple & Casualty & Open \\
\hline Coker 1995 & Volumatic & 750 & Children & 24 & Multiple & Inpatients & Open \\
\hline $\begin{array}{l}\text { Colacone } \\
1993\end{array}$ & Aerochamber & 145 & Adults & 80 & Multiple & Casualty & Double-dummy \\
\hline Dewar 1999 & Volumatic & 750 & Children & 62 & Multiple & Inpatients & Open \\
\hline Dhuper 2008 & Lite Aire & 160 & Adults & 58 & Multiple & Casualty & Double-dummy \\
\hline $\begin{array}{l}\text { Direk- } \\
\text { watanachai } \\
2008\end{array}$ & Volumatic & 750 & Children & 145 & Multiple & $\begin{array}{l}\text { Casualty \& Outpatient } \\
\text { Clinic }\end{array}$ & Open \\
\hline Duarte 2002 & home-made & 500 & Children & 196 & Multiple & Casualty & Open \\
\hline Ferrés 1989 & unknown & 750 & Children & 100 & Single & Casualty & Open \\
\hline $\begin{array}{l}\text { Freelander } \\
1984\end{array}$ & Nebuhaler & 750 & Children & 28 & Single & Casualty & Open \\
\hline Hussein 2002 & "Large volume" & NS & Children & 60 & Single & Casualty & Open \\
\hline Idris 1993 & Inspirease & 650 & Adults & 35 & Multiple & Casualty & Double-dummy \\
\hline Jamalvi 2006 & Babyhaler & 350 & Children & 150 & Multiple & Casualty & Open \\
\hline Kerem 1993 & Volumatic & 750 & Children & 33 & Single & Casualty & Double-dummy \\
\hline
\end{tabular}




\begin{tabular}{|c|c|c|c|c|c|c|c|}
\hline Leversha 2000 & Aerochamber & 145 & Children & 60 & Multiple & Casualty & Double dummy \\
\hline Lin 1995 & Aerochamber & 145 & Children & 111 & Single & Casualty & Open \\
\hline Maldano 1997 & unknown & NS & Children & 42 & Multiple & Casualty & Open \\
\hline Morley 1988 & Inspirease & 650 & Adults & 28 & Multiple & Inpatients & Open \\
\hline Morrone 1990 & unknown & 500 & Adults & 44 & Single & Community & Open \\
\hline Parkin 1995 & Aerochamber & 145 & Children & 65 & Multiple & Inpatients & Open \\
\hline $\begin{array}{l}\text { Pendergast } \\
1989\end{array}$ & Nebuhaler & 750 & Children & 27 & Multiple & Casualty & Open \\
\hline Ploin 2000 & Babyhaler & 350 & Children & 64 & Multiple & Casualty & Double-dummy \\
\hline $\begin{array}{l}\text { Raimondi } \\
1997\end{array}$ & Aerochamber & 145 & Adults & 27 & Multiple & Casualty & Open \\
\hline Rao 2002 & unknown & NS & Adults & 50 & Multiple & Casualty & Double-dummy \\
\hline $\begin{array}{l}\text { Robertson } \\
1998\end{array}$ & Volumatic & 750 & Children & 155 & Single & Casualty & Double-dummy \\
\hline Rodrigo 1993 & Volumatic & 750 & Adults & 97 & Multiple & Casualty & Double-dummy \\
\hline Rogrigo 1998 & Volumatic & 750 & Adults & 22 & Multiple & Casualty & Double-dummy \\
\hline $\begin{array}{l}\text { Rodriguez } \\
1999\end{array}$ & Volumatic & 750 & Adults & 69 & Multiple & Casualty & Open \\
\hline Salzman 1989 & Aerochamber & 145 & Adults & 44 & Single & Casualty & Double-dummy \\
\hline Sannier 2007 & $\begin{array}{l}\text { Varied according to child's } \\
\text { home use }\end{array}$ & NS & Children & 79 & Multiple & Casualty & Open \\
\hline Turner 1988 & Inspirease & 650 & Adults & 53 & Multiple & Casualty & Double-dummy \\
\hline Valencia 1999 & home-made & 500 & Children & 70 & Multiple & Casualty & Open \\
\hline Vazquez 1992 & Volumatic & 750 & Children & 18 & Multiple & Casualty & Open \\
\hline
\end{tabular}




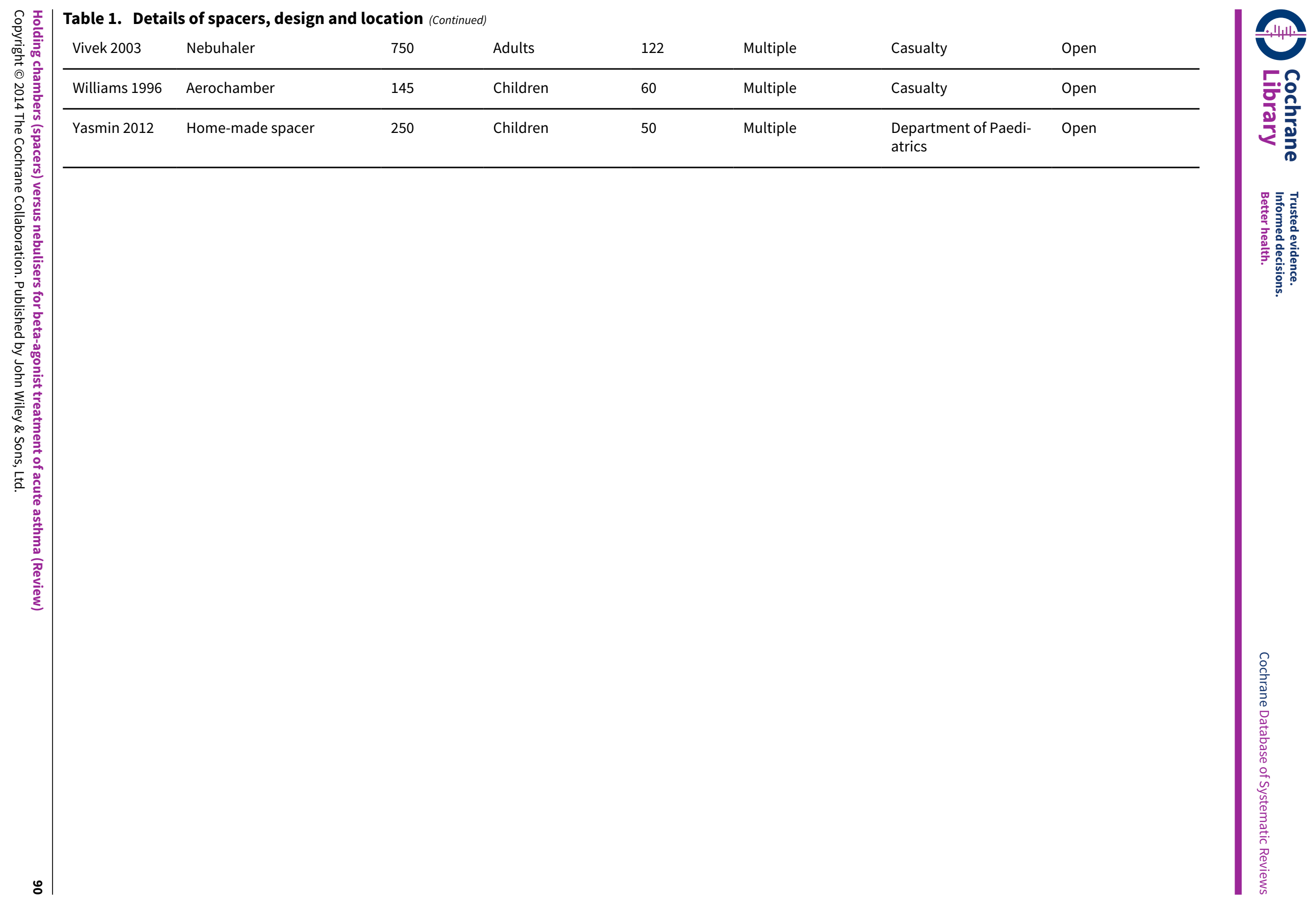




\section{APPENDICES}

\section{Appendix 1. Sources and search methods for the Cochrane Airways Group Specialised Register (CAGR)}

Electronic searches: core databases

\begin{tabular}{ll}
\hline Database & Frequency of search \\
\hline CENTRAL (the Cochrane Library) & Monthly \\
\hline MEDLINE (Ovid) & Weekly \\
\hline EMBASE (Ovid) & Weekly \\
\hline PSyCINFO (Ovid) & Monthly \\
\hline CINAHL (EBSCO) & Monthly \\
\hline AMED (EBSCO) & Monthly \\
\hline
\end{tabular}

Hand-searches: core respiratory conference abstracts

\begin{tabular}{ll}
\hline Conference & Years searched \\
\hline American Academy of Allergy, Asthma and Immunology (AAAAI) & 2001 onwards \\
\hline American Thoracic Society (ATS) & 2001 onwards \\
\hline Asia Pacific Society of Respirology (APSR) & 2004 onwards \\
\hline British Thoracic Society Winter Meeting (BTS) & 2000 onwards \\
\hline Chest Meeting & 2003 onwards \\
\hline European Respiratory Society (ERS) & $1992,1994,2000$ onwards \\
\hline International Primary Care Respiratory Group Congress (IPCRG) & 2002 onwards \\
\hline Thoracic Society of Australia and New Zealand (TSANZ) & 1999 onwards \\
\hline
\end{tabular}

\section{MEDLINE search strategy used to identify trials for the CAGR}

\section{Asthma search}

1. exp Asthma/

2. asthma\$.mp.

3. (antiasthma\$ or anti-asthma\$).mp. 
4. Respiratory Sounds/

5. wheez\$.mp.

6. Bronchial Spasm/

7. bronchospas\$.mp.

8. (bronch\$ adj3 spasm\$).mp.

9. bronchoconstrict\$.mp.

10. exp Bronchoconstriction/

11. (bronch\$ adj3 constrict\$).mp.

12. Bronchial Hyperreactivity/

13. Respiratory Hypersensitivity/

14. ((bronchial\$ or respiratory or airway $\$$ or lung\$) adj3 (hypersensitiv\$ or hyperreactiv\$ or allerg\$ or insufficiency)).mp.

15. ((dust or mite\$) adj3 (allerg\$ or hypersensitiv\$)).mp.

16. or/1-15

\section{Filter to identify RCTs}

1. exp "clinical trial [publication type]"/

2. (randomised or randomised).ab,ti.

3. placebo.ab,ti.

4. dt.fs.

5. randomly.ab,ti.

6. trial.ab,ti.

7. groups.ab,ti.

8. or/1-7

9. Animals/

10. Humans/

11. 9 not (9 and 10)

12. 8 not 11

The MEDLINE strategy and RCT filter are adapted to identify trials in other electronic databases.

\section{WHAT'S NEW}

\begin{tabular}{lll}
\hline Date & Event & Description \\
\hline 30 June 2014 & Amended & $\begin{array}{l}\text { The studies excluded life-threatening asthma, and this was } \\
\text { added to the abstract. }\end{array}$ \\
\hline
\end{tabular}

\section{H I S T O R Y}

Protocol first published: Issue 2, 1996 


\begin{tabular}{lll}
\hline Date & Event & Description \\
\hline 9 May 2014 & Amended & $\begin{array}{l}\text { Amended a sentence in the conclusion to make it clearer that "in } \\
\text { most cases nebulisers could be replaced with spacers to deliv- } \\
\text { er beta } \\
\text { fromonists in acute asthma" after receiving a suggestion }\end{array}$ \\
& & \begin{tabular}{l} 
frés Infante Llanos. Thanks Andrés. \\
\hline
\end{tabular} \\
\hline
\end{tabular}

\begin{tabular}{lll}
\hline 4 November $2013 \quad$ Amended & $\begin{array}{l}\text { Typos corrected. Changed LABA to SABA in the discussion and } \\
\text { expanded an occurence of LABA to beta } 2 \text {-agonists. }\end{array}$
\end{tabular}

\begin{tabular}{lll}
\hline 14 February 2013 & New search has been performed & Literature search run \\
\hline \multirow{2}{*}{14 February 2013 } & New citation required and conclusions & Four further new studies including 58 adults and 295 children \\
& have changed & 1989 (single treatment); Yasmin 2012). Also individual patient da- \\
& & ta has been incorporated from Burrows 2004 for children over 2 \\
& years of age treated as inpatients.
\end{tabular}

Two 'Summary of findings' Tables have been added. We also completed a new 'Risk of bias' assessment using the Review Manager 5 tool. Conclusions have been changed to emphasise the use of repeated treatments titrated to the participant's response in the trials.

\begin{tabular}{|c|c|c|}
\hline 28 July 2008 & New search has been performed & $\begin{array}{l}\text { Converted to new review format and two new studies added (Ja- } \\
\text { malvi } 2006 \text { and Sannier 2007). No change in conclusions. }\end{array}$ \\
\hline 4 January 2006 & New search has been performed & $\begin{array}{l}\text { For the } 2006 \text { update of this review five new trials have been } \\
\text { added: Burrows } 2004 \text { including } 29 \text { paediatric in-patients, Chong- } \\
\text { Neto } 2005 \text { included } 30 \text { children given multiple treatments, Hus- } \\
\text { sein } 2002 \text { including } 60 \text { children given a single treatment, Rao } \\
2002 \text { including } 50 \text { adults given multiple treatments and Vivek } \\
2003 \text { including } 120 \text { patients aged 10-50 (and therefore classified } \\
\text { as adult) given multiple treatments. } \\
\text { An additional table has been added with details of the holding } \\
\text { chambers used in each study, and new comparisons added ac- } \\
\text { cording to type of chamber. This was done because Volumatic } \\
\text { spacers were no longer being manufactured (but they have now } \\
\text { been reintroduced). }\end{array}$ \\
\hline
\end{tabular}

29 July $2003 \quad$ New search has been performed

\begin{abstract}
One trial was added to the review in 1997 (Williams 1996). Four further trials were added to the review in 1999 (Batra 1997; Maldano-Alanis 1997; Robertson 1998; Rodrigo 1998), but the conclusions of the review remained unchanged. For the 2001 update a further four studies were added (Leversha 2000; Ploin 2000; Rodriguez 1999; Valencia 1999) and reduced the confidence intervals around the results.

One open trial in children has been added for the 2003 update (Duarte 2002) including a further 196 children studied in an emergency room setting in Brazil.

In addition the 2003 update has expanded the review to include trials on in-patients and five new trials have been added including 184 children and 28 adults (Ba 1989, Coker 1995, Dewar 1999, Morley 1988 and Parkin 1995). The results of the in-patient trials are in keeping with the findings in the emergency room and community setting, that holding chambers can be as effective as nebulisers for delivery of beta-agonists in acute asthma.
\end{abstract}




\section{CONTRIBUTIONS OF AUTHORS}

CJC had the initial idea for the review and wrote the protocol and review in conjunction with BHR. The data extraction and analysis were performed by CJC and the methodological quality was independently assessed by Robert Chapman for the original papers. Anna Bara independently assessed trials for inclusion, and extracted trial data for the 1997,1999 and 2001 updates. JAC and CJC assessed trials for inclusion and extracted data for the 2003 and 2006 update (to include trials on inpatients). CJC and BHR have updated the review to include further trials in 1997, 1999 and 2001. CJC, JAC and BHR have carried out the 2003, 2006, 2008 updates, and CJC and BHR carried out the 2013 update with help from William Griffiths, who independently assessed risks of bias and outcome data. EJW drafted the summary of findings table, contributed to discussion during the 2013 update and commented critically on the paper.

\section{DECLARATIONS OF INTEREST}

The authors have no financial interest in any of the devices used to deliver beta ${ }_{2}$-agonists in acute asthma and no involvement with the primary studies.

\section{SOURCES OF SUPPORT}

\section{Internal sources}

- NHS Executive, North Thames, UK.

- NHS Executive Eastern Region, UK.

- Department of Emergency Medicine, University of Alberta, Edmonton, Canada.

- St George's University of London, UK.

\section{External sources}

- Garfield Weston Foundation, UK.

- Canadian Institutes of Health Research (CIHR), Ottawa, Canada.

\section{DIFFERENCES BETWEEN PROTOCOLAND REVIEW}

We have now included studies on people who had been admitted to hospital, and we have used the Review Manager 5 'Risk of bias' tool and $\mathrm{I}^{2}$ statistics (which were not available when the original protocol was written).

\section{INDEX TERMS}

\section{Medical Subject Headings (MeSH)}

*Nebulizers and Vaporizers; Acute Disease; Adrenergic beta-Agonists [ ${ }^{*}$ administration \& dosage]; Anti-Asthmatic Agents [*administration \& dosage]; Asthma [ ${ }^{\star}$ drug therapy]; Emergency Service, Hospital [statistics \& numerical data]; Equipment Design; Inhalation Spacers [statistics \& numerical data]; Length of Stay [statistics \& numerical data]; Randomized Controlled Trials as Topic

\section{MeSH check words}

Adult; Child; Child, Preschool; Humans 